Supporting Information for the article

\title{
Synthesis of a Heterometallic Trinuclear Cluster of Ruthenium and Platinum with a Linear Alignment
}

Takuya Kuzutani $^{\dagger}$, Yushi Torihata ${ }^{\dagger}$, Hiroharu Suzuki ${ }^{\dagger}$, Toshiro Takao ${ }^{\dagger, \ddagger * *}$

${ }^{\dagger}$ Department of Chemical Science and Engineering, School of Materials and Chemical Technology, Tokyo Institute of Technology, 2-12-1 O-okayama, Meguro-ku, Tokyo 152-8552, Japan

${ }^{\ddagger}$ JST, ACT-C, 4-1-8 Honcho, Kawaguchi, Saitama 3332-0012, Japan

Contents

1. NMR and IR spectra

a. $\quad{ }^{1} \mathrm{H},{ }^{13} \mathrm{C}\left\{{ }^{1} \mathrm{H}\right\}$, and ${ }^{31} \mathrm{P}\left\{{ }^{1} \mathrm{H}\right\}$ NMR and IR spectra of $\left\{\mathrm{Cp} * \mathrm{Ru}(\mathrm{H})_{2}\right\}_{2} \mathrm{Pt}\left(\mu-\mathrm{P}^{\mathrm{t}} \mathrm{Bu}_{2}\right)_{2}(\mu-\mathrm{H})_{2}(2)$

b. $\quad{ }^{1} \mathrm{H},{ }^{13} \mathrm{C}\left\{{ }^{1} \mathrm{H}\right\}$, and ${ }^{31} \mathrm{P}\left\{{ }^{1} \mathrm{H}\right\}$ NMR and IR spectra of $(\mathrm{Cp} * \mathrm{Ru})_{2}\left\{\mathrm{Pt}\left(\mathrm{P}^{\mathrm{t} B u} \mathrm{Bu}_{2} \mathrm{H}\right)\right\}\left(\mu-\mathrm{P}^{\mathrm{t} B u} \mathrm{Bu}_{2}\right)(\mu-\mathrm{H})_{3}(\mathrm{H})_{2}$ (4)

c. The reaction of a mixture of $\mathrm{Cp} * \mathrm{Ru}(\mu-\mathrm{H})_{4} \mathrm{RuCp}^{*}(\mathbf{1})$ and ${ }^{\mathrm{Et}} \mathrm{CpRu}(\mu-\mathrm{H})_{4} \mathrm{Ru}^{\mathrm{Et}} \mathrm{Cp}\left(\mathbf{1}^{\prime}\right)$ with $\mathrm{Pt}\left(\mathrm{Pt}^{\mathrm{t}} \mathrm{Bu}_{2} \mathrm{H}\right)_{3}$.

d. $\quad{ }^{1} \mathrm{H},{ }^{13} \mathrm{C}\left\{{ }^{1} \mathrm{H}\right\}$, and ${ }^{31} \mathrm{P}\left\{{ }^{1} \mathrm{H}\right\}$ NMR and IR spectra of $\{\mathrm{Cp} * \mathrm{Ru}(\mathrm{CO})\}_{2} \mathrm{Pt}\left(\mu-\mathrm{P}^{\mathrm{t}} \mathrm{Bu}_{2}\right)_{2}(\mu-\mathrm{H})_{2}($ trans-5)

e. $\quad{ }^{1} \mathrm{H}$ and ${ }^{31} \mathrm{P}\left\{{ }^{1} \mathrm{H}\right\}$ NMR and IR spectra of the mixture of cis- and trans-5

f. $\quad{ }^{1} \mathrm{H}$ and ${ }^{31} \mathrm{P}\left\{{ }^{1} \mathrm{H}\right\}$ NMR and IR spectra of $\left\{\mathrm{Cp} * \mathrm{Ru}\left(\mathrm{C}_{2} \mathrm{H}_{4}\right)\right\}_{2} \mathrm{Pt}\left(\mu-\mathrm{P}^{\mathrm{t}} \mathrm{Bu}_{2}\right)_{2}(\mu-\mathrm{H})_{2}$ (cis- and trans-6)

g. $\quad{ }^{1} \mathrm{H}$ NMR spectra of $\left\{\mathrm{Cp} * \mathrm{Ru}(\mathrm{H})_{2}\right\}\left\{\mathrm{Cp} * \mathrm{Ru}\left(\mathrm{C}_{2} \mathrm{H}_{4}\right)\right\} \operatorname{Pt}\left(\mu-\mathrm{P}^{\mathrm{t} B u}\right)_{2}(\mu-\mathrm{H})_{2}(7)$

h. $\quad{ }^{1} \mathrm{H},{ }^{13} \mathrm{C}\left\{{ }^{1} \mathrm{H}\right\}$, and ${ }^{31} \mathrm{P}\left\{{ }^{1} \mathrm{H}\right\}$ NMR and IR spectra of $(\mathrm{Cp} * \mathrm{Ru})_{2} \operatorname{Pt}\left(\mu-\mathrm{P}^{\mathrm{t} B u}\right)_{2}(\mu-\mathrm{H})_{2}(\mathbf{8})$

i. $\quad{ }^{1} \mathrm{H}$ and ${ }^{31} \mathrm{P}\left\{{ }^{1} \mathrm{H}\right\}$ NMR of $(\mathrm{Cp} * \mathrm{Ru})\left\{\mathrm{Cp} * \mathrm{Ru}(\mathrm{H})_{2}\right\} \operatorname{Pt}\left(\mu-\mathrm{P}^{\mathrm{t}} \mathrm{Bu}_{2}\right)_{2}(\mu-\mathrm{H})_{2}(3)$

j. $\quad{ }^{1} \mathrm{H}$ and ${ }^{31} \mathrm{P}\left\{{ }^{1} \mathrm{H}\right\}$ NMR and IR spectra of $\{\mathrm{Cp} * \mathrm{Ru}(\mathrm{H})\}\left\{\mathrm{Cp} * \mathrm{Ru}\left(\mathrm{P}^{\mathrm{t} B u} \mathrm{Bu}_{2} \mathrm{H}\right)\right\} \operatorname{Pt}\left(\mu-\mathrm{P}^{\mathrm{t}} \mathrm{Bu}_{2}\right)\left(\mu-\mathrm{SiPh}_{2}\right)(\mu-$ $\mathrm{H})_{2}$ (cis- and trans-9)

k. ${ }^{1} \mathrm{H},{ }^{13} \mathrm{C}\left\{{ }^{1} \mathrm{H}\right\}$, and ${ }^{31} \mathrm{P}\left\{{ }^{1} \mathrm{H}\right\} \quad \mathrm{NMR}$ and IR spectra of $\left\{\mathrm{Cp} * \mathrm{Ru}(\mathrm{H})_{2}\right\}\left\{\mathrm{Cp} * \operatorname{Ru}\left(\mathrm{P}^{\mathrm{t} B u} \mathrm{H}_{2} \mathrm{H}\right)\right\} \mathrm{Pt}(\mu-$ $\left.\mathrm{P}^{\mathrm{t} B \mathrm{u}_{2}}\right)\left(\mu-\eta^{2}-\mathrm{SiEt}_{2}\right)(\mu-\mathrm{H})_{2}(\mathbf{1 0})$

2. Crystallographic data for 2, 4, trans-5, trans-6, 8', cis-9, and 10.

3. Results of the DFT calculations on $\mathbf{2 , 4}$, and the possible isomer of $\mathbf{4}$ (A in Scheme 4)
a. $\quad\left\{\mathrm{Cp} * \mathrm{Ru}(\mathrm{H})_{2}\right\}_{2} \mathrm{Pt}\left(\mu-\mathrm{P}^{\mathrm{t}} \mathrm{Bu}_{2}\right)_{2}(\mu-\mathrm{H})_{2}(\mathbf{2})$
b. $\quad(\mathrm{Cp} * \mathrm{Ru})_{2}\left\{\mathrm{Pt}^{\mathrm{t}}\left(\mathrm{P}^{\mathrm{B}} \mathrm{u}_{2} \mathrm{H}\right)\right\}\left(\mu-\mathrm{P}^{\mathrm{t}} \mathrm{Bu}_{2}\right)(\mu-\mathrm{H})_{3}(\mathrm{H})_{2}(4)$
c. $\quad(\mathrm{Cp} * \mathrm{Ru})_{2}\left\{\mathrm{Pt}\left(\mathrm{P}^{\mathrm{t} B u} \mathrm{~B}_{2} \mathrm{H}\right)\right\}\left(\mu-\mathrm{P}^{\mathrm{t} B u_{2}}\right)_{2}(\mu-\mathrm{H})_{3}(\mathrm{H})_{2}(\mathbf{A})$ 
1. NMR and IR spectra

a. ${ }^{1} \mathrm{H},{ }^{13} \mathrm{C}\left\{{ }^{1} \mathrm{H}\right\}$, and ${ }^{31} \mathrm{P}\left\{{ }^{1} \mathrm{H}\right\}$ NMR and IR spectra of $\left\{\mathrm{Cp} * \operatorname{Ru}(\mathrm{H})_{2}\right\}_{2} \mathrm{Pt}\left(\mu-\mathrm{P}^{t} \mathrm{Bu}_{2}\right)_{2}(\mu-\mathrm{H})_{2}(2)$

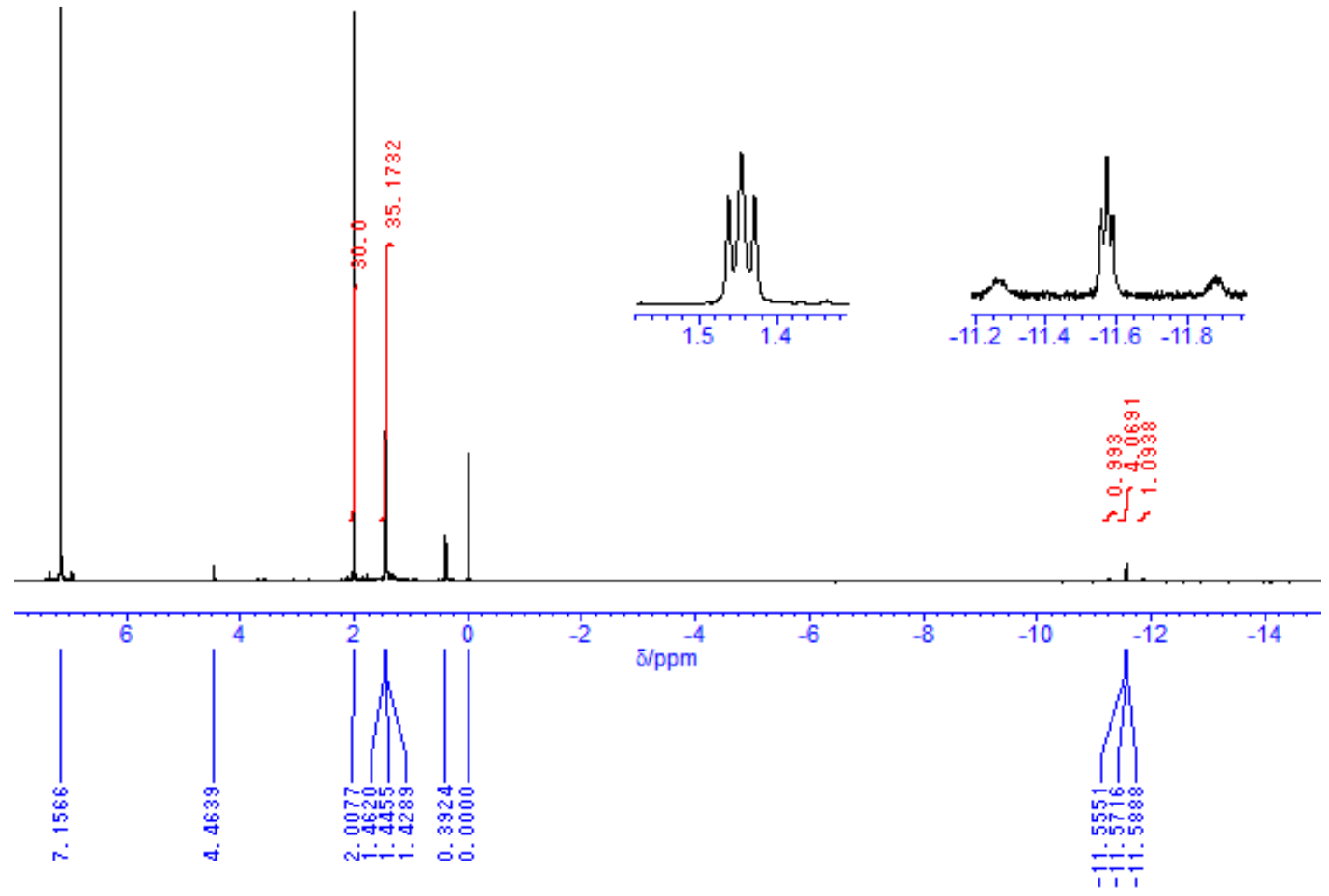

Figure S-1. ${ }^{1} \mathrm{H}$ NMR spectrum of $2\left(400 \mathrm{MHz}, \mathrm{C}_{6} \mathrm{D}_{6}, 25^{\circ} \mathrm{C}\right)$. The signal resonating at $\delta 4.46 \mathrm{ppm}$ was derived from $\mathrm{H}_{2}$ introduced in the NMR tube in order to prevent the decomposition of $\mathbf{2}$ into 3.

Table S-1. Obtained Parameters for the Curve-Fitting of the $t$-Bu Signal of 2

\begin{tabular}{|l|c|c|c|c|c|}
\hline & \multirow{2}{*}{$\begin{array}{c}\text { Nucleus } \\
\text { (number) }\end{array}$} & \multirow{2}{*}{$\delta / \mathrm{ppm}$} & \multirow{2}{*}{$\mathrm{W}(\mathrm{Hz})$} & \multicolumn{2}{|c|}{$J(\mathrm{~Hz})$} \\
\cline { 5 - 6 } & & & 1 & 2 \\
\hline 1 & ${ }^{1} \mathrm{H}(9)$ & 1.447 & 2.1 & --- & ---- \\
\hline 2 & ${ }^{31} \mathrm{P}(1)$ & 239.1 & 1.0 & 12.00 & ---- \\
\hline 3 & ${ }^{31} \mathrm{P}(1)$ & 239.1 & 1.0 & 1.00 & 100.00 \\
\hline
\end{tabular}
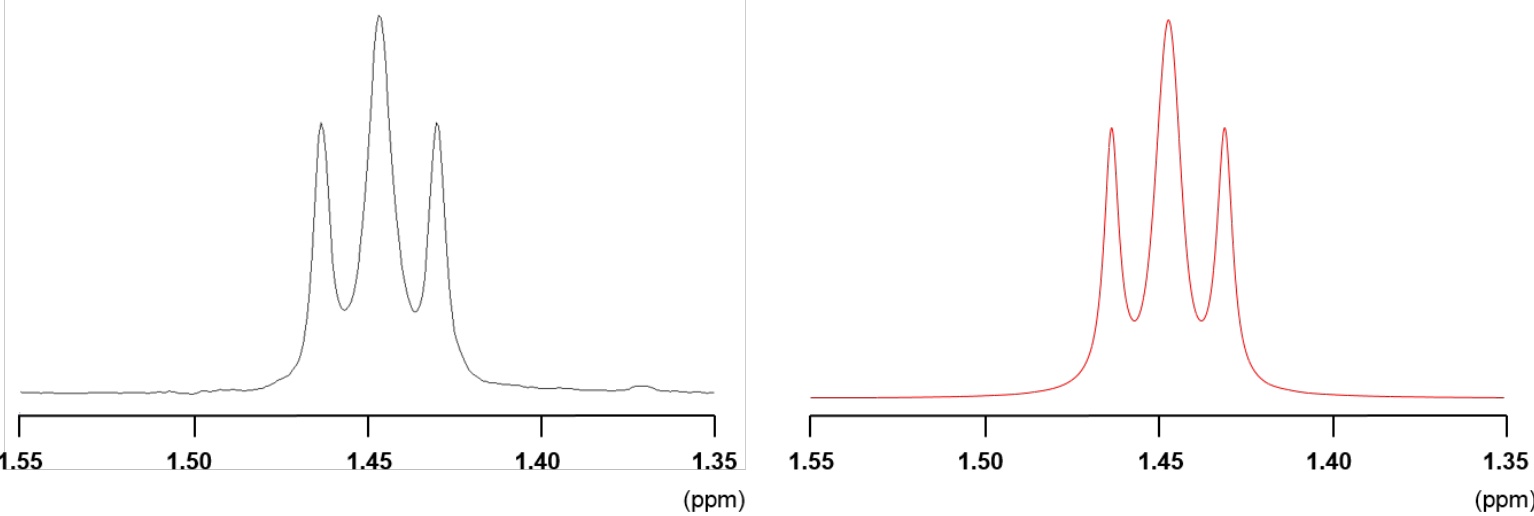

Figure S-2. The $t$-Bu signal of 2 recorded at $25^{\circ} \mathrm{C}\left(400 \mathrm{MHz}, \mathrm{C}_{6} \mathrm{D}_{6}\right.$; left) and the simulated signal obtained from the parameters listed in Table S-1 (right). 


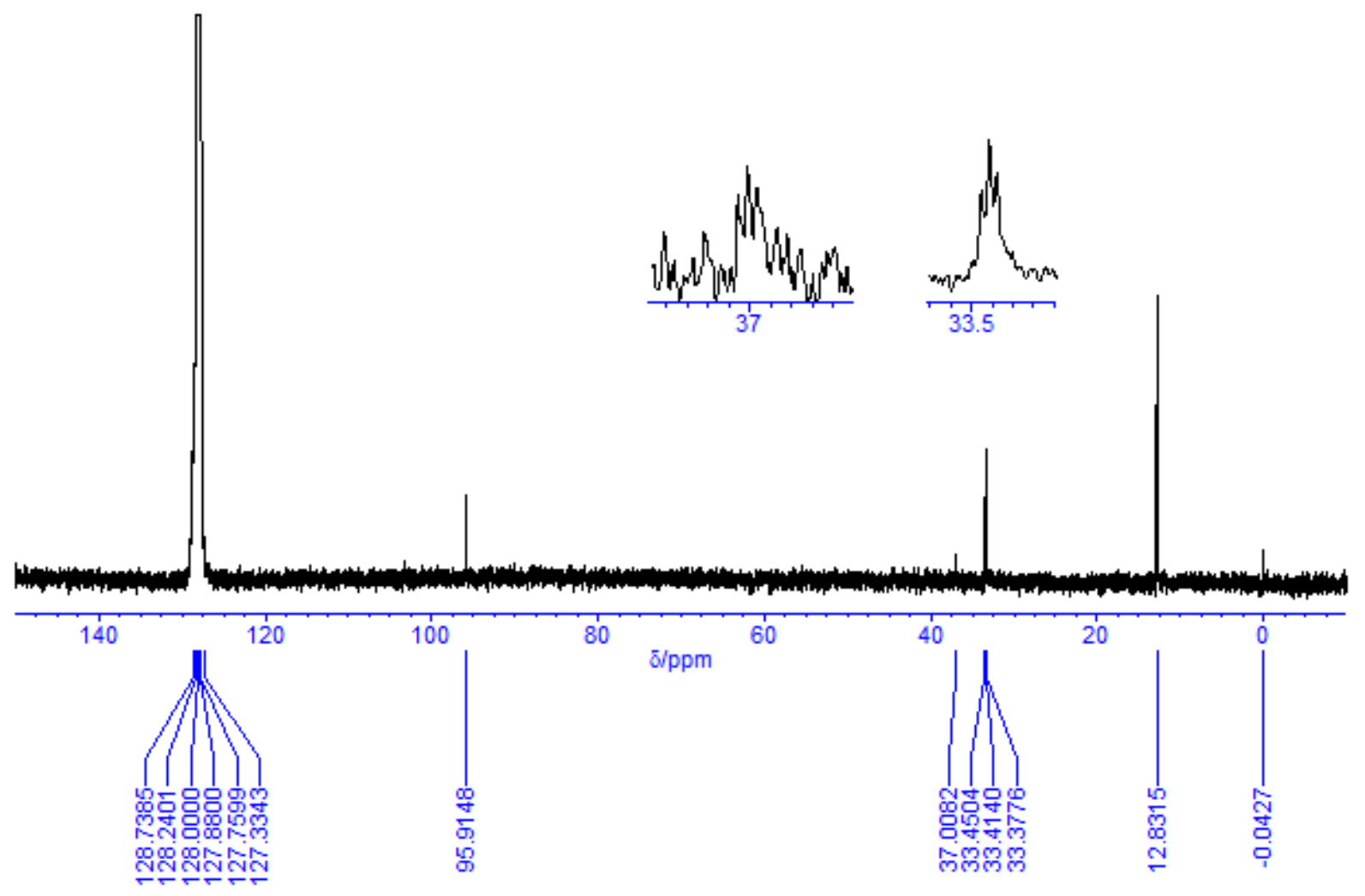

Figure S-3. ${ }^{13} \mathrm{C}\left\{{ }^{1} \mathrm{H}\right\}$ NMR spectrum of $2\left(100 \mathrm{MHz}, \mathrm{C}_{6} \mathrm{D}_{6}, 25^{\circ} \mathrm{C}\right)$.

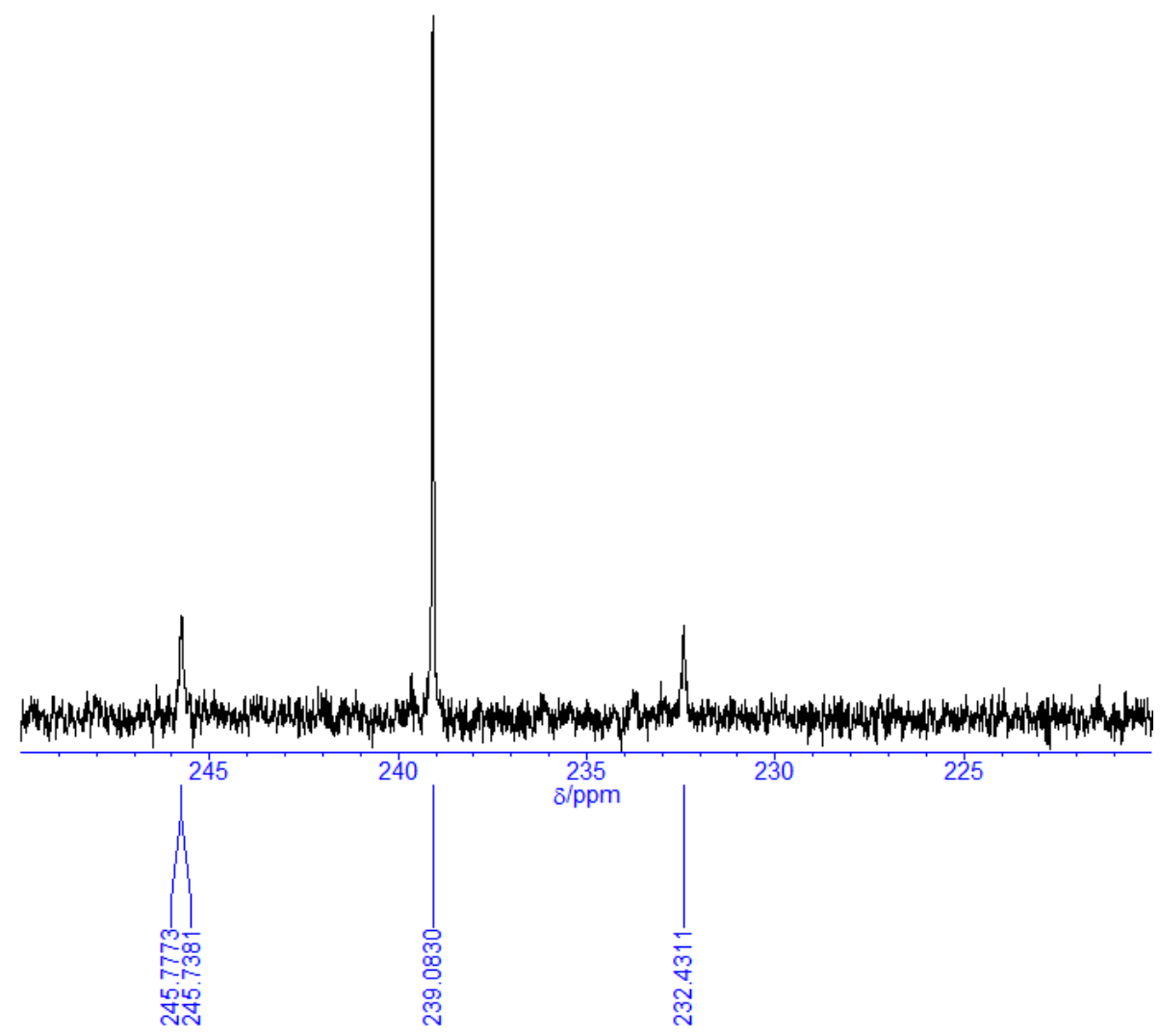

Figure S-4. ${ }^{31} \mathrm{P}\left\{{ }^{1} \mathrm{H}\right\}$ NMR spectrum of $2\left(162 \mathrm{MHz}, \mathrm{C}_{6} \mathrm{D}_{6}, 25^{\circ} \mathrm{C}\right)$. 


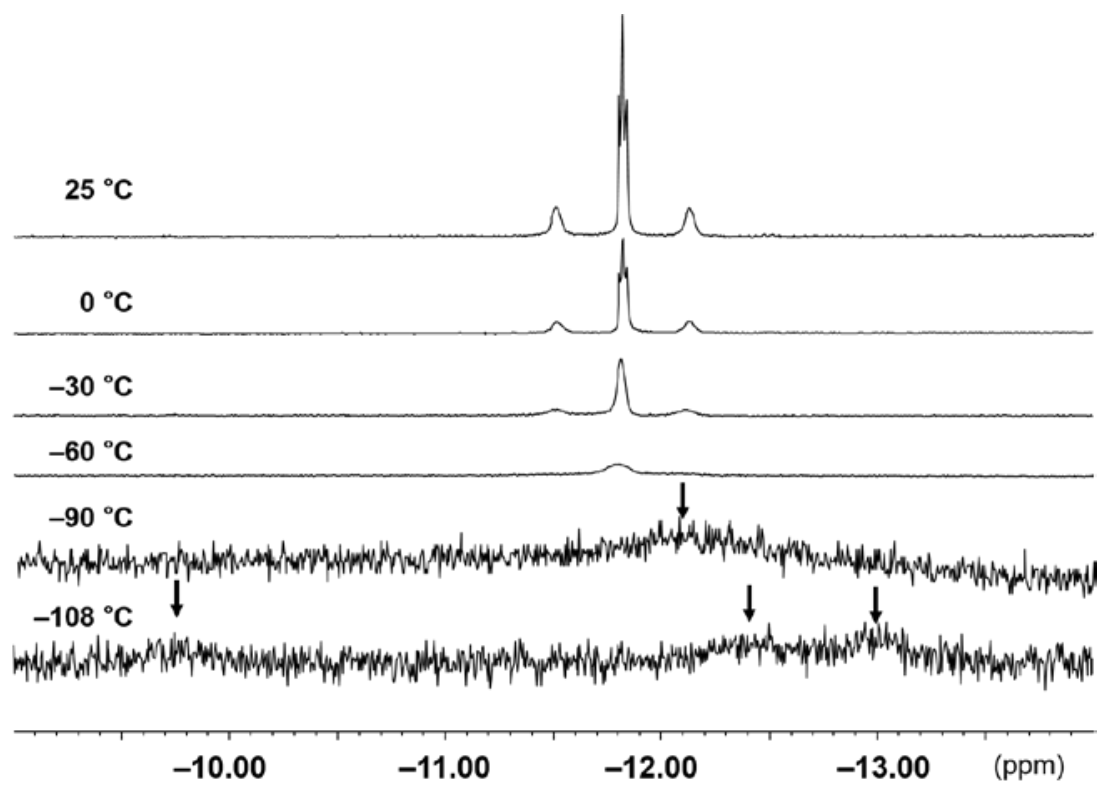

Figure S-5. Variable temperature ${ }^{1} \mathrm{H}$ NMR spectra of 2 showing hydrido region (400 MHz, THF- $d_{8}:$ toluene$\left.d_{8}=4: 1\right)$.

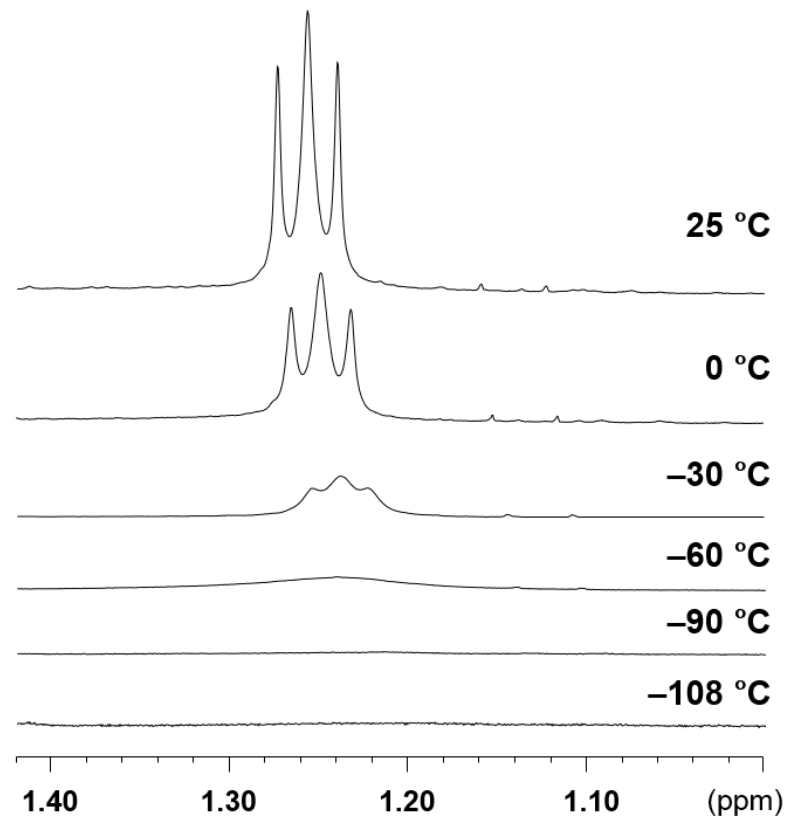

Figure S-6. Variable temperature ${ }^{1} \mathrm{H}$ NMR spectra of 2 showing $t$-Bu region (400 MHz, THF- $d_{8}$ :toluene- $d_{8}$ $=4: 1$. 


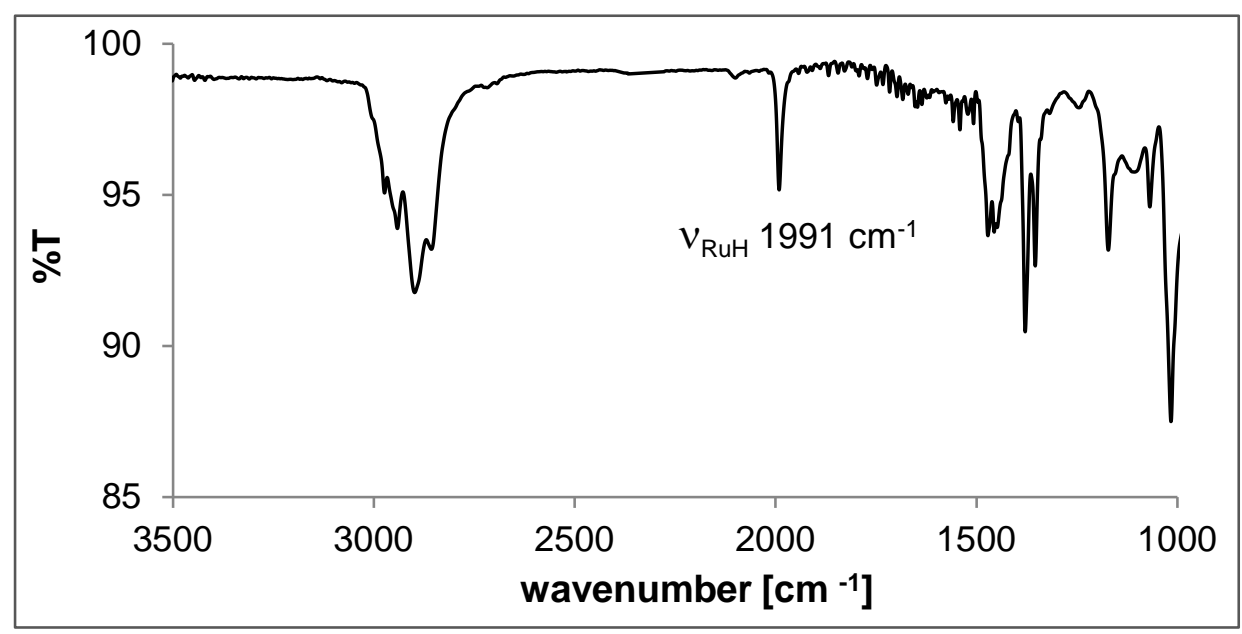

Figure S-7. IR spectrum of $2\left(\mathrm{ATR}, \mathrm{cm}^{-1}\right)$. 


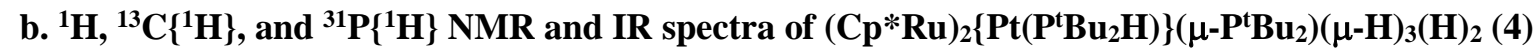

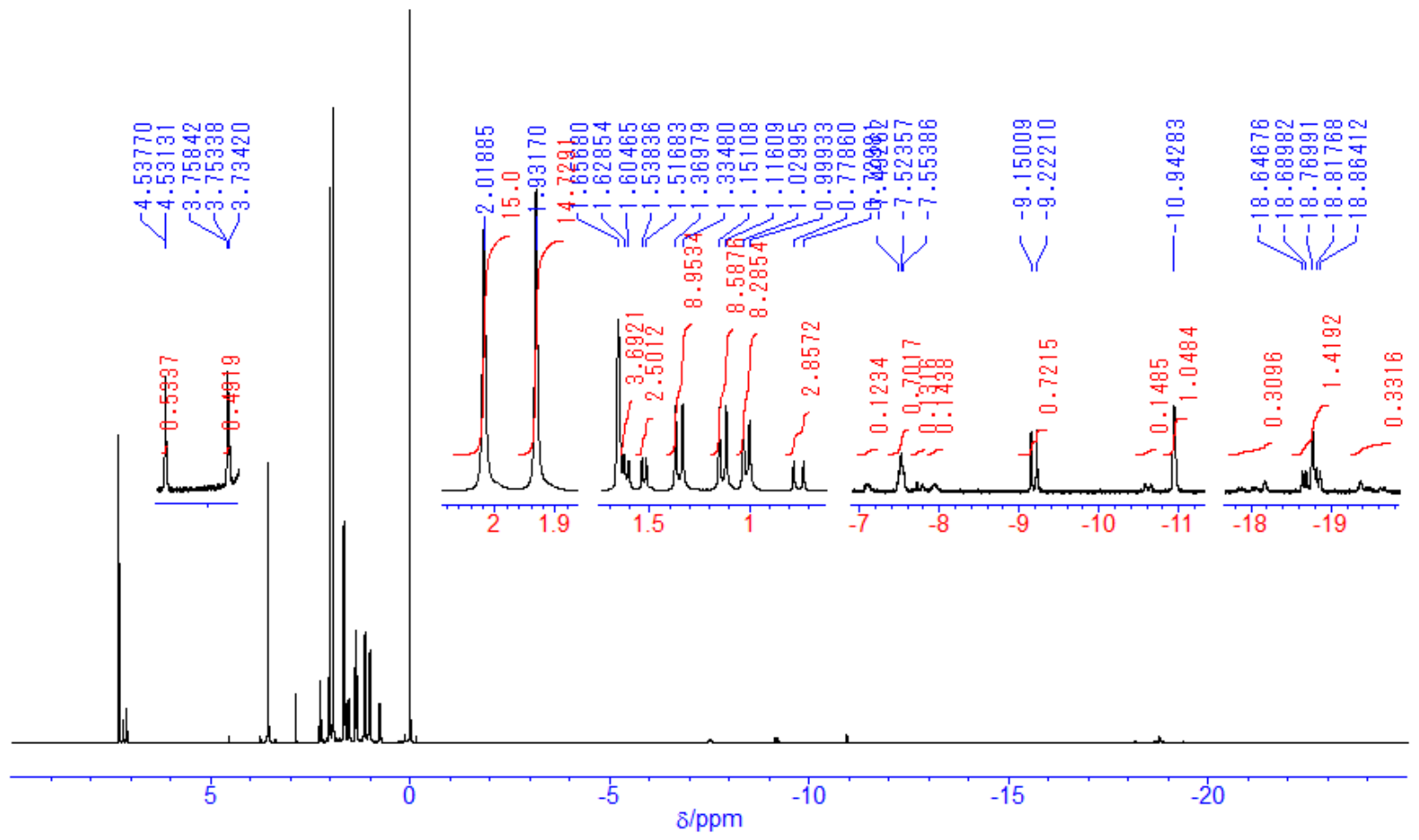

Figure S-8. ${ }^{1} \mathrm{H}$ NMR spectrum of $4\left(400 \mathrm{MHz}, 400 \mathrm{MHz}\right.$, THF- $d_{8} /$ toluene- $\left.d_{8}=4 / 1,-30{ }^{\circ} \mathrm{C}\right)$.

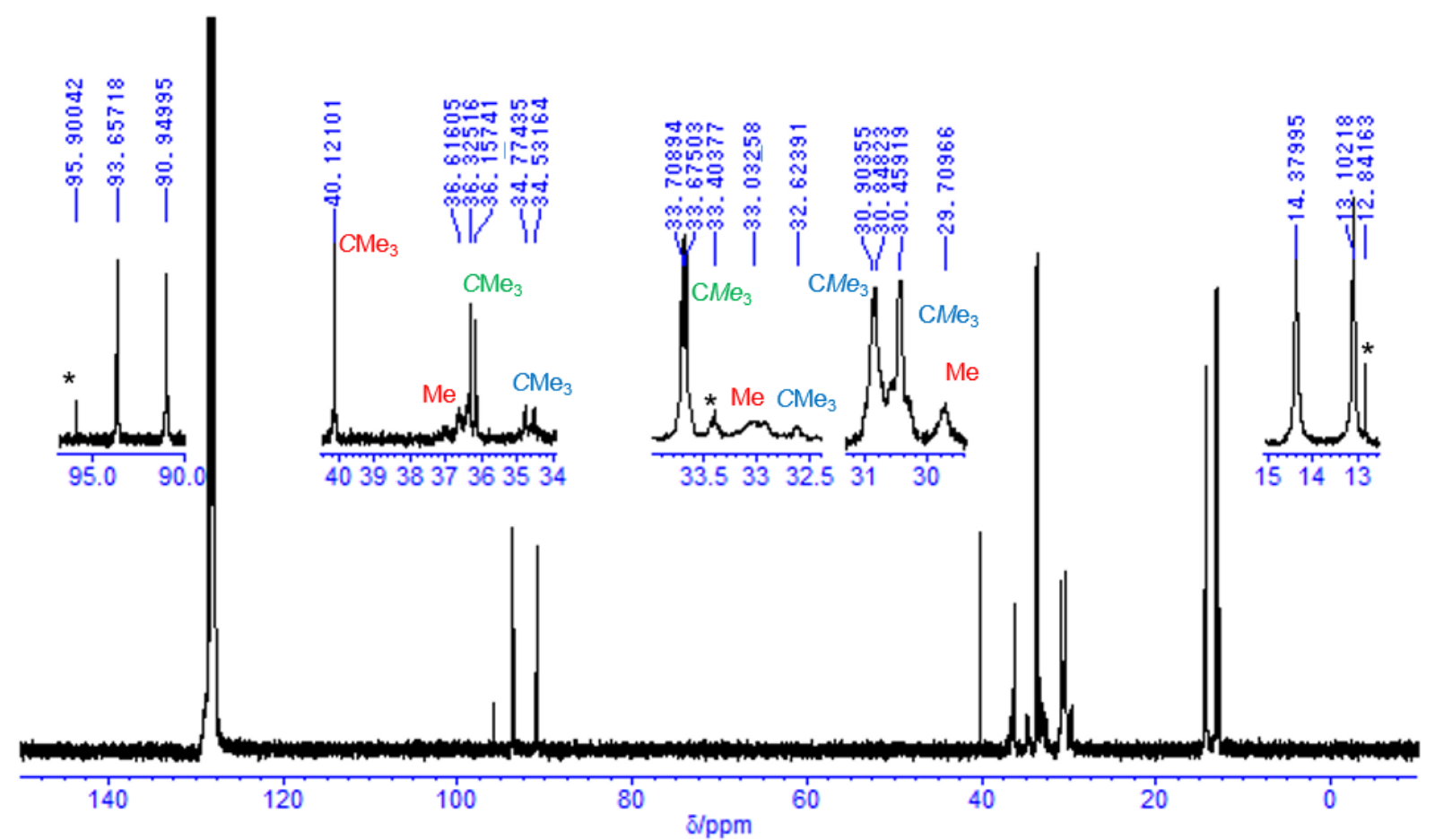

Figure S-9. ${ }^{13} \mathrm{C}\left\{{ }^{1} \mathrm{H}\right\}$ NMR spectrum of $4\left(100 \mathrm{MHz}, \mathrm{C}_{6} \mathrm{D}_{6}, 25^{\circ} \mathrm{C}\right)$. The signals marked with * were derived from 2. 


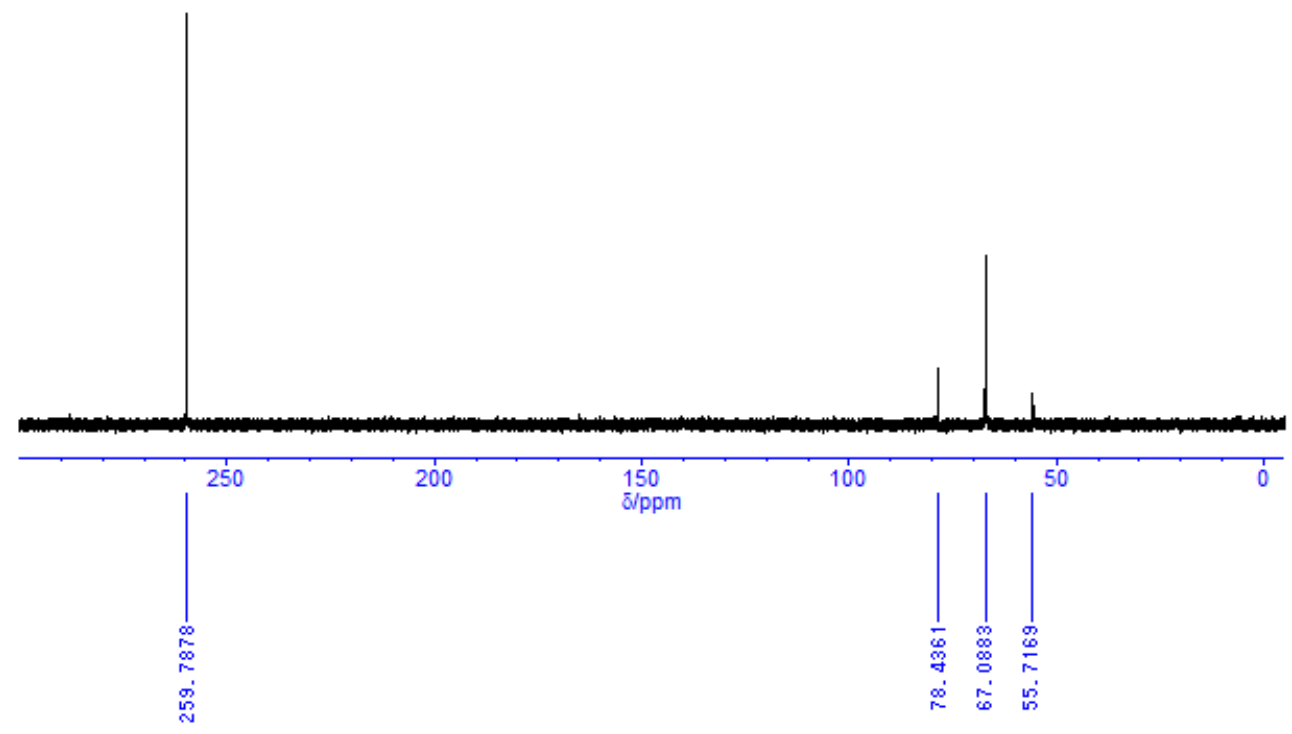

Figure S-10. ${ }^{31} \mathrm{P}\left\{{ }^{1} \mathrm{H}\right\}$ NMR spectrum of $4\left(162 \mathrm{MHz}, \mathrm{C}_{6} \mathrm{D}_{6}, 25^{\circ} \mathrm{C}\right)$.
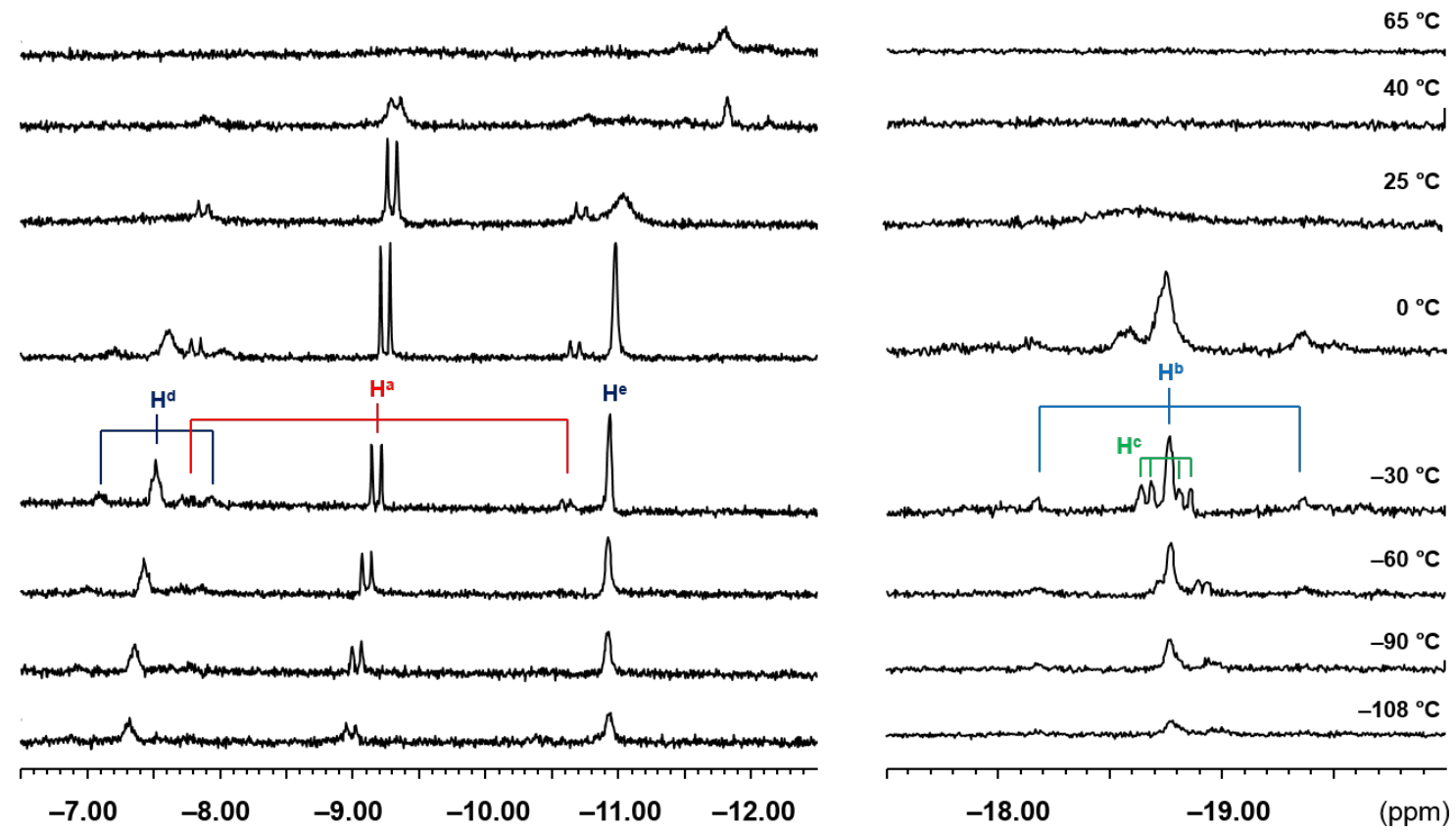

Figure S-11. Variable temperature ${ }^{1} \mathrm{H}$ NMR spectra of 4 showing hydrido region ( $400 \mathrm{MHz}$, THF- $\mathrm{d}_{8}$ :toluene$\left.d_{8}=4: 1\right)$.

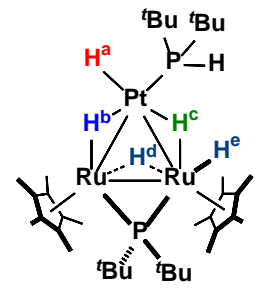




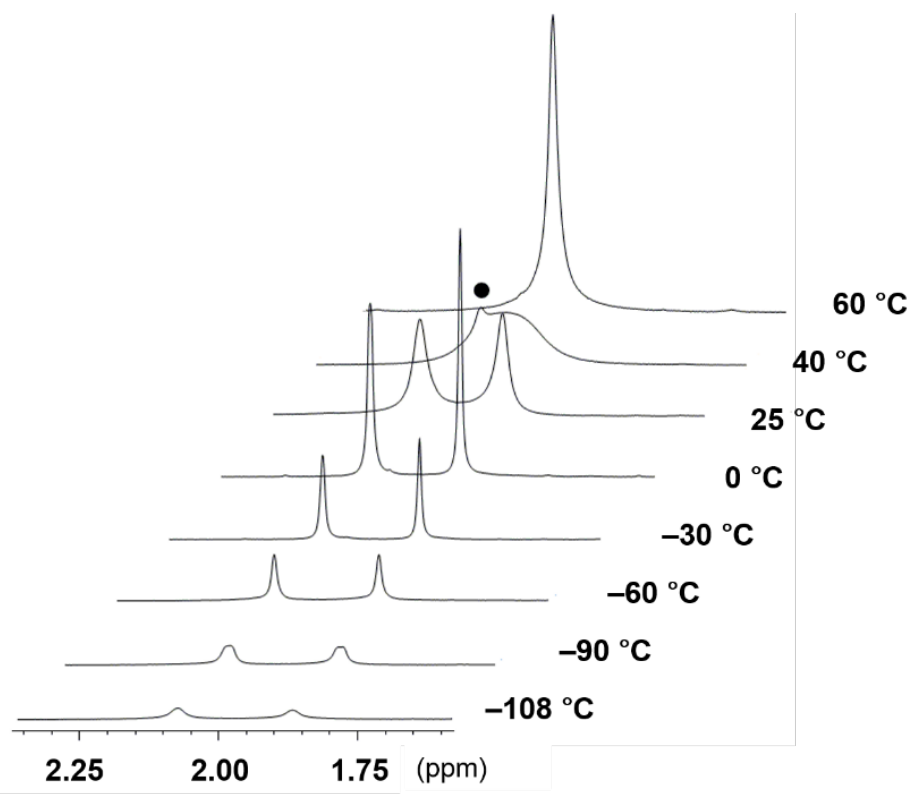

Figure S-12. Variable temperature ${ }^{1} \mathrm{H}$ NMR spectra of 4 showing Cp* region (400 MHz, THF- $d_{8}:$ toluene- $d_{8}$ = 4:1). The signal marked with $\bullet$ was the $\mathrm{Cp}^{*}$ signal derived from contaminated 2 .

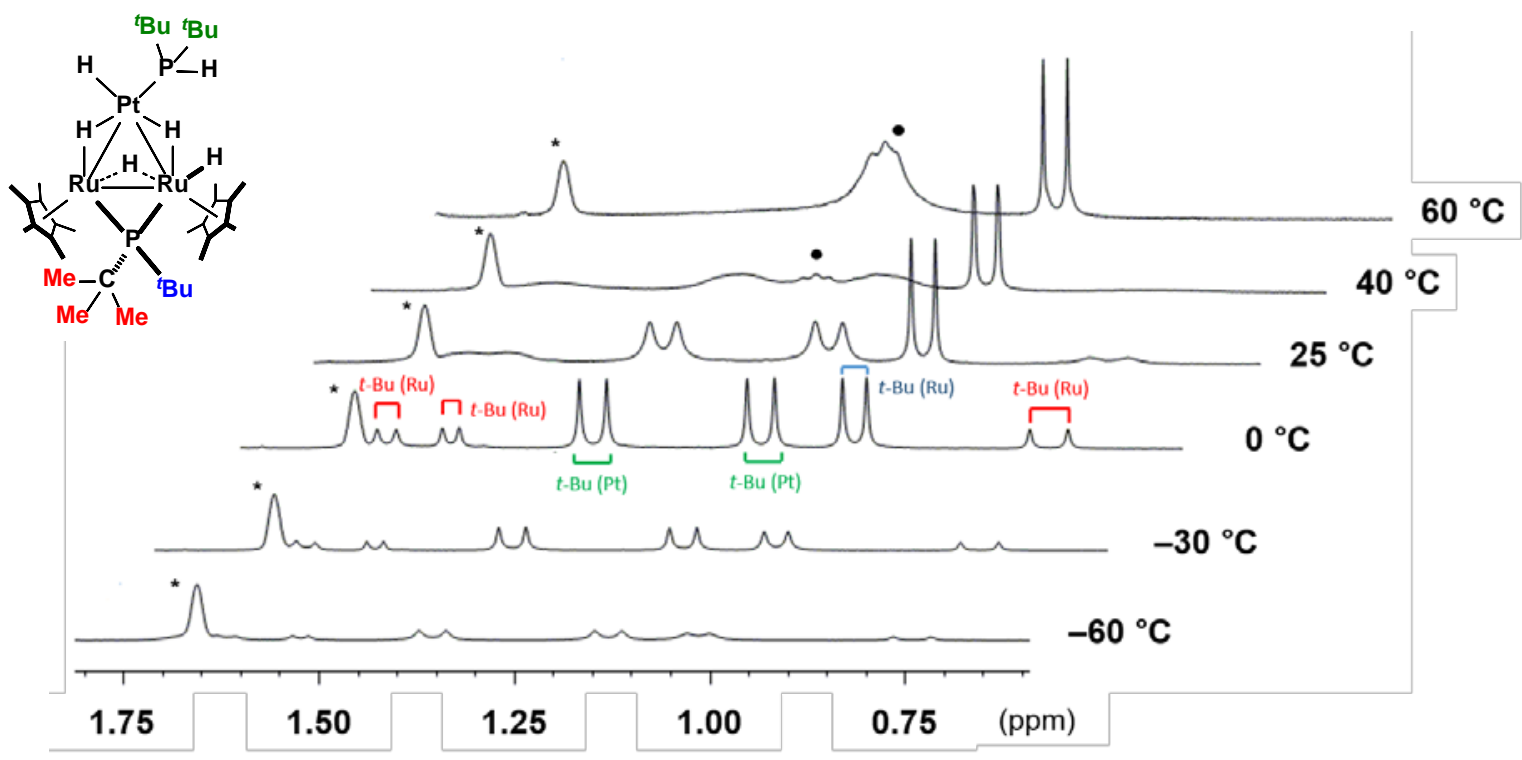

Figure S-13. Variable temperature ${ }^{1} \mathrm{H}$ NMR spectra of 4 showing $t$-Bu region (400 MHz, THF- $d_{8}:$ toluene- $d_{8}$ $=4: 1$ ). The signal marked with $\bullet$ was the $t$-Bu signal derived from 2 generated in situ, and the signal marked with * was residual proton of THF- $d_{8}$. 
(a)

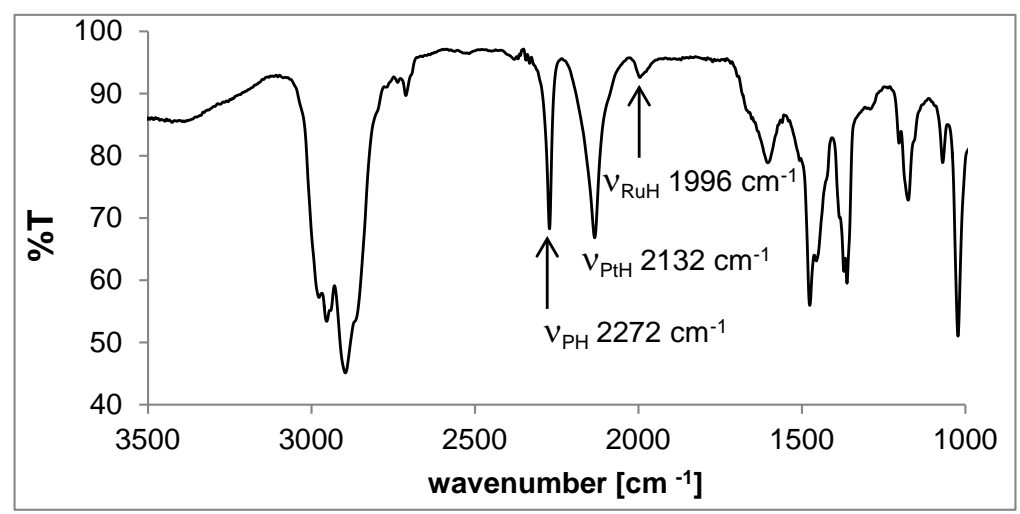

(b)

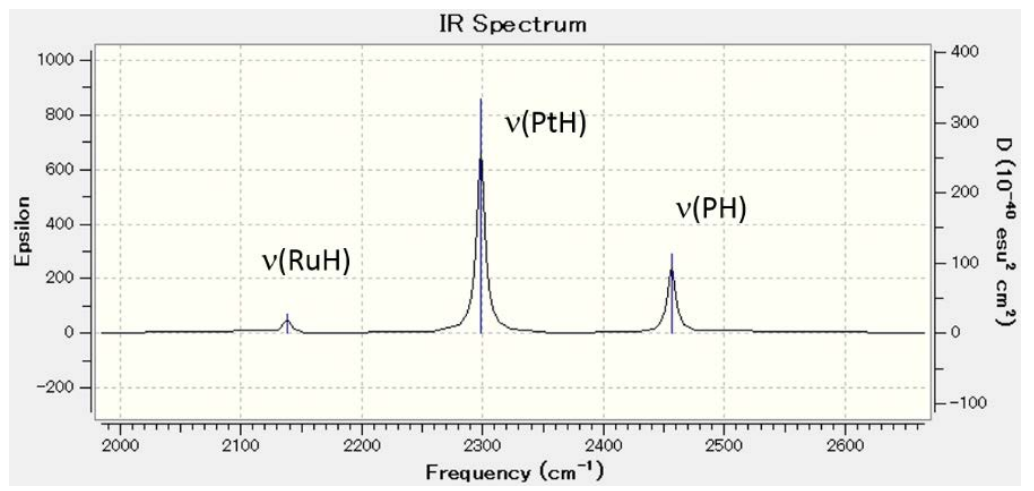

Figure S-14. (a) IR spectrum of $4\left(\mathrm{KBr}, \mathrm{cm}^{-1}\right)$ and (b) Calculated spectrum for the stretching vibrations of $\mathrm{P}-\mathrm{H}, \mathrm{Pt}-\mathrm{H}$, and $\mathrm{Ru}-\mathrm{H}$ bonds in the optimized structure of 4. 
c. The reaction of a mixture of $\mathrm{Cp}{ }^{*} \mathrm{Ru}(\mu-\mathrm{H})_{4} \mathrm{RuCp} *(1)$ and ${ }^{\mathrm{Et}} \mathrm{CpRu}(\mu-\mathrm{H})_{4} \mathrm{Ru}^{\mathrm{Et}} \mathrm{Cp}\left(1^{\prime}\right)$ with $\operatorname{Pt}\left(\mathrm{P}^{\mathrm{t}} \mathrm{Bu} 2 \mathrm{H}\right)_{3}$.

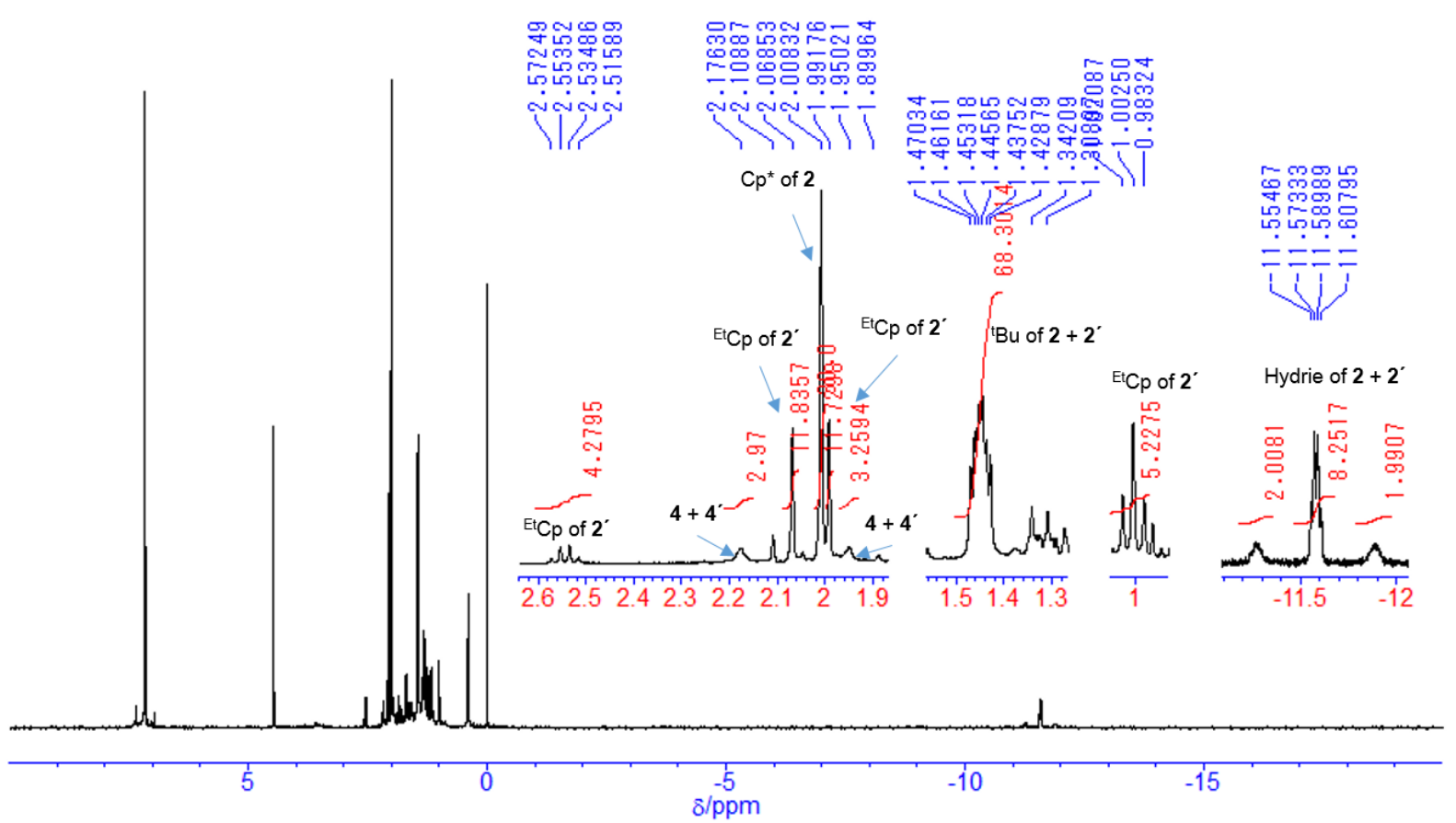

Figure S-15. ${ }^{1} \mathrm{H}$ NMR spectrum of the crude mixture obtained from the reaction of the mixture of $\mathbf{1}$ and $\mathbf{1}^{\prime}$ with $\mathrm{Pt}\left(\mathrm{PBu}_{2} \mathrm{H}_{3}\right)_{3}\left(400 \mathrm{MHz}, \mathrm{C}_{6} \mathrm{D}_{6}, 25{ }^{\circ} \mathrm{C}\right)$. The signal resonating at $\delta 4.46 \mathrm{ppm}$ was derived from $\mathrm{H}_{2}$ introduced in the NMR tube.

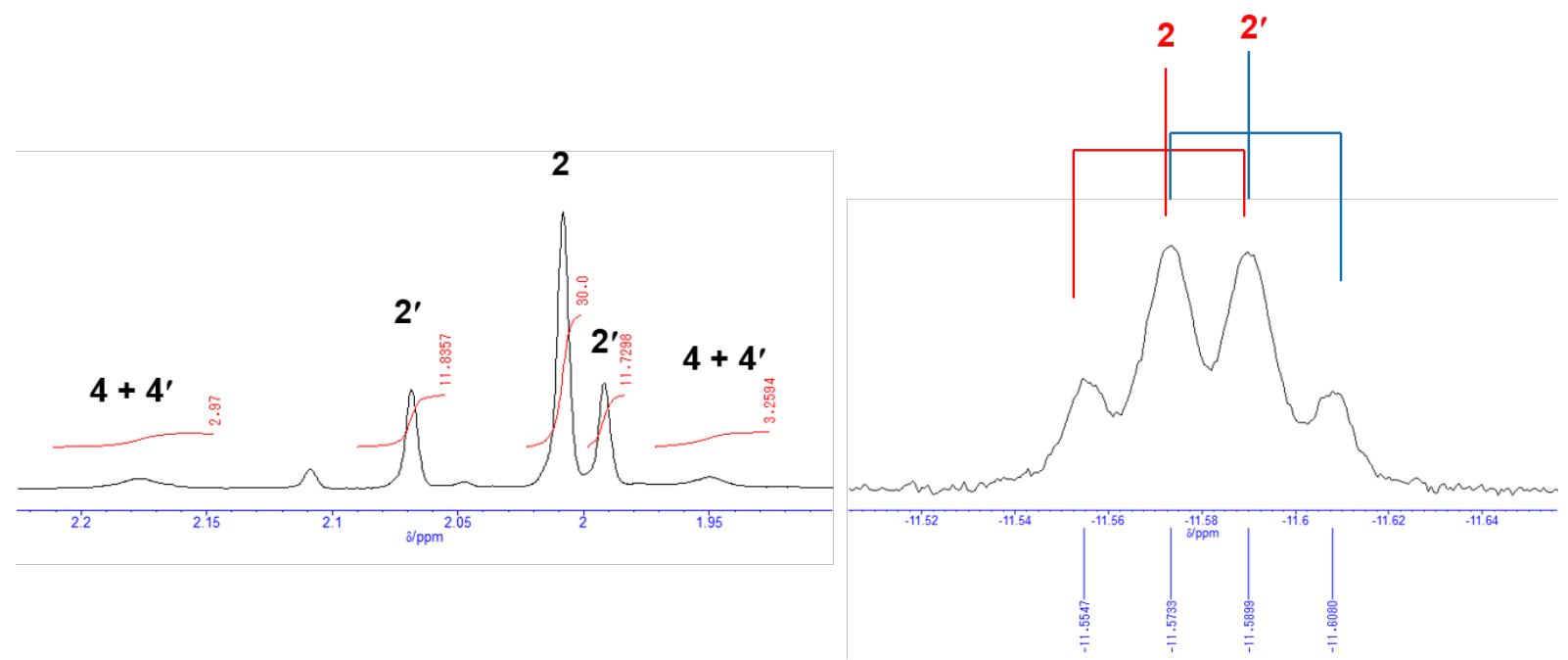

Figure S-16. Enlarged ${ }^{1} \mathrm{H}$ NMR spectra of the crude mixture obtained from the reaction of the mixture of $\mathbf{1}$ and $\mathbf{1}^{\prime}$ with $\mathrm{Pt}\left(\mathrm{PBu}_{2} \mathrm{H}\right)_{3}$ showing $\mathrm{Cp}^{*}$ region (left) and hydrido region (right) $\left(400 \mathrm{MHz}, \mathrm{C}_{6} \mathrm{D}_{6}, 25^{\circ} \mathrm{C}\right)$. 


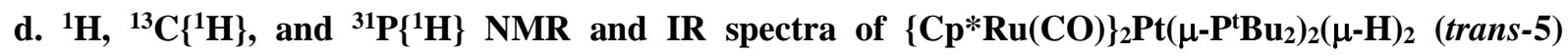

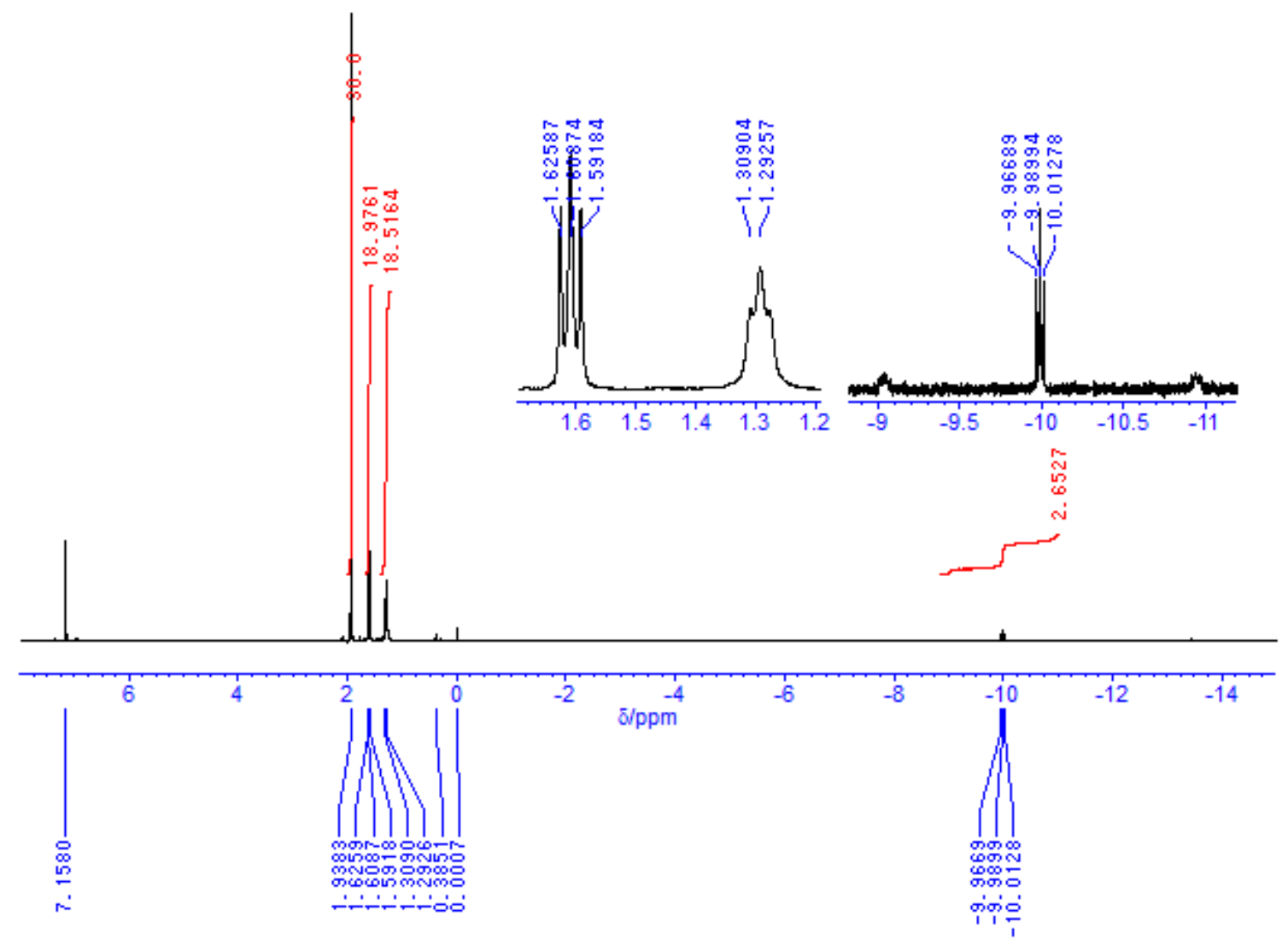

Figure S-17. ${ }^{1} \mathrm{H}$ NMR spectrum of trans-5 (400 MHz, $\left.\mathrm{C}_{6} \mathrm{D}_{6}, 25^{\circ} \mathrm{C}\right)$.

Table S-2. Obtained Parameters for the Curve-Fitting of the $t$-Bu Signal of trans-5

\begin{tabular}{|l|c|c|c|c|c|}
\hline & \multirow{2}{*}{$\begin{array}{c}\text { Nucleus } \\
\text { (number) }\end{array}$} & \multirow{2}{*}{$\delta / \mathrm{ppm}$} & \multirow{2}{*}{$\mathrm{W}(\mathrm{Hz})$} & \multicolumn{2}{|c|}{$J(\mathrm{~Hz})$} \\
\cline { 5 - 6 } & & & 1 & 2 \\
\hline 1 & ${ }^{1} \mathrm{H}(9)$ & 1.609 & 2.0 & --- & ---- \\
\hline 2 & ${ }^{31} \mathrm{P}(1)$ & 201.5 & 1.0 & 12.50 & ---- \\
\hline 3 & ${ }^{31} \mathrm{P}(1)$ & 201.5 & 1.0 & 1.00 & 95.00 \\
\hline
\end{tabular}

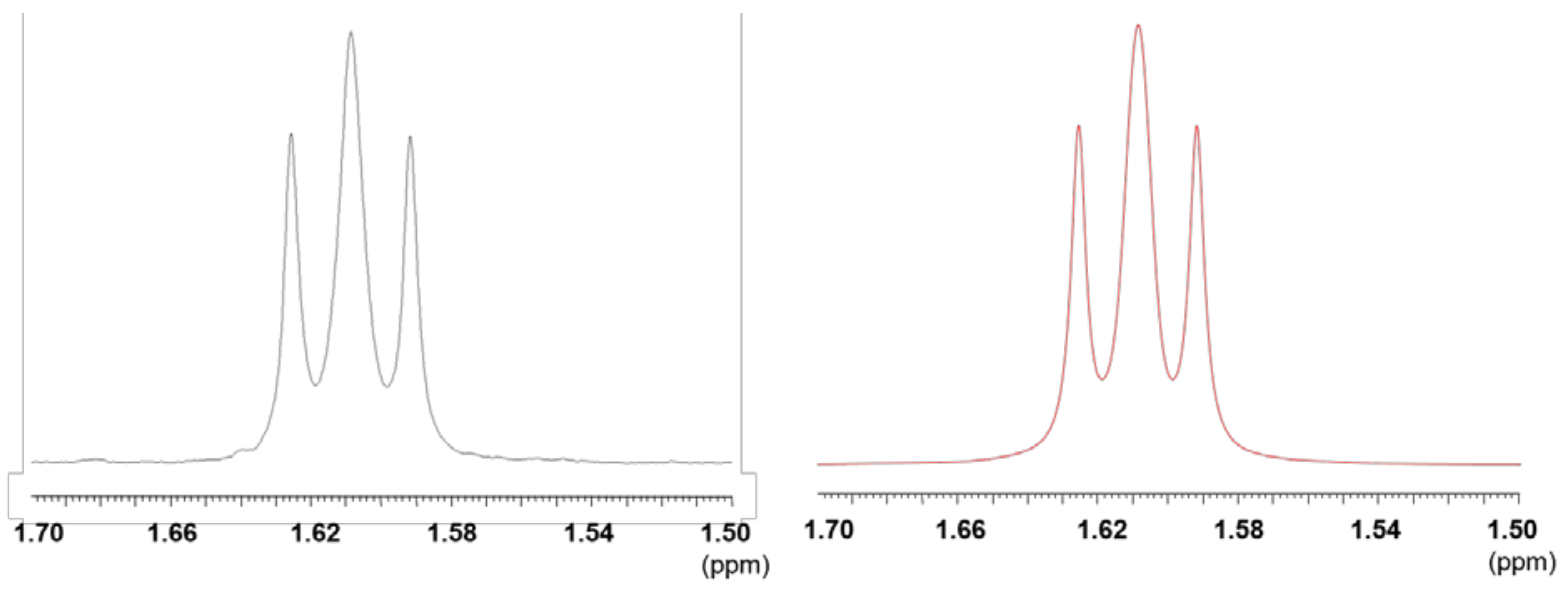

Figure S-18. The $t$-Bu signal of trans- 5 recorded at $25^{\circ} \mathrm{C}\left(400 \mathrm{MHz}, \mathrm{C}_{6} \mathrm{D}_{6}\right.$; left $)$ and the simulated signal obtained from the parameters listed in Table S-2 (right). 


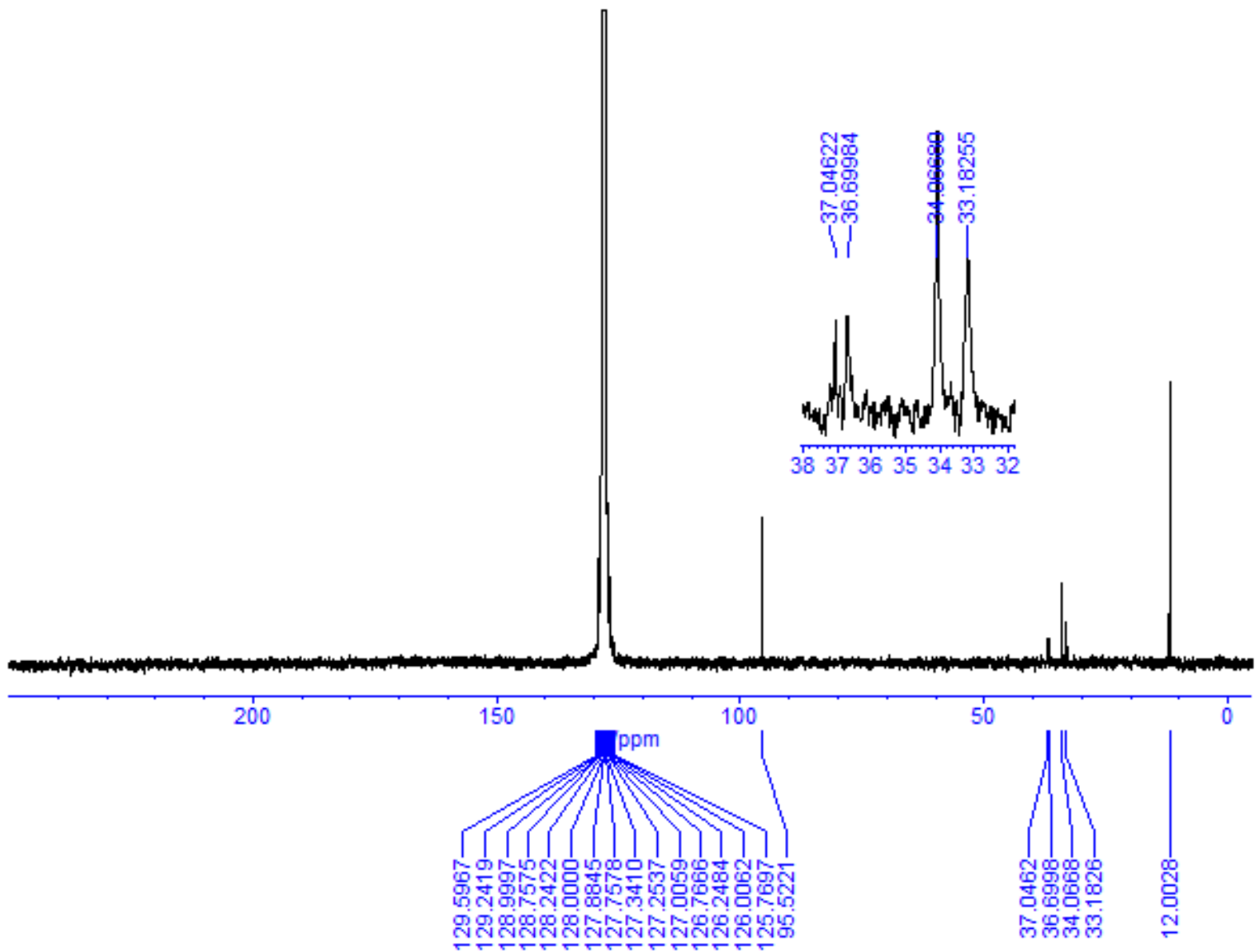

Figure S-19. ${ }^{13} \mathrm{C}\left\{{ }^{1} \mathrm{H}\right\}$ NMR spectrum of trans-5 (400 MHz, $\left.\mathrm{C}_{6} \mathrm{D}_{6}, 25{ }^{\circ} \mathrm{C}\right)$. The signals for one of the quaternary carbons of the $t$-Bu group and $\mathrm{CO}$ groups were not detected because of the broadening of the signals due to equilibrium between trans-5 and cis-5.

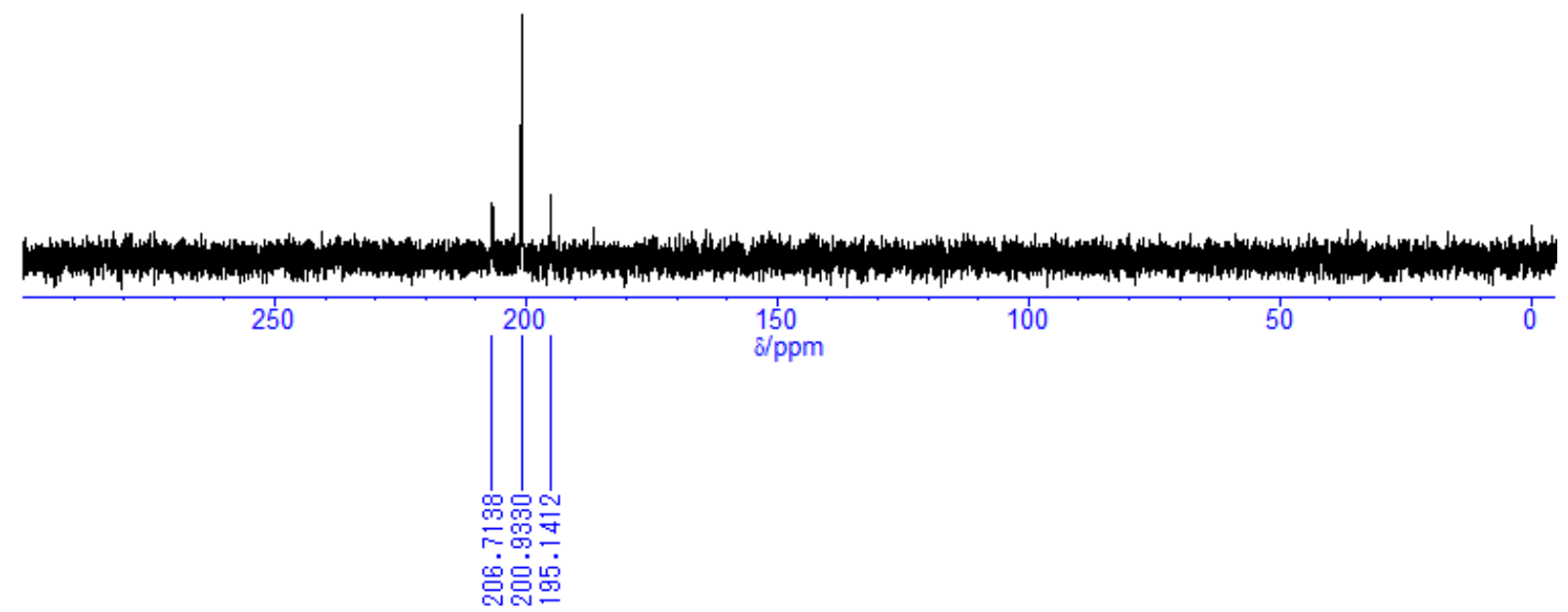

Figure S-20. ${ }^{31} \mathrm{P}\left\{{ }^{1} \mathrm{H}\right\}$ NMR spectrum of trans-5 $\left(162 \mathrm{MHz}, \mathrm{C}_{6} \mathrm{D}_{6}, 25{ }^{\circ} \mathrm{C}\right)$. 


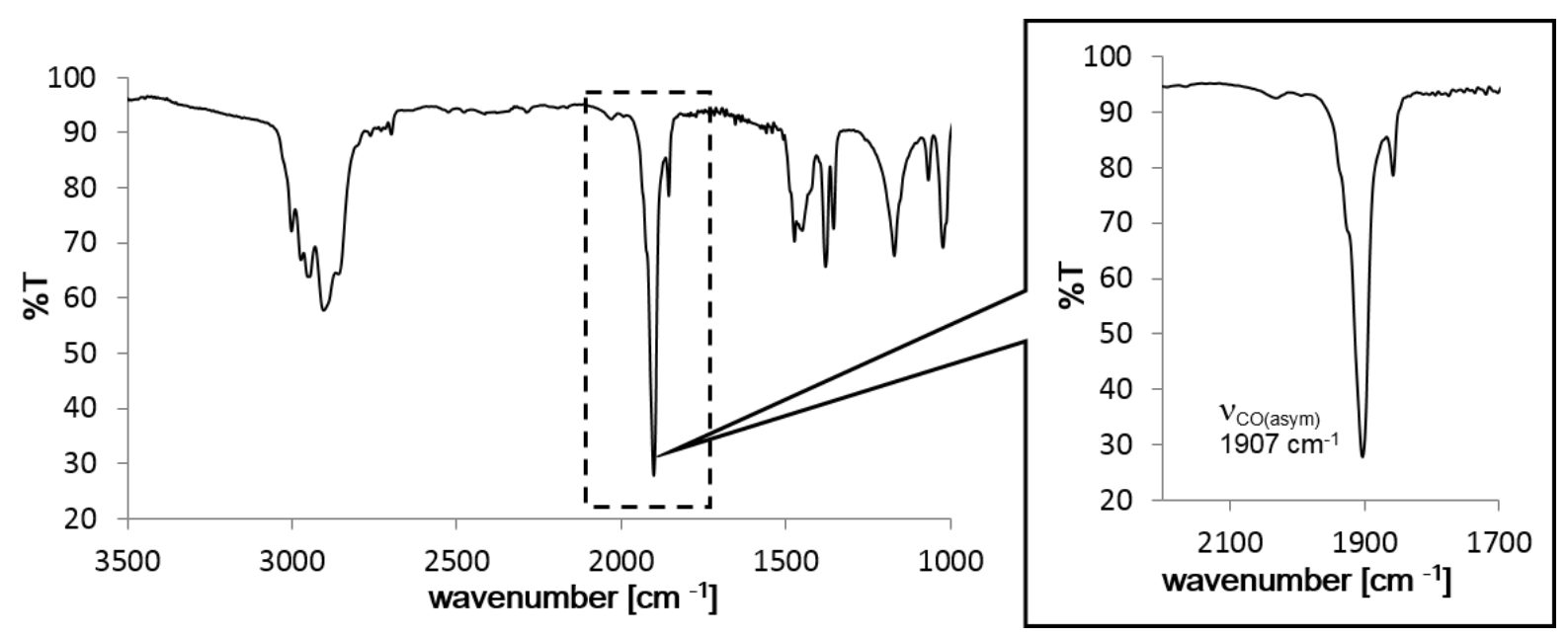

Figure S-21. IR spectrum of trans-5 $\left(\mathrm{KBr}, \mathrm{cm}^{-1}\right)$.

e. ${ }^{1} \mathrm{H}$ and ${ }^{31} \mathrm{P}\left\{{ }^{1} \mathrm{H}\right\}$ NMR and IR spectra of the mixture of cis- and trans-5.

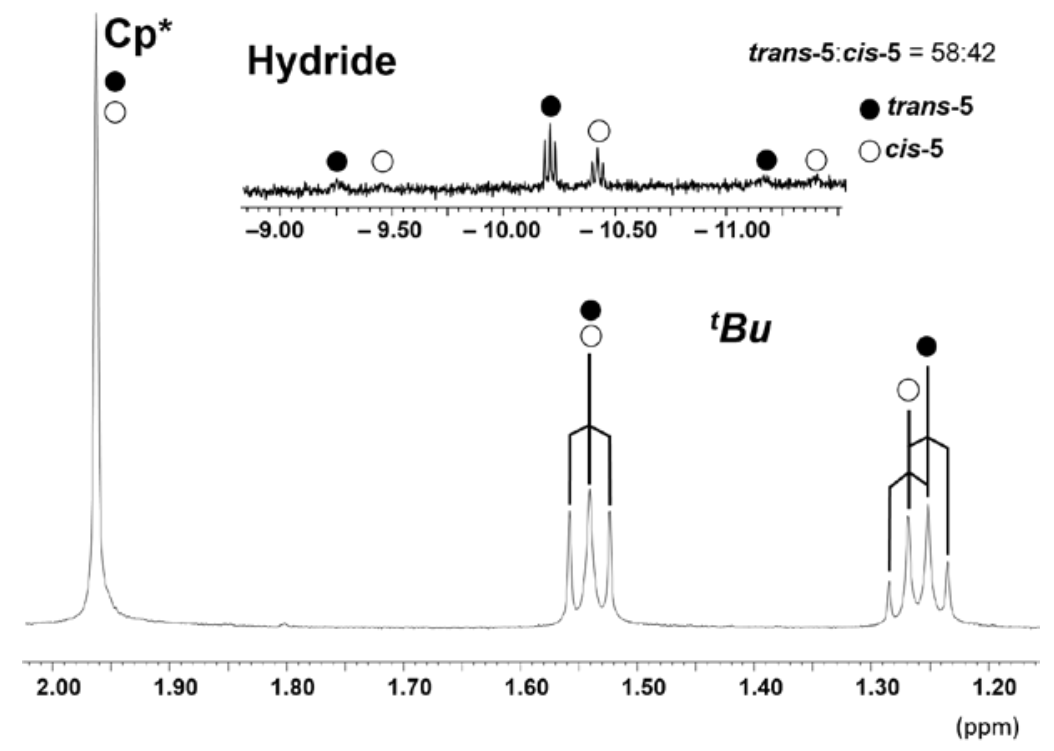

Figure S-22. ${ }^{1} \mathrm{H}$ NMR spectrum of the mixture of cis- and trans-5 in a ratio of $42: 58\left(400 \mathrm{MHz}, \mathrm{C}_{6} \mathrm{D}_{6}, 70{ }^{\circ} \mathrm{C}\right)$. 


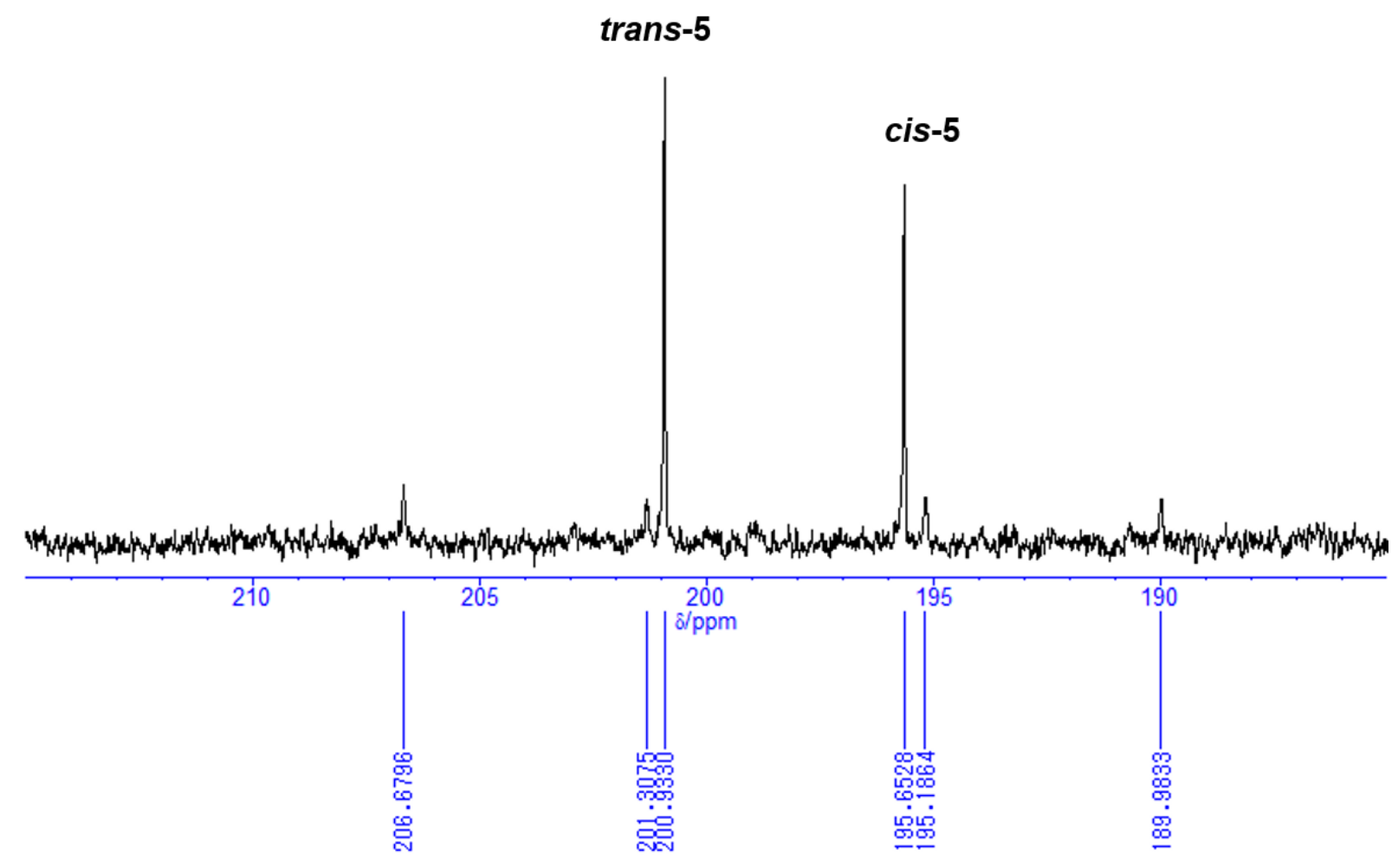

Figure S-23. ${ }^{31} \mathrm{P}\left\{{ }^{1} \mathrm{H}\right\}$ NMR spectrum of the mixture of cis- and trans-5 in a ratio of 42:58 $\left(162 \mathrm{MHz}, \mathrm{C}_{6} \mathrm{D}_{6}\right.$, $\left.25^{\circ} \mathrm{C}\right)$.

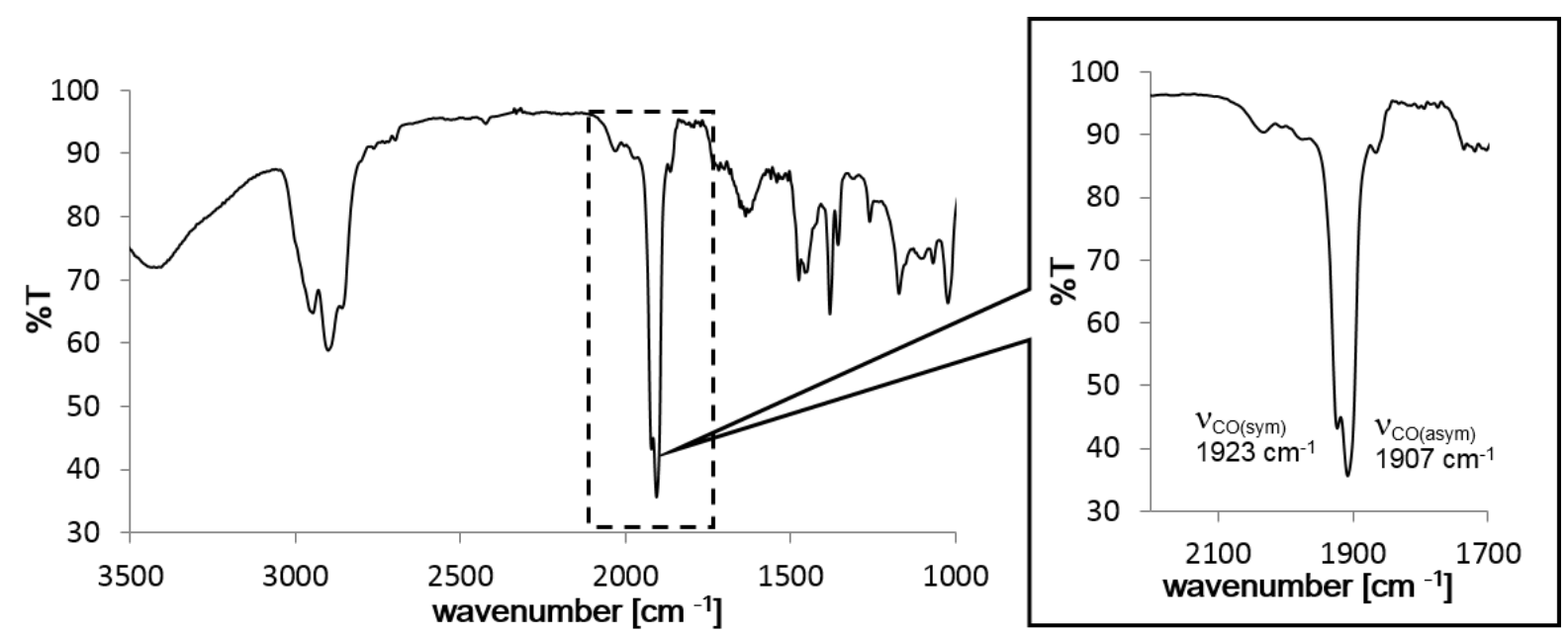

Figure S-24. IR spectrum of the mixture of cis- and trans-5 in a ratio of $42: 58\left(\mathrm{KBr}, \mathrm{cm}^{-1}\right)$. 


\section{f. ${ }^{1} \mathrm{H}$ and ${ }^{31} \mathrm{P}\left\{{ }^{1} \mathrm{H}\right\}$ NMR and IR spectra of $\left\{\mathrm{Cp} * \mathrm{Ru}\left(\mathrm{C}_{2} \mathrm{H}_{4}\right)\right\}_{2} \mathrm{Pt}\left(\mu-\mathrm{P}^{t} \mathrm{Bu}_{2}\right)_{2}(\mu-\mathrm{H})_{2}$ (cis- and trans-6)}

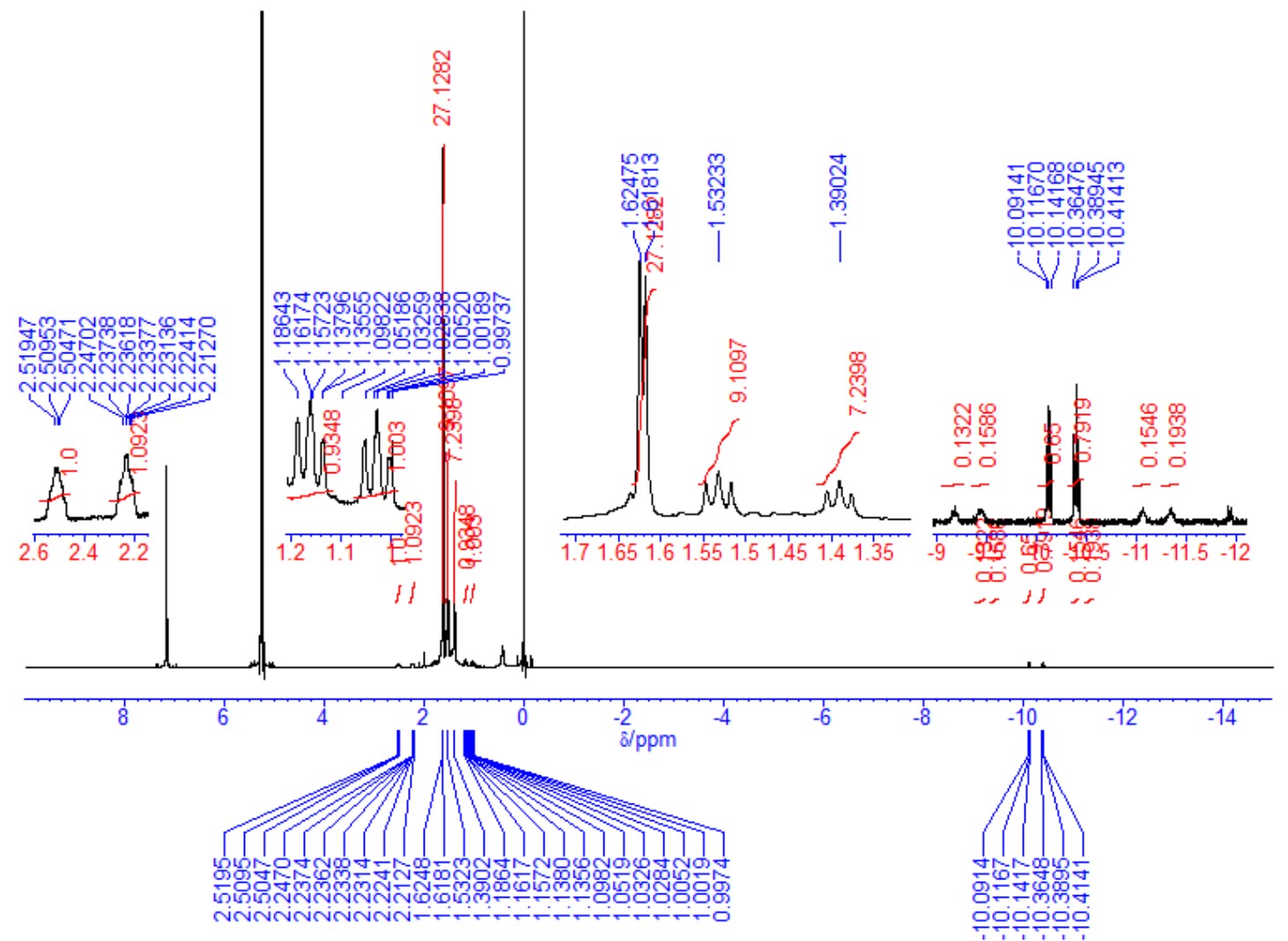

Figure S-25. ${ }^{1} \mathrm{H}$ NMR spectrum of the mixture of cis- and trans-6 $\left(400 \mathrm{MHz}, \mathrm{C}_{6} \mathrm{D}_{6}, 25{ }^{\circ} \mathrm{C}\right)$. The singlet at $\delta 5.25$ ppm was derived from dissolved $\mathrm{C}_{2} \mathrm{H}_{4}$.
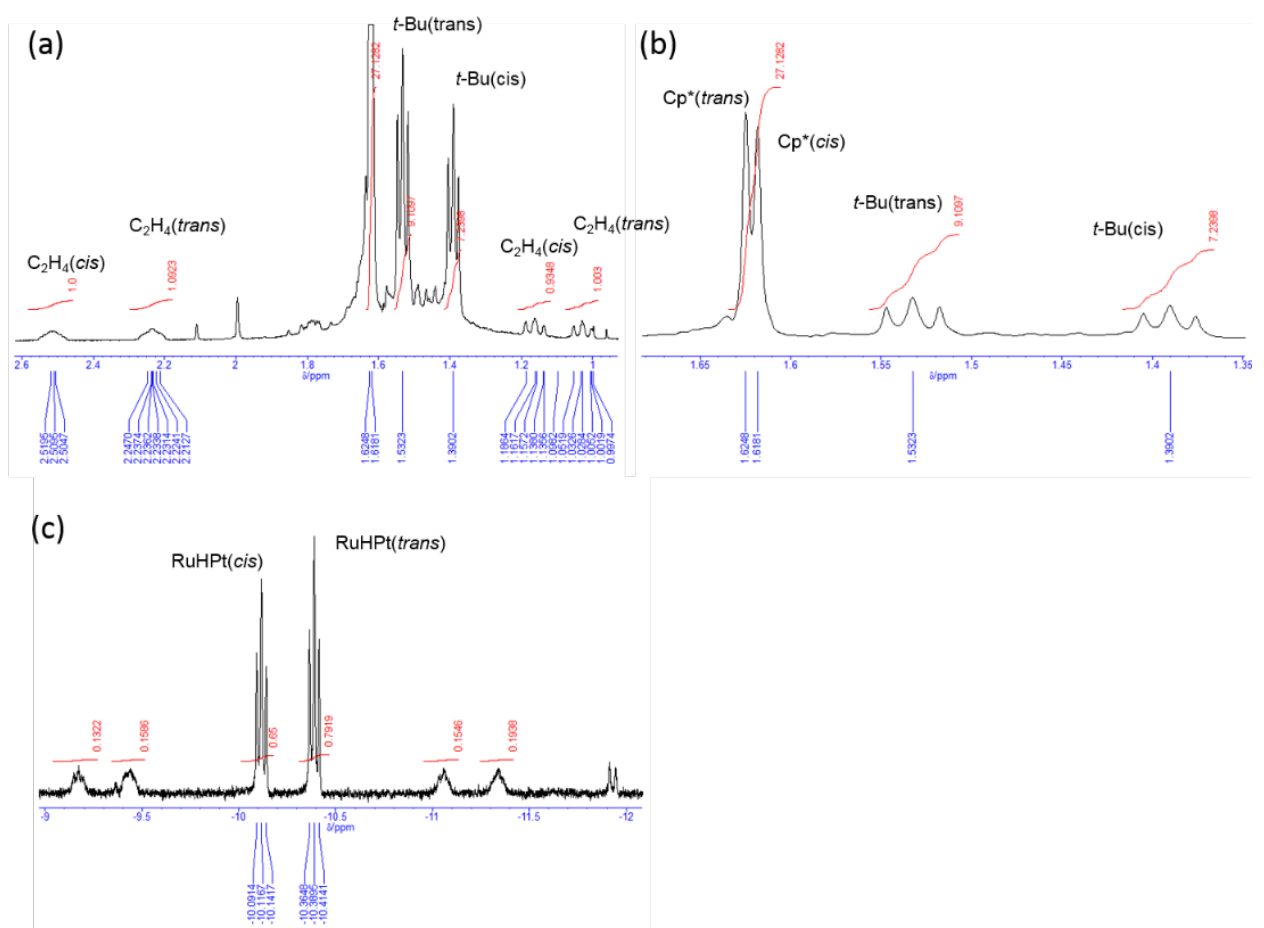

Figure S-26. Enlarged ${ }^{1} \mathrm{H}$ NMR spectra of the mixture of cis- and trans-6 showing (a) $\mathrm{C}_{2} \mathrm{H}_{4}$ and $t \mathrm{Bu}$ region, (b) $\mathrm{Cp}^{*}$ region, and (c) hydrido region $\left(400 \mathrm{MHz}, \mathrm{C}_{6} \mathrm{D}_{6}, 25^{\circ} \mathrm{C}\right)$. 


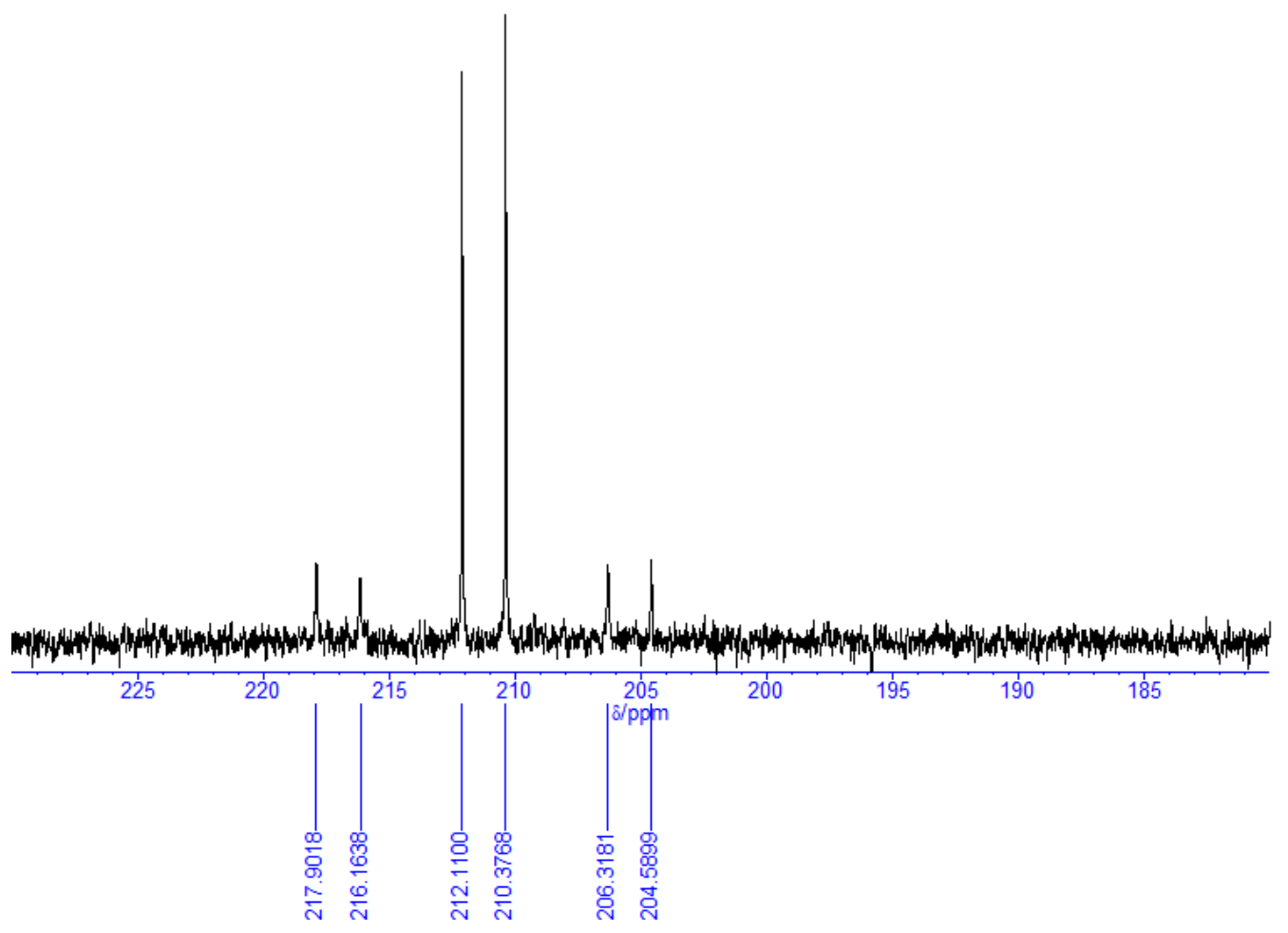

Figure S-27. ${ }^{31} \mathrm{P}\left\{{ }^{1} \mathrm{H}\right\}$ NMR spectrum of the mixture of cis- and trans-6 $\left(162 \mathrm{MHz}, \mathrm{C}_{6} \mathrm{D}_{6}, 2{ }^{\circ} \mathrm{C}\right)$.

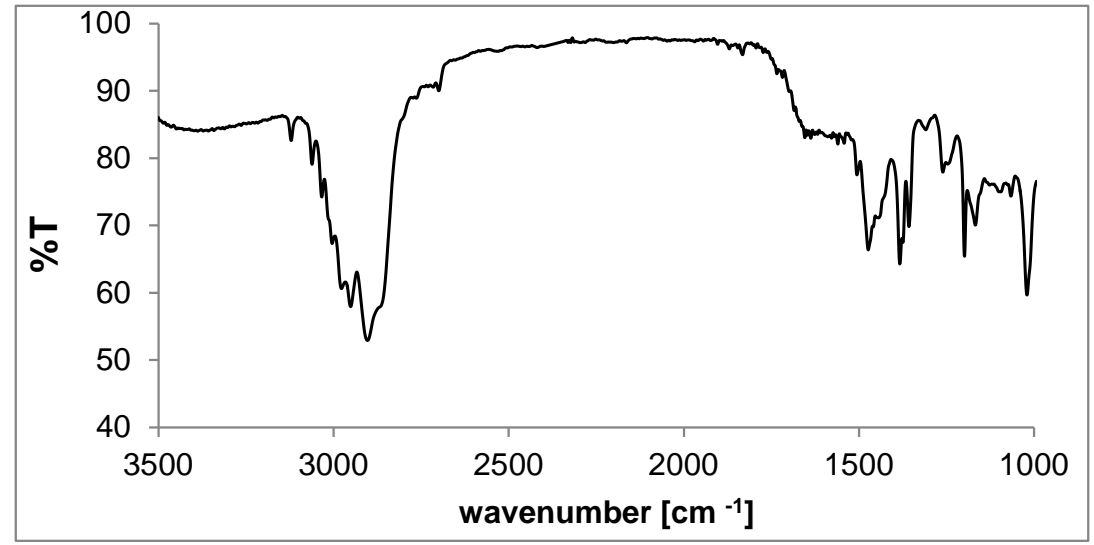

Figure S-28. IR spectrum of the mixture of cis- and trans-6 in a ratio of 45:55 $\left(\mathrm{KBr}, \mathrm{cm}^{-1}\right)$ 
g. ${ }^{1} \mathrm{H}$ NMR spectra of $\left\{\mathrm{Cp} * \mathrm{Ru}(\mathrm{H})_{2}\right\}\left\{\mathrm{Cp} * \mathrm{Ru}\left(\mathrm{C}_{2} \mathrm{H}_{4}\right)\right\} \operatorname{Pt}\left(\mu-\mathrm{P}^{\mathrm{t} B u}\right)_{2}(\mu-\mathrm{H})_{2}(7)$

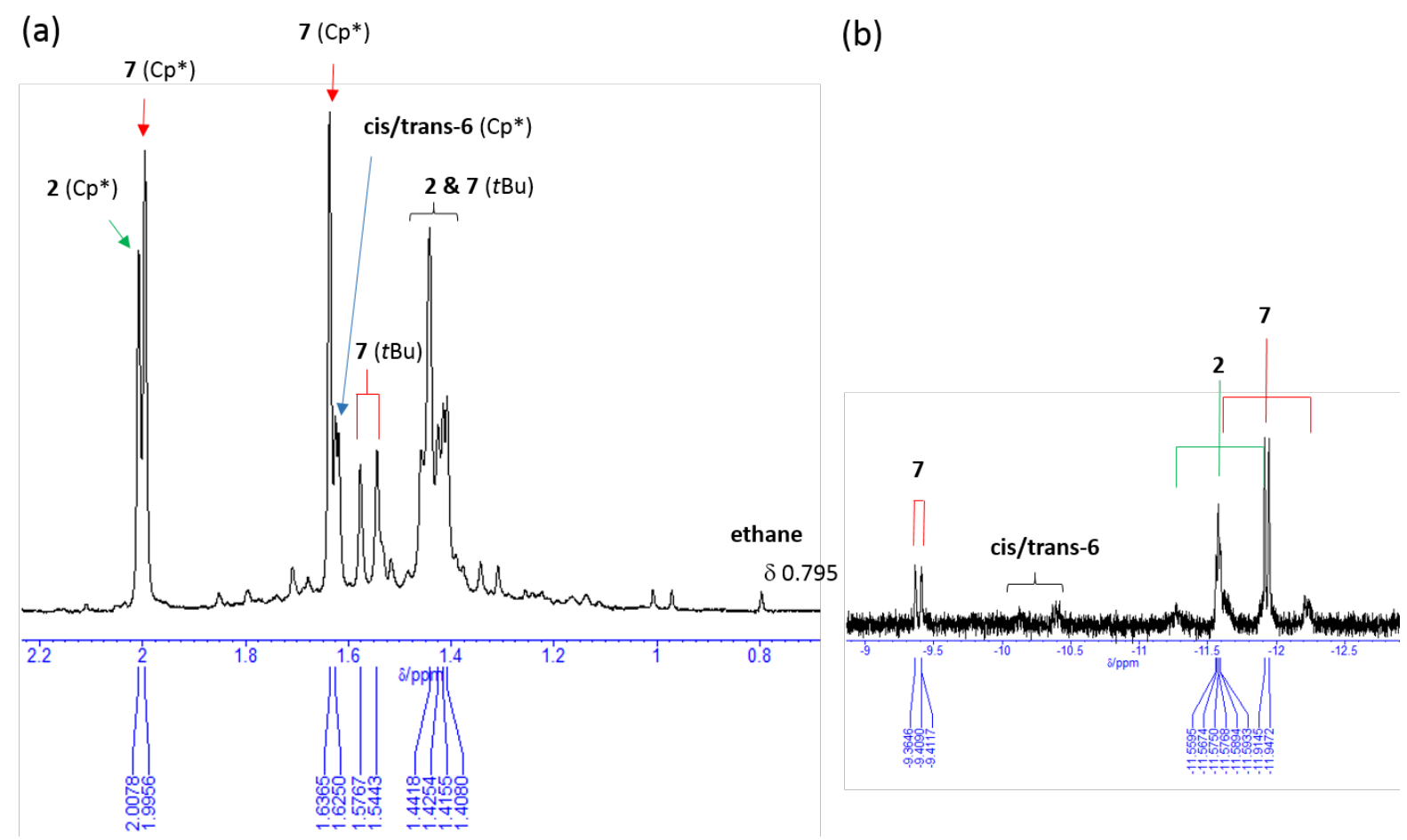

Figure S-29. ${ }^{1} \mathrm{H}$ NMR spectrum of the crude mixture obtained by the reaction of $\mathbf{2}$ with 1 atm of ethylene in 10 min showing (a) Cp* region and (b) hydrido region ( $\left.400 \mathrm{MHz}, \mathrm{C}_{6} \mathrm{D}_{6}, 25^{\circ} \mathrm{C}\right)$. 


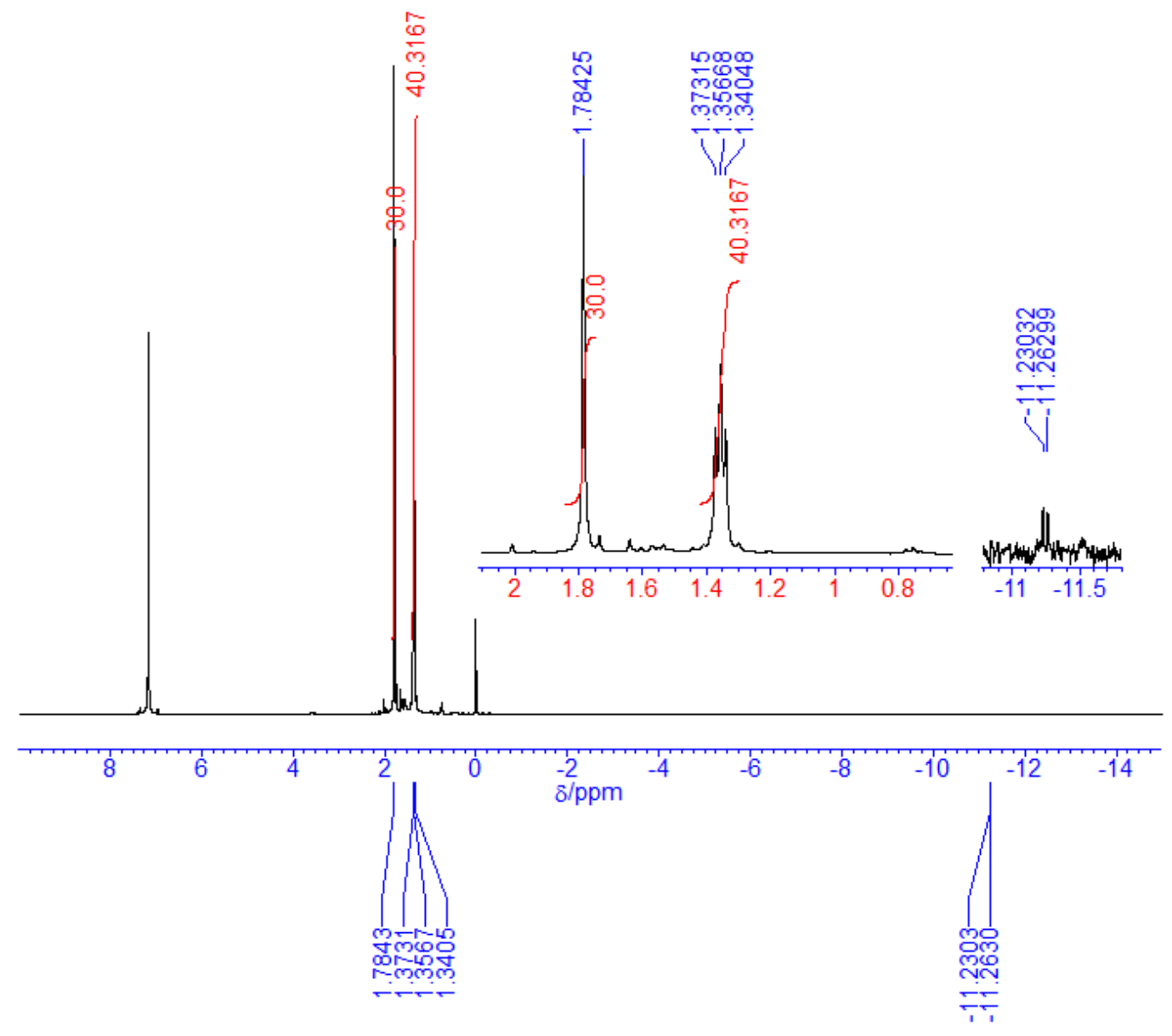

Figure S-30 ${ }^{1} \mathrm{H}$ NMR spectrum of $8\left(400 \mathrm{MHz}, \mathrm{C}_{6} \mathrm{D}_{6}, 25^{\circ} \mathrm{C}\right)$. Due to the low concentration of 8 , the satellite signals could not be observed around the hydrido signals. The $J_{\mathrm{Pt}-\mathrm{H}}$ value was estimated at $207 \mathrm{~Hz}$ from the ${ }^{1} \mathrm{H}$ NMR spectrum recorded using a crude mixture of 8 as shown in Figure S-26.

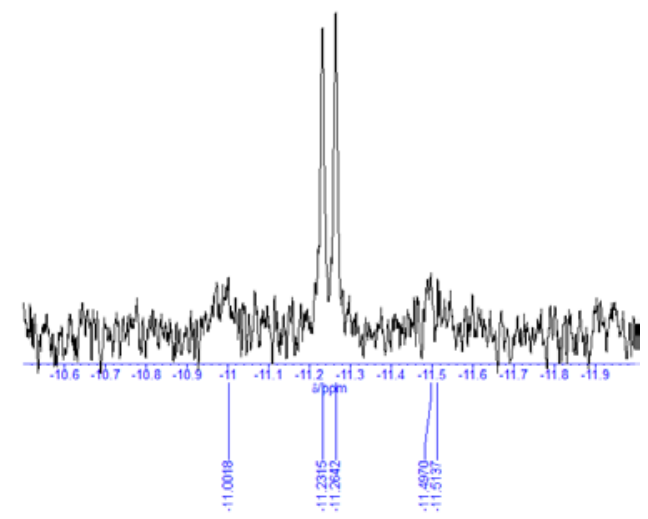

Figure S-31. Hydrido signal of $8\left(400 \mathrm{MHz}, \mathrm{C}_{6} \mathrm{D}_{6}, 25^{\circ} \mathrm{C}\right)$. 
Table S-3. Obtained Parameters for the Curve-Fitting of the $t$-Bu Signal of 8

\begin{tabular}{|c|c|c|c|c|c|}
\hline & \multirow{2}{*}{$\begin{array}{c}\text { Nucleus } \\
\text { (number) }\end{array}$} & \multirow{2}{*}{$\delta / \mathrm{ppm}$} & \multirow{2}{*}{$\mathrm{W}(\mathrm{Hz})$} & \multicolumn{2}{|c|}{$J(\mathrm{~Hz})$} \\
\cline { 5 - 6 } & & & 1 & 2 \\
\hline 1 & ${ }^{1} \mathrm{H}(9)$ & 1.357 & 3.6 & --- & ---- \\
\hline 2 & ${ }^{31} \mathrm{P}(1)$ & 164.6 & 1.0 & 12.50 & ---- \\
\hline 3 & ${ }^{31} \mathrm{P}(1)$ & 164.6 & 1.0 & 1.20 & 90 \\
\hline
\end{tabular}

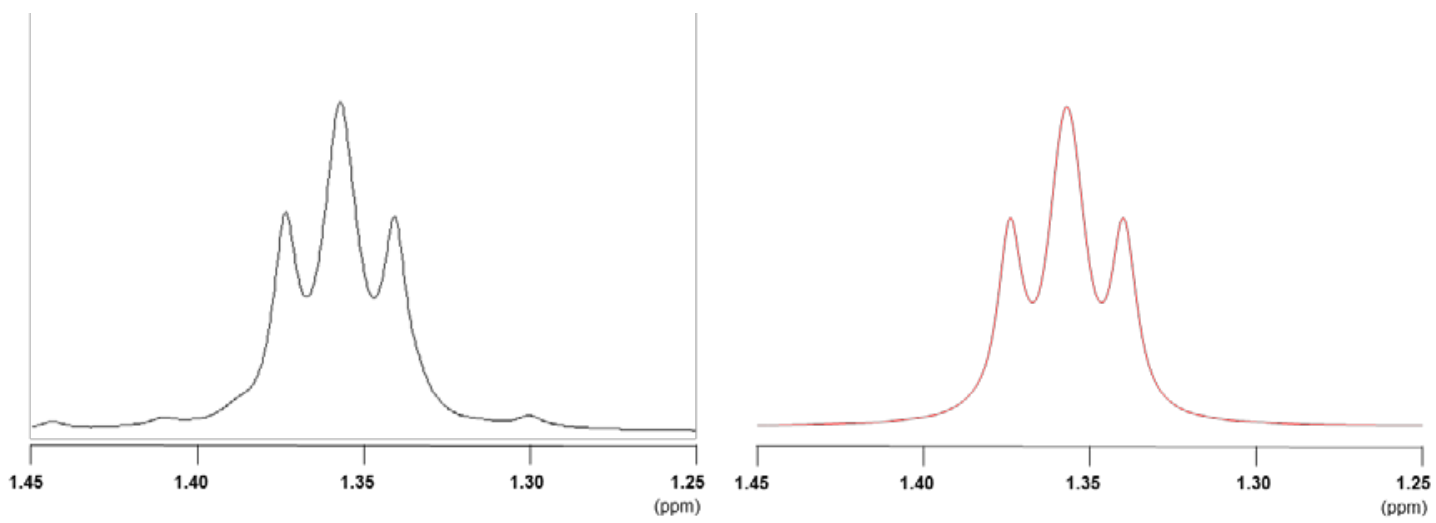

Figure S-32. The $t$-Bu signal of 8 recorded at $25{ }^{\circ} \mathrm{C}\left(400 \mathrm{MHz}, \mathrm{C}_{6} \mathrm{D}_{6}\right.$; left) and the simulated signal obtained from the parameters listed in Table S-3 (right).

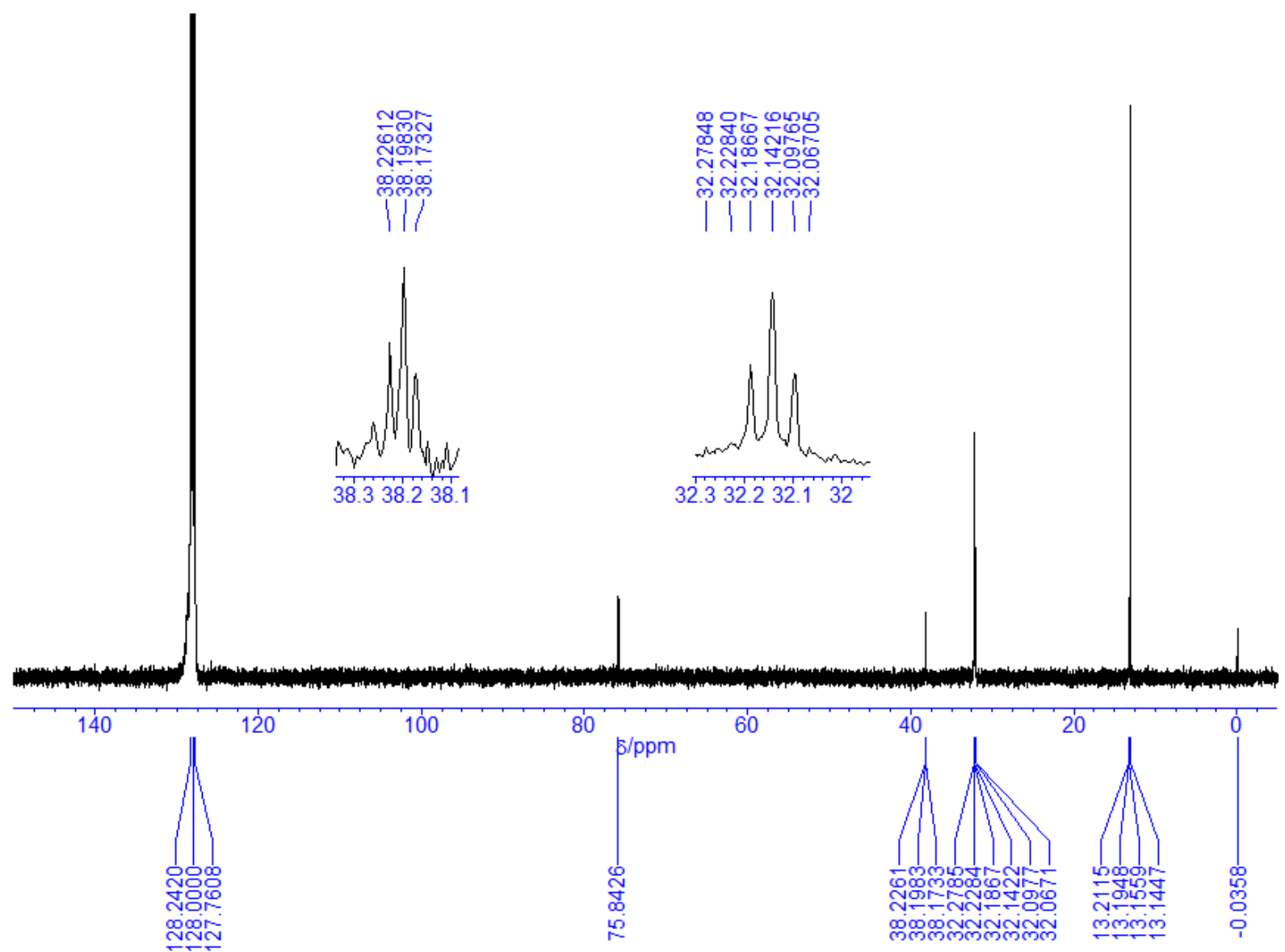

Figure S-33. ${ }^{13} \mathrm{C}\left\{{ }^{1} \mathrm{H}\right\}$ NMR spectrum of $8\left(100 \mathrm{MHz}, \mathrm{C}_{6} \mathrm{D}_{6}, 25{ }^{\circ} \mathrm{C}\right)$. 


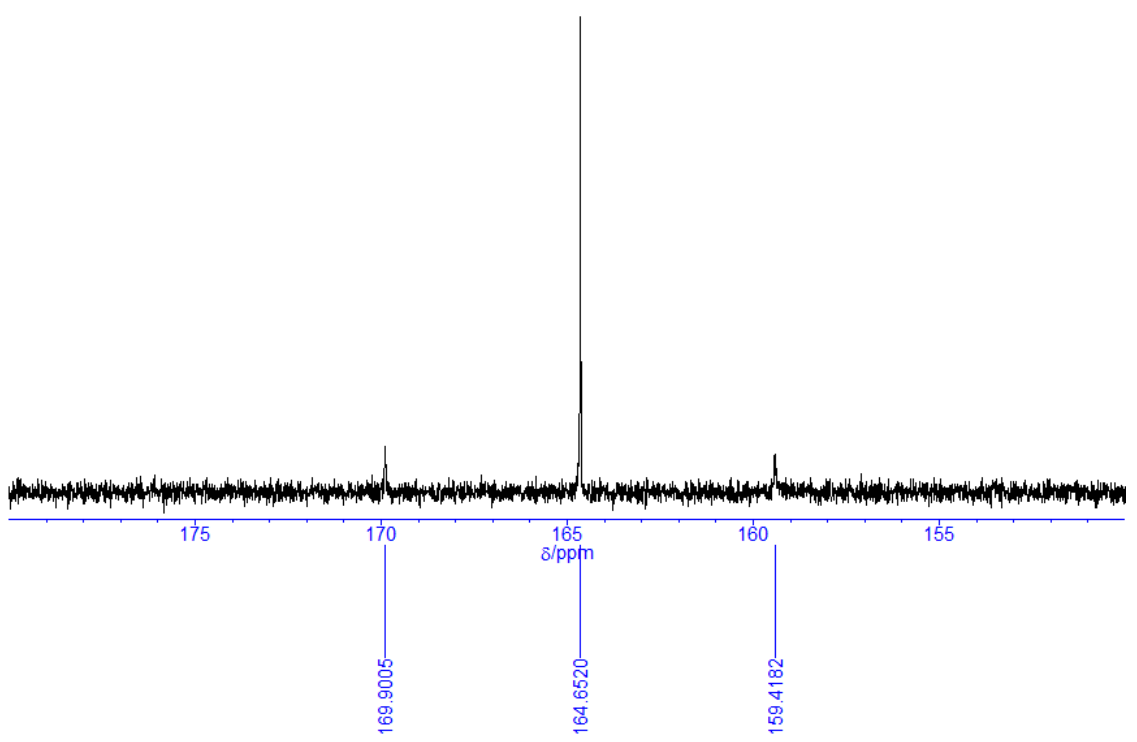

Figure S-34. ${ }^{31} \mathrm{P}\left\{{ }^{1} \mathrm{H}\right\}$ NMR spectrum of $8\left(162 \mathrm{MHz}, \mathrm{C}_{6} \mathrm{D}_{6}, 25^{\circ} \mathrm{C}\right)$.

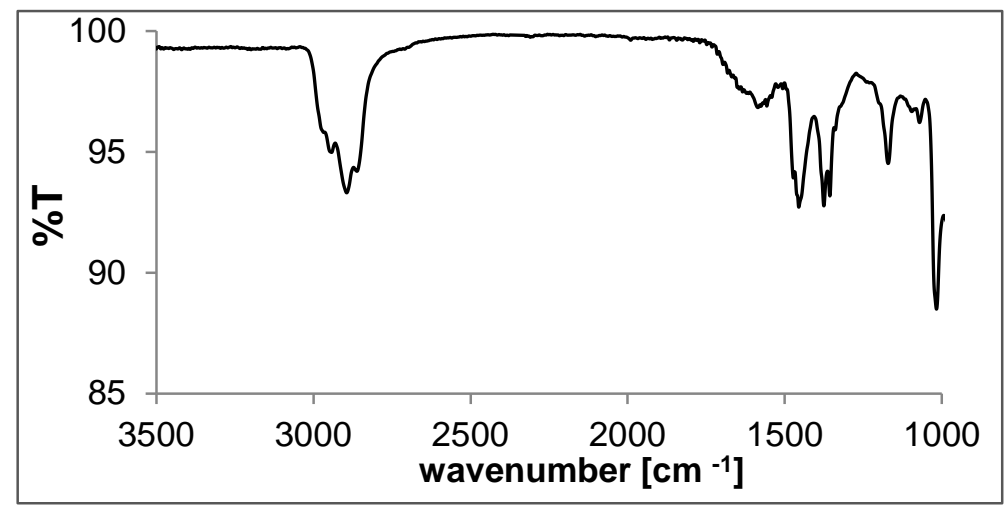

Figure S-35. IR spectrum of 8 (ATR, $\left.\mathrm{cm}^{-1}\right)$ 


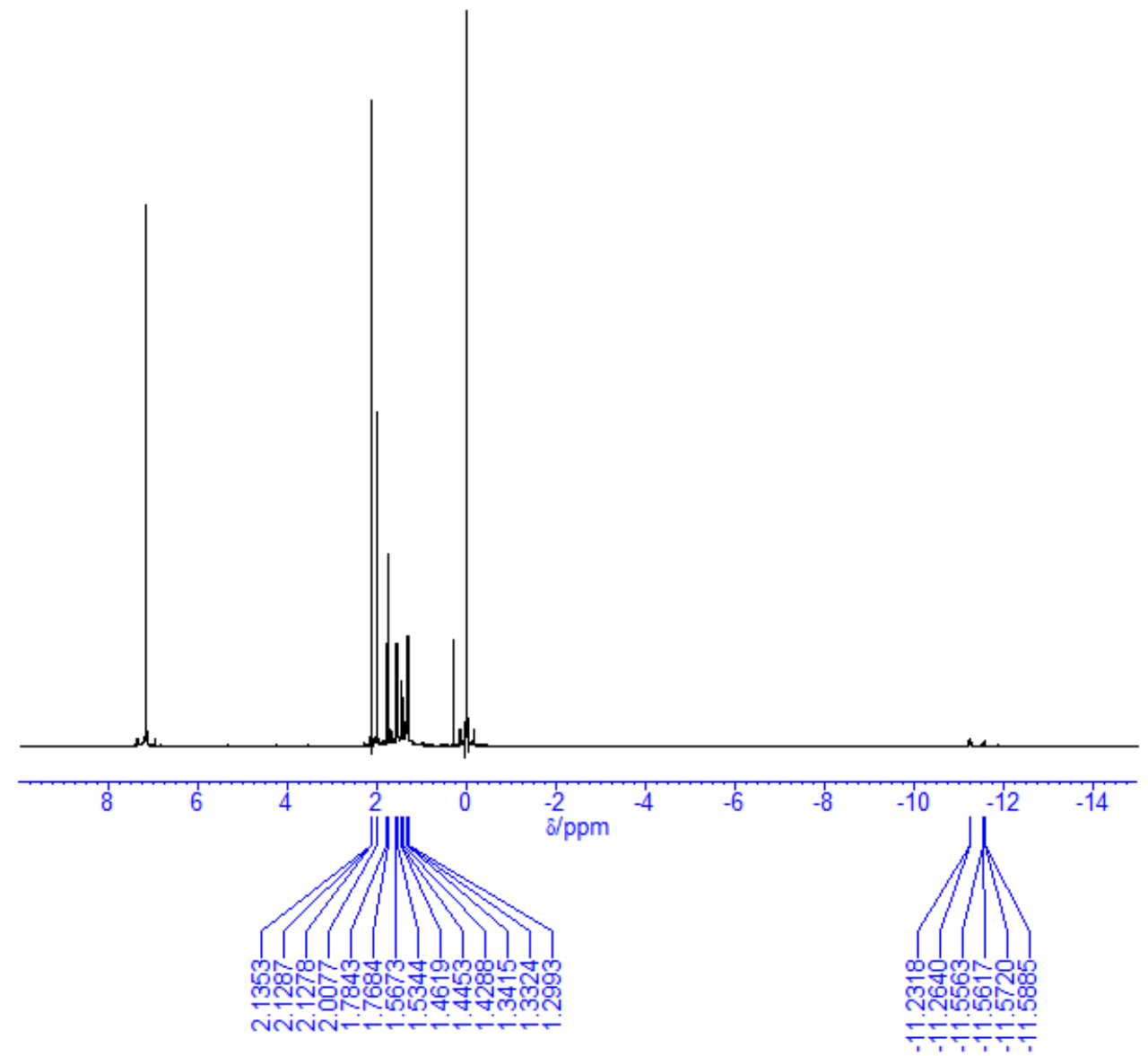

Figure S-36. ${ }^{1} \mathrm{H}$ NMR spectrum of a mixture including 2 , 3, and 8 (400 MHz, $\left.\mathrm{C}_{6} \mathrm{D}_{6}, 25^{\circ} \mathrm{C}\right)$.

(a)

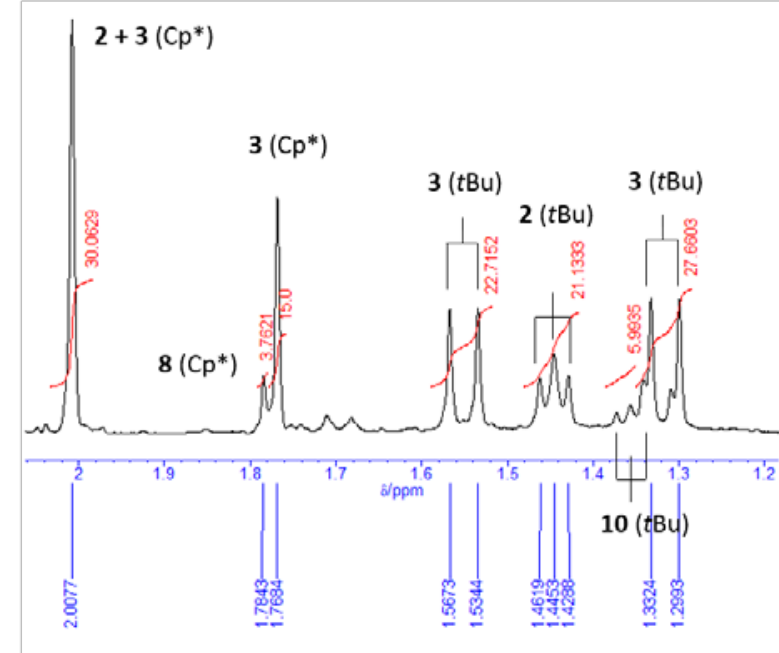

(b)

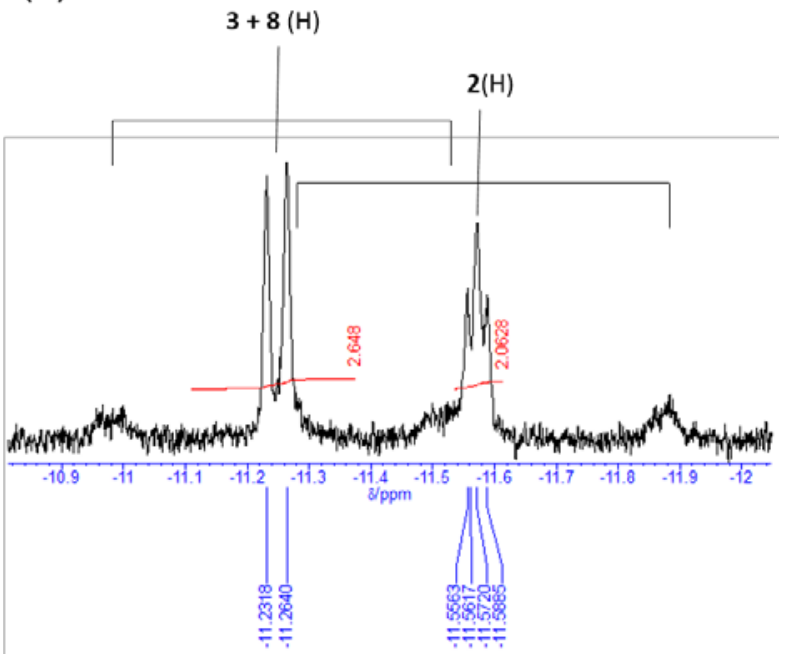

Figure S-37. Enlarged ${ }^{1} \mathrm{H}$ NMR spectrum of a mixture including 2, 3, and 8 showing (a) $\mathrm{Cp}^{*}$ region and (b) hydrido region $\left(400 \mathrm{MHz}, \mathrm{C}_{6} \mathrm{D}_{6}, 25^{\circ} \mathrm{C}\right)$. 
3

3

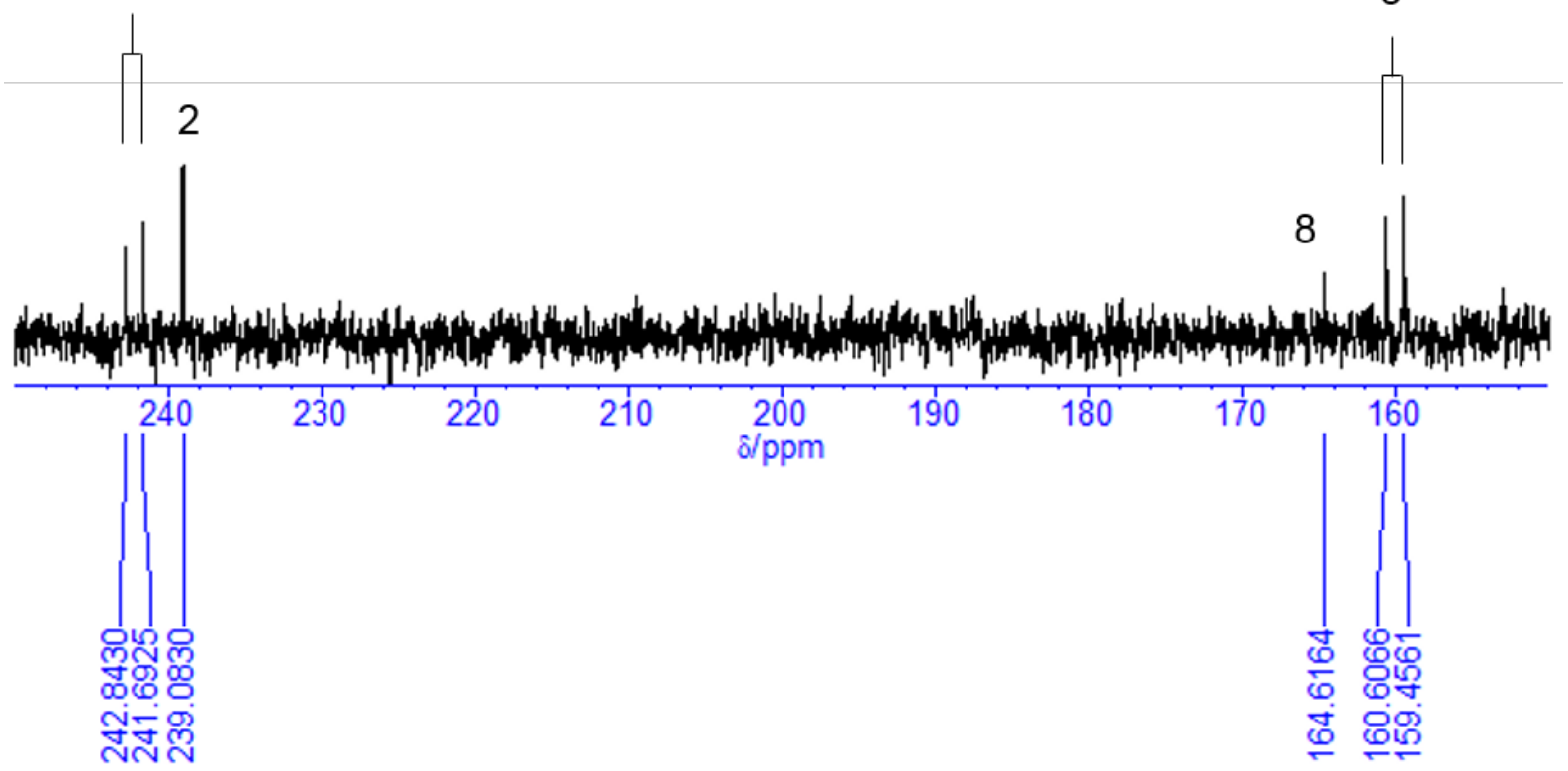

Figure S-38. ${ }^{31} \mathrm{P}\left\{{ }^{1} \mathrm{H}\right\}$ NMR spectrum of a mixture including 2, 3, and $8\left(162 \mathrm{MHz}, \mathrm{C}_{6} \mathrm{D}_{6}, 2{ }^{\circ} \mathrm{C}\right)$. 


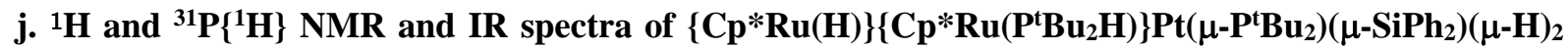
(cis- and trans-9)

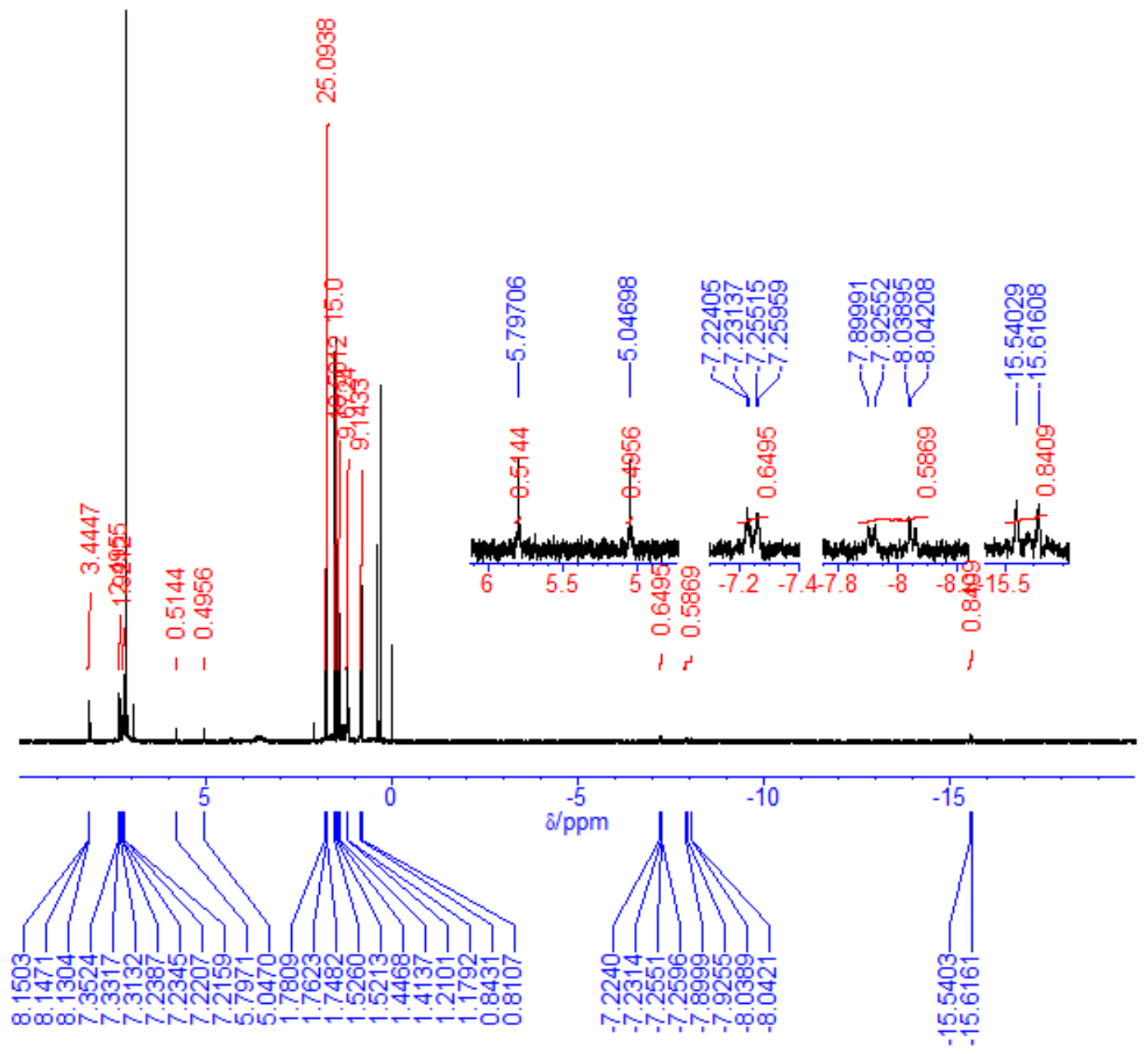

Figure S-39. ${ }^{1} \mathrm{H}$ NMR spectrum of cis-9 $\left(400 \mathrm{MHz}, \mathrm{C}_{6} \mathrm{D}_{6}, 25^{\circ} \mathrm{C}\right)$.

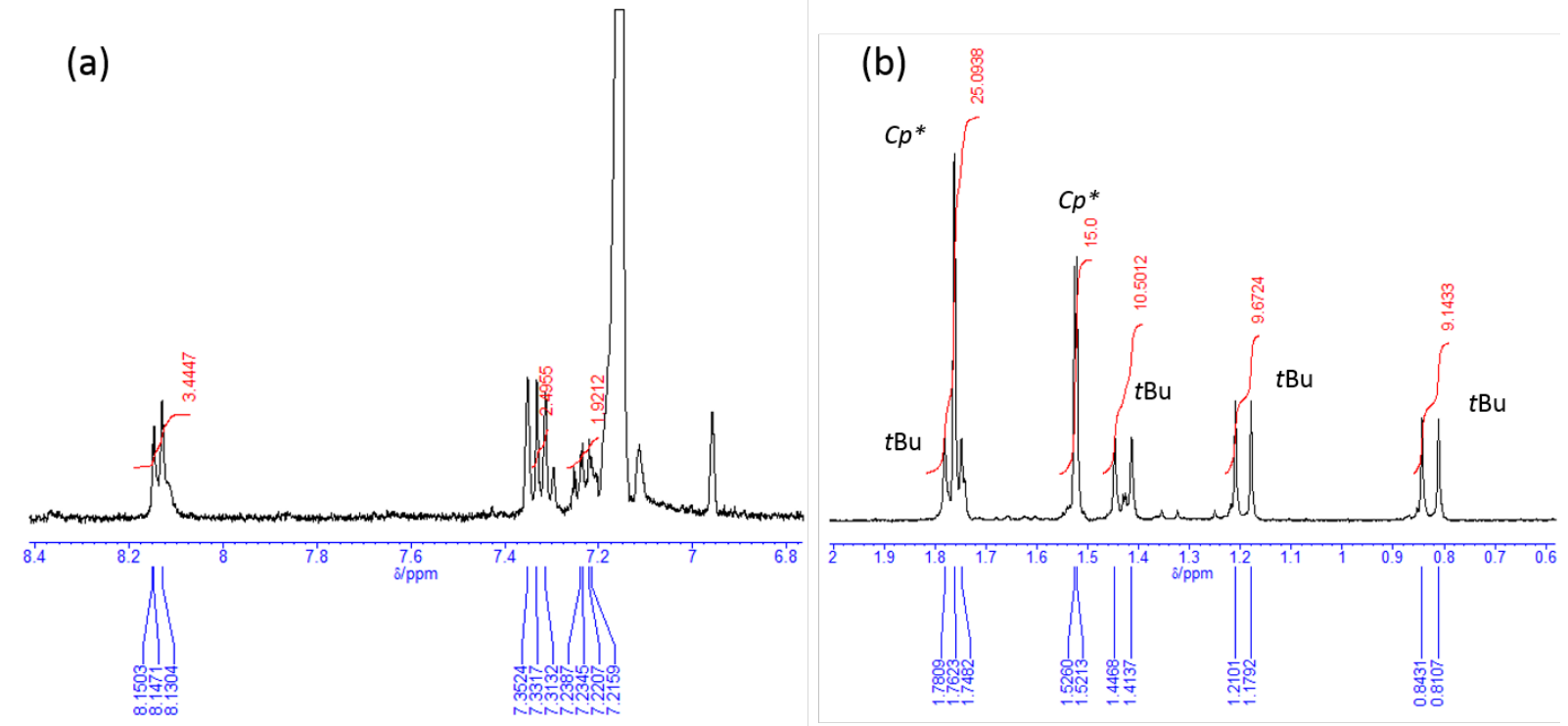

Figure S-40. Enlarged ${ }^{1} \mathrm{H}$ NMR spectra of cis-9 showing (a) Ph region and (b) $\mathrm{Cp}^{*}$ region (400 MHz, $\mathrm{C}_{6} \mathrm{D}_{6}$, $\left.25^{\circ} \mathrm{C}\right)$. 


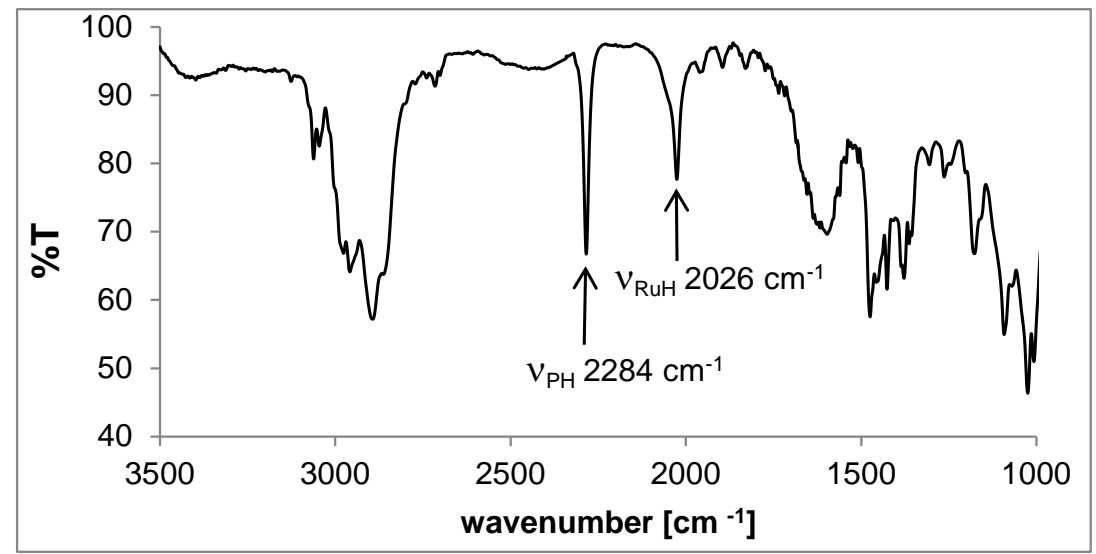

Figure S-41. IR spectrum of cis-9 $\left(\mathrm{KBr}, \mathrm{cm}^{-1}\right)$

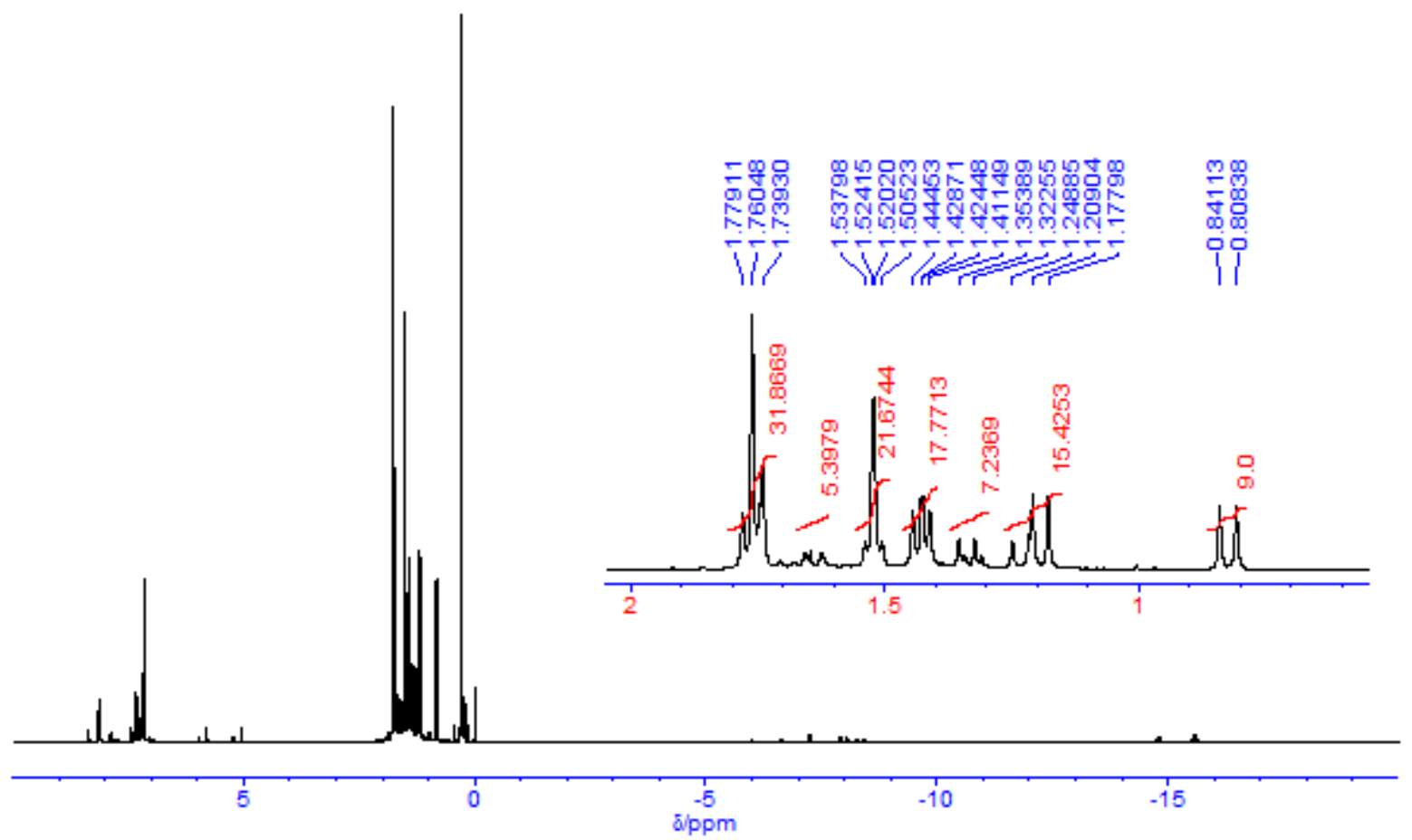

Figure S-42. ${ }^{1} \mathrm{H}$ NMR spectrum of the mixture of cis- and trans-9 (400 MHz, $\mathrm{C}_{6} \mathrm{D}_{6}, 25{ }^{\circ} \mathrm{C}$ ). 


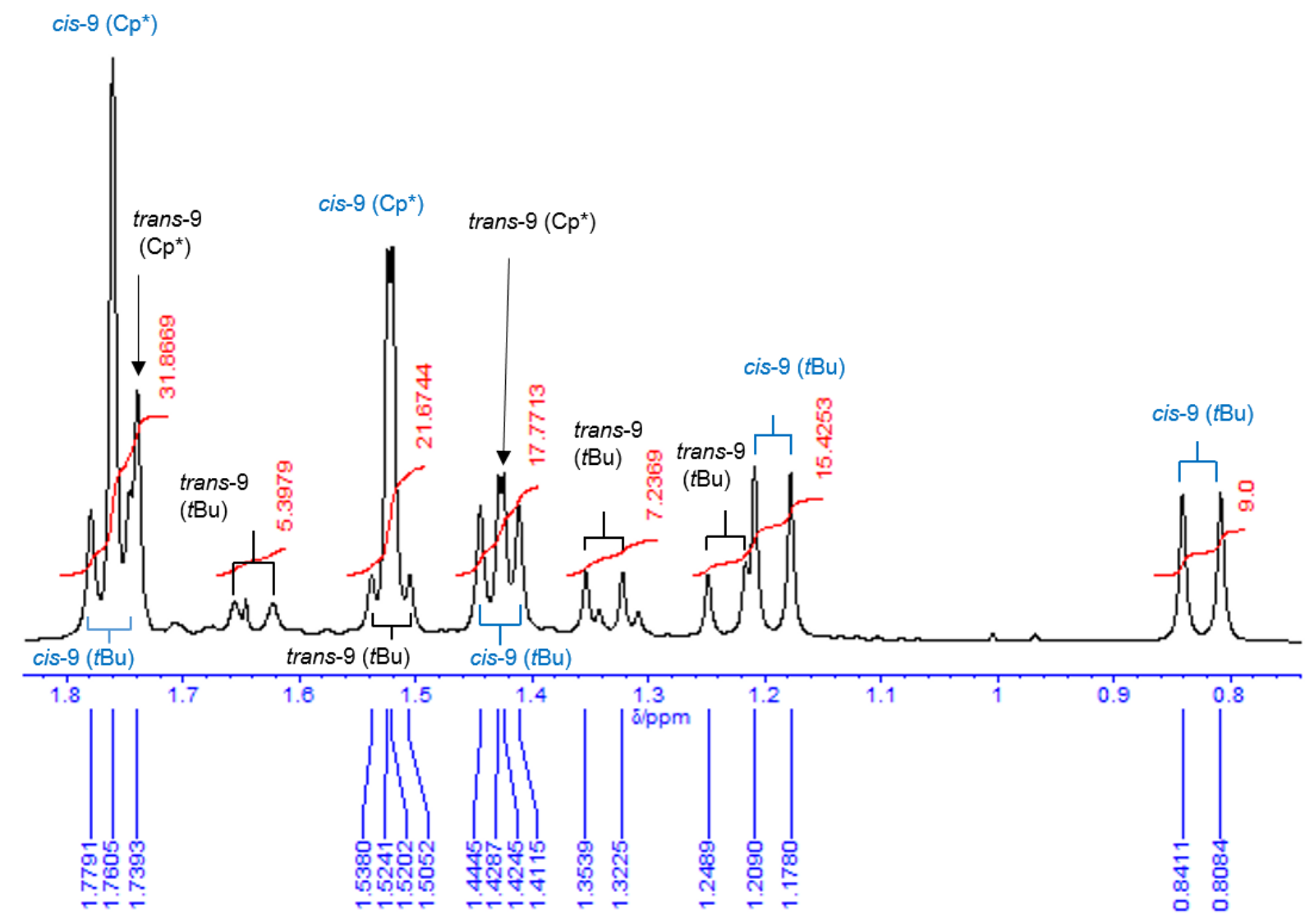

Figure S-43. Enlarged ${ }^{1} \mathrm{H}$ NMR spectrum of the mixture of cis- and trans-9 showing $\mathrm{Cp}^{*}$ and $t$-Bu region (400 MHz, $\mathrm{C}_{6} \mathrm{D}_{6}, 25^{\circ} \mathrm{C}$ ). 

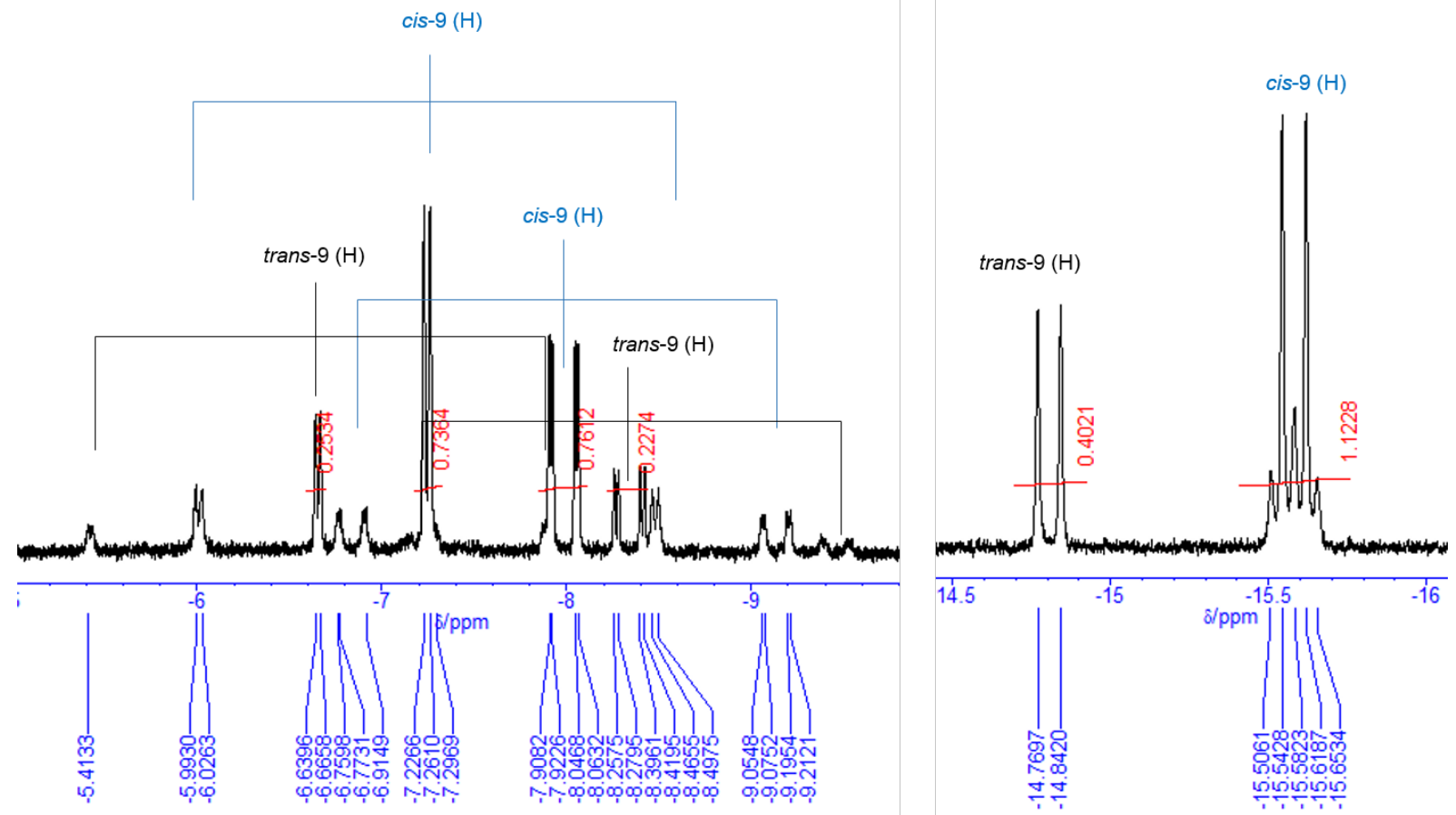

Figure S-44. Enlarged ${ }^{1} \mathrm{H}$ NMR spectrum of the mixture of cis- and trans-9 showing hydrido region (400 $\left.\mathrm{MHz}, \mathrm{C}_{6} \mathrm{D}_{6}, 25^{\circ} \mathrm{C}\right)$.

(a)

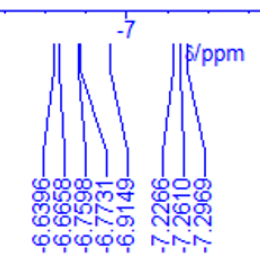

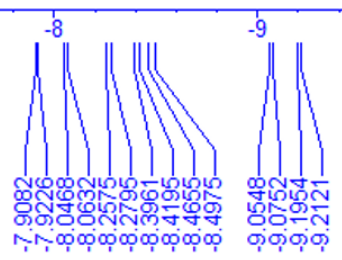

(a)

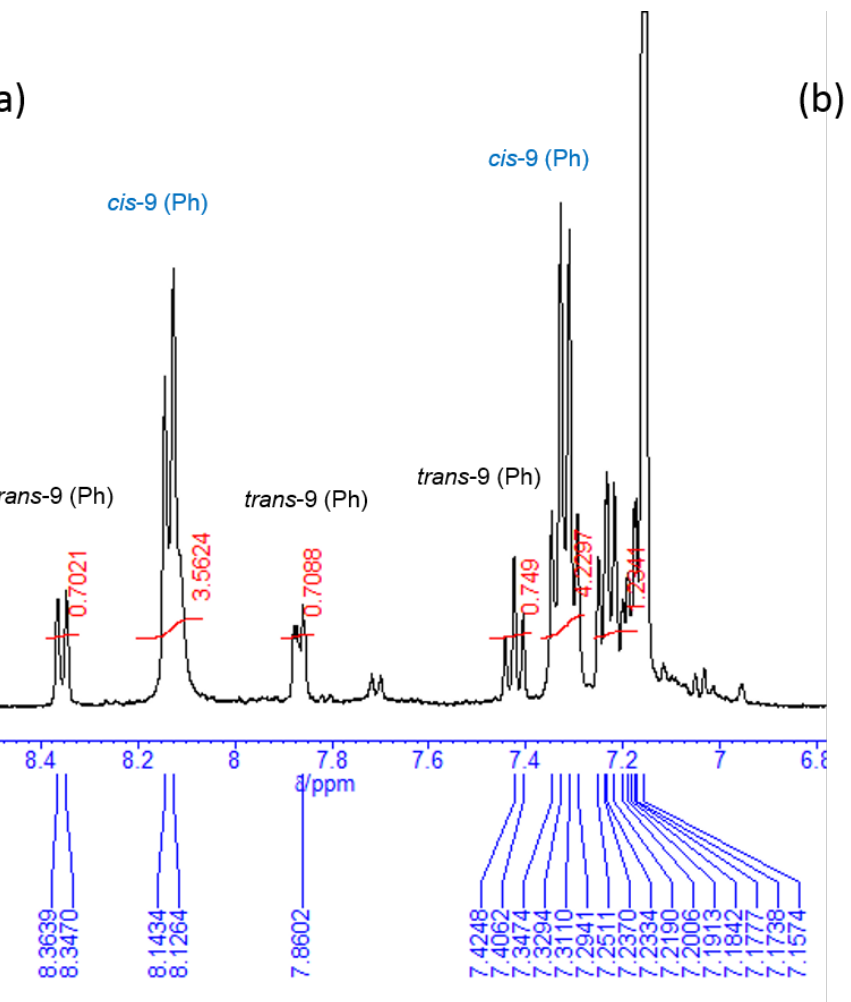

(b)

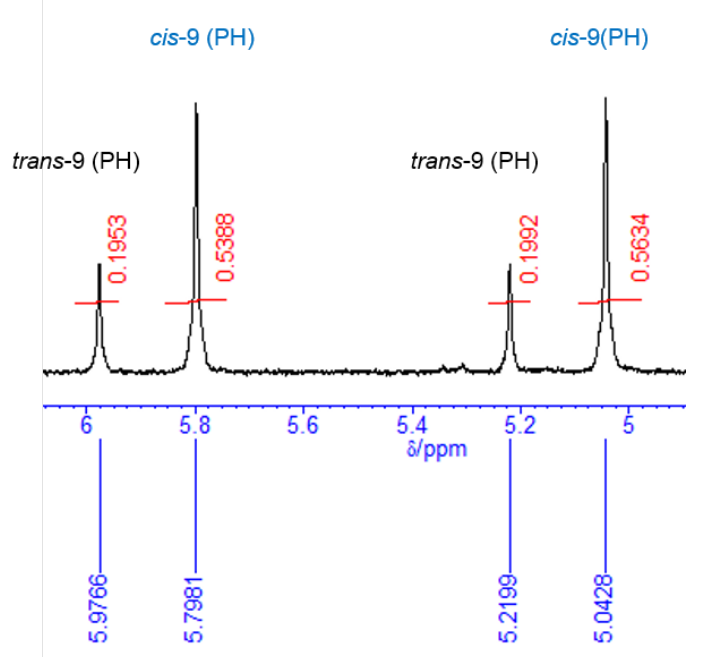

Figure S-45. Enlarged ${ }^{1} \mathrm{H}$ NMR spectrum of the mixture of cis- and trans-9 showing (a) $\mathrm{Ph}$ and (b) $\mathrm{PH}$ regions $\left(400 \mathrm{MHz}, \mathrm{C}_{6} \mathrm{D}_{6}, 25^{\circ} \mathrm{C}\right)$. 


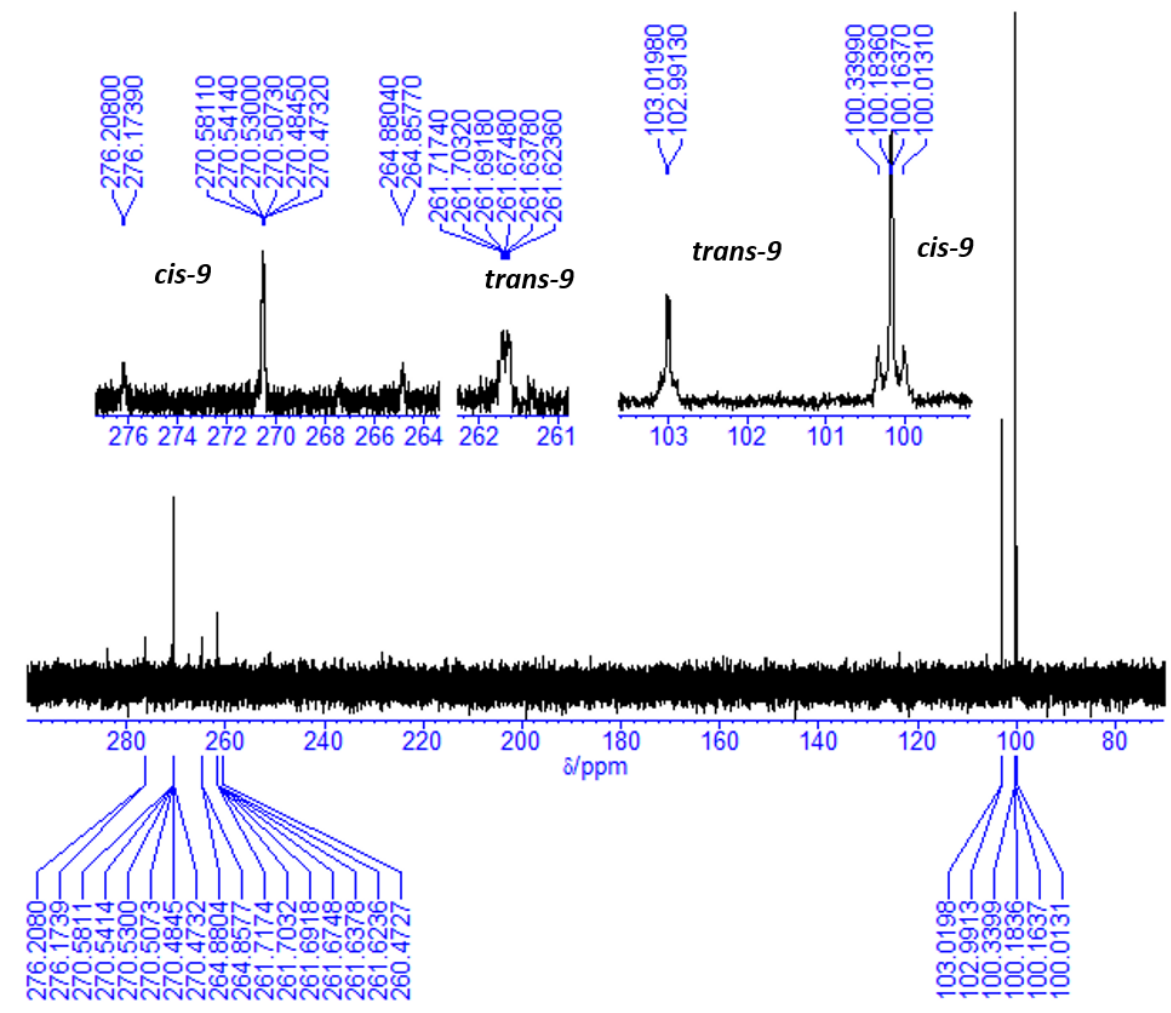

Figure S-46. ${ }^{31} \mathrm{P}\left\{{ }^{1} \mathrm{H}\right\}$ NMR spectrum of the mixture of cis- and trans-9 $\left(162 \mathrm{MHz}, \mathrm{C}_{6} \mathrm{D}_{6}, 25{ }^{\circ} \mathrm{C}\right)$. 
k. ${ }^{1} \mathrm{H},{ }^{13} \mathrm{C}\left\{{ }^{1} \mathrm{H}\right\}$, and ${ }^{31} \mathrm{P}\left\{{ }^{1} \mathrm{H}\right\} \mathrm{NMR}$ and IR spectra of $\left\{\mathrm{Cp} * \mathrm{Ru}(\mathrm{H})_{2}\right\}\left\{\mathrm{Cp} * \operatorname{Ru}\left(\mathrm{P}^{\mathrm{t}} \mathrm{Bu}_{2} \mathrm{H}\right)\right\} \operatorname{Pt}\left(\mu-\mathrm{P}^{\mathrm{t}} \mathrm{Bu}_{2}\right)\left(\mu-\eta^{2}-\right.$ $\left.\mathrm{SiEt}_{2}\right)(\mu-\mathrm{H})_{2}(\mathbf{1 0})$

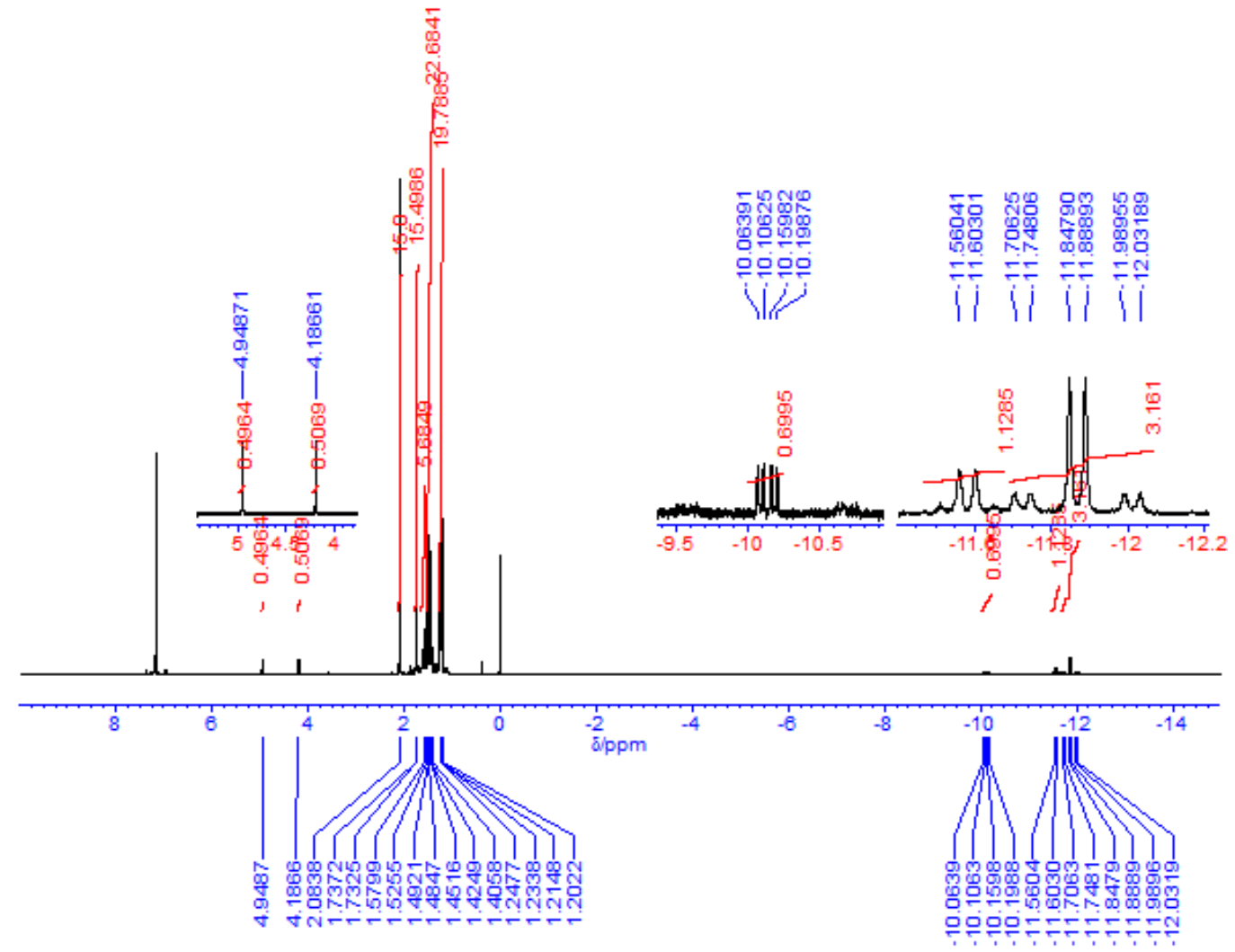

Figure S-47. ${ }^{1} \mathrm{H}$ NMR spectrum of the mixture of $\mathbf{1 0}\left(400 \mathrm{MHz}, \mathrm{C}_{6} \mathrm{D}_{6}, 25{ }^{\circ} \mathrm{C}\right)$.

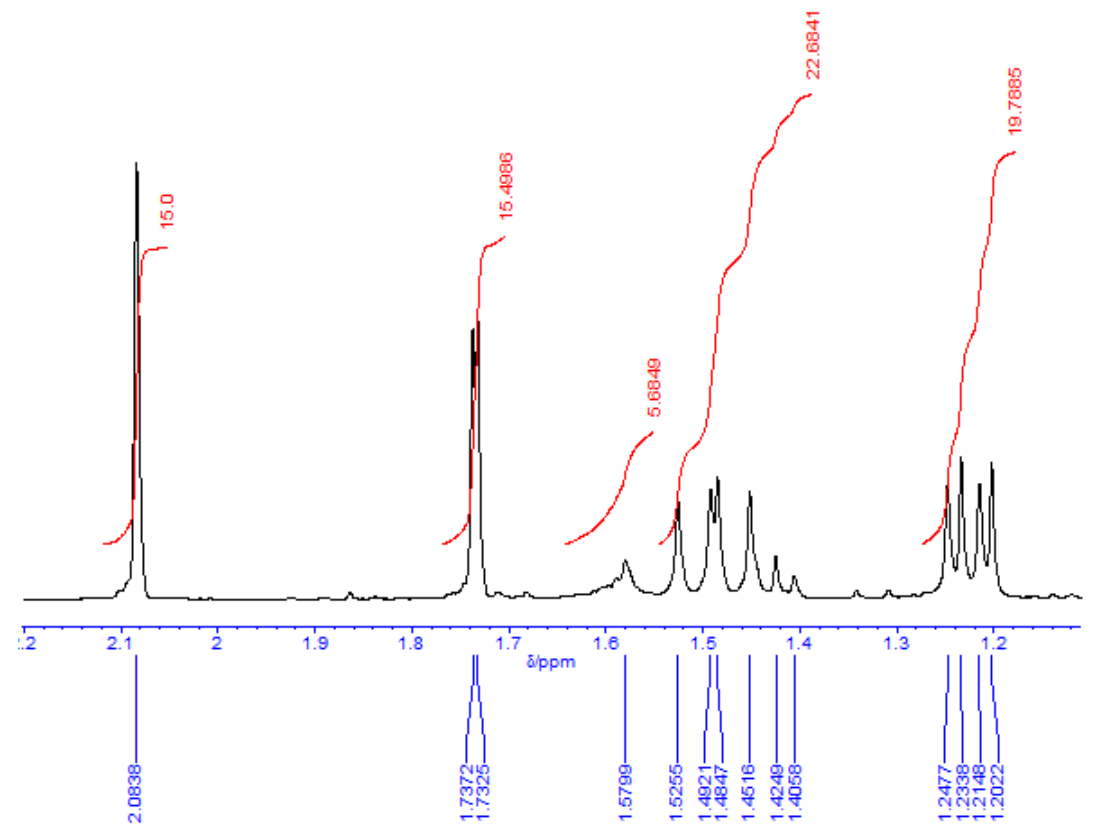

Figure S-48. Enlarged ${ }^{1} \mathrm{H}$ NMR spectrum of 10 showing $\mathrm{Cp} *$ region $\left(400 \mathrm{MHz}, \mathrm{C}_{6} \mathrm{D}_{6}, 25{ }^{\circ} \mathrm{C}\right)$. 


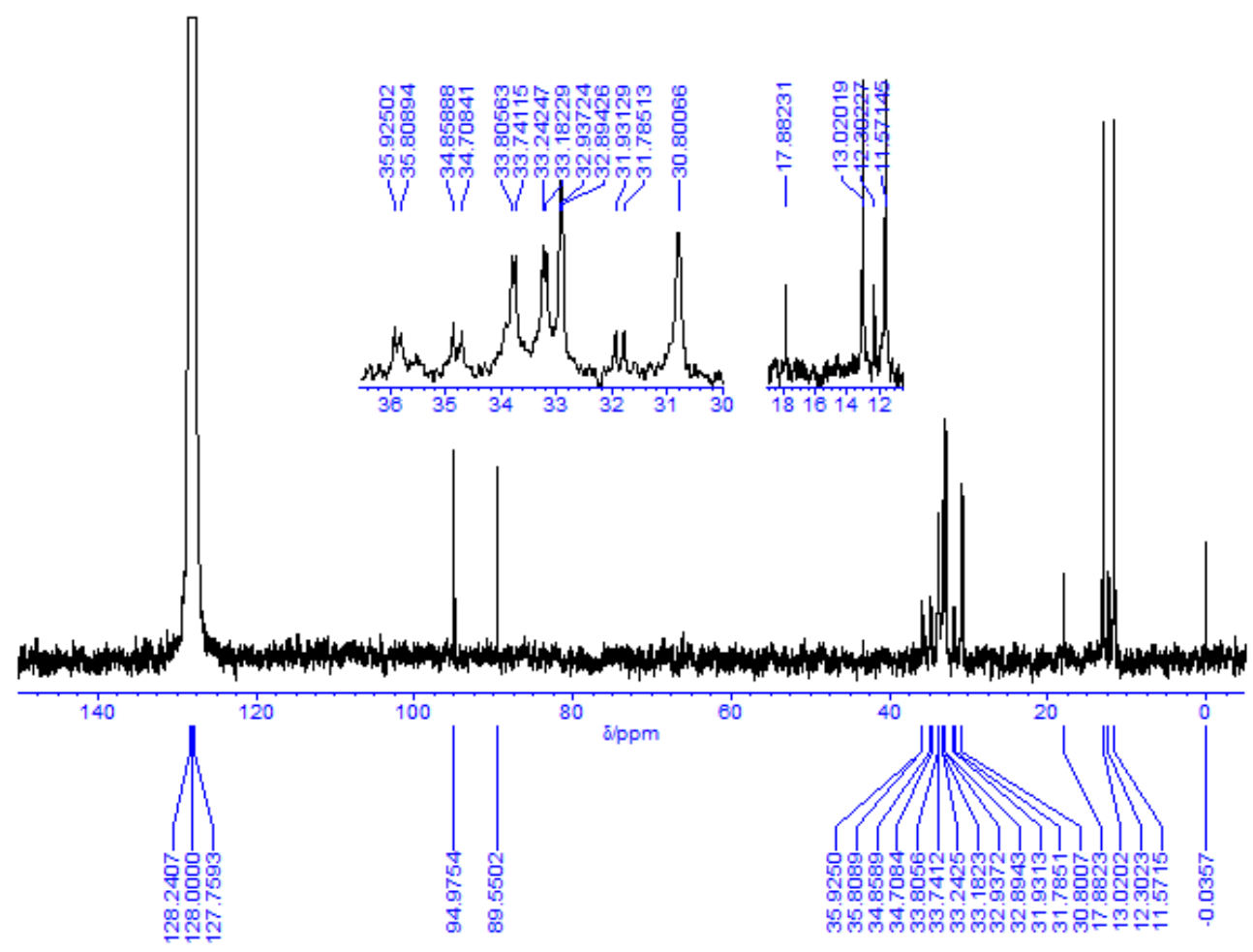

Figure S-49. ${ }^{13} \mathrm{C}\left\{{ }^{1} \mathrm{H}\right\}$ NMR spectrum of $\mathbf{1 0}\left(400 \mathrm{MHz}, \mathrm{C}_{6} \mathrm{D}_{6}, 25{ }^{\circ} \mathrm{C}\right)$.

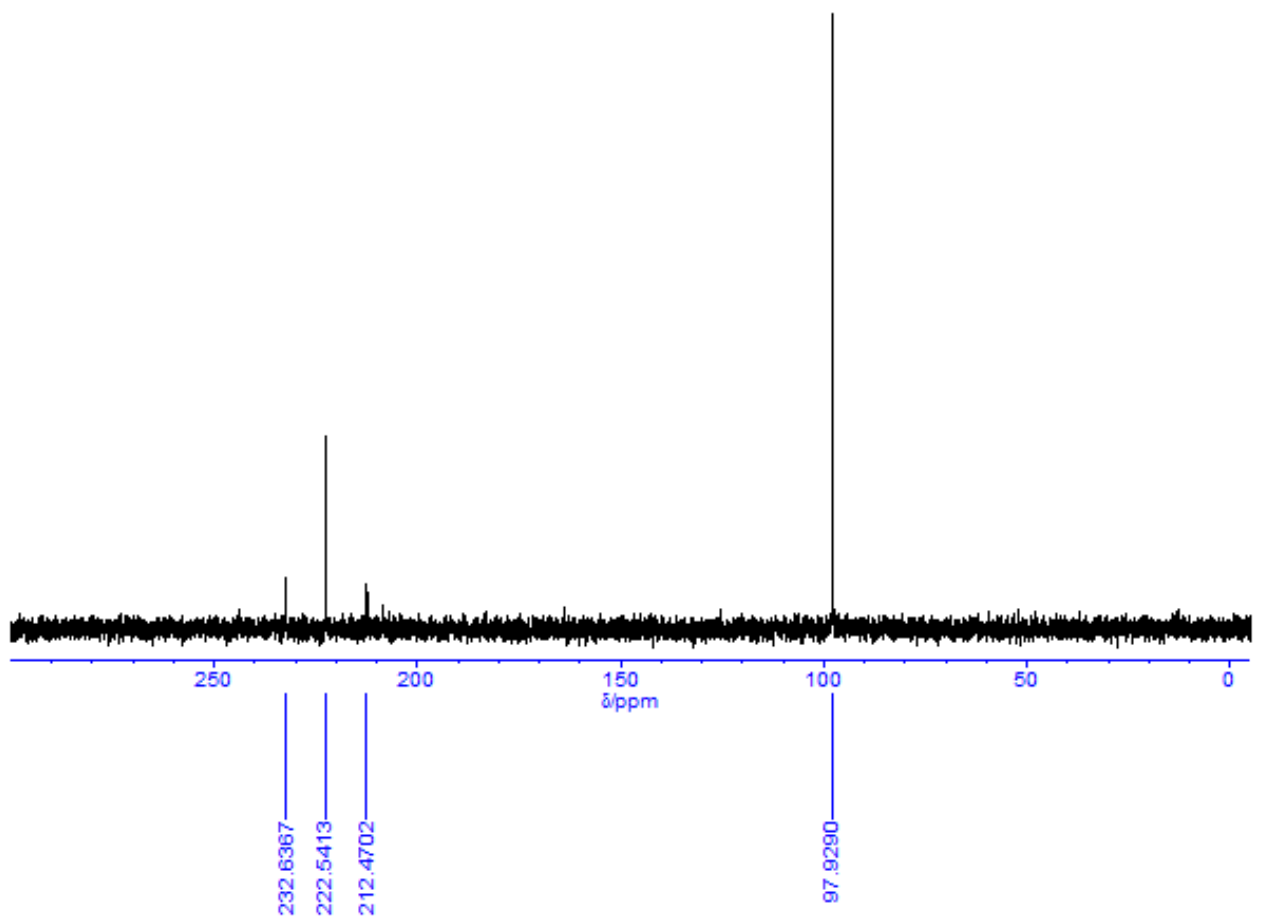

Figure S-50. ${ }^{31} \mathrm{P}\left\{{ }^{1} \mathrm{H}\right\}$ NMR spectrum of $\mathbf{1 0}\left(162 \mathrm{MHz}, \mathrm{C}_{6} \mathrm{D}_{6}, 25^{\circ} \mathrm{C}\right)$. 


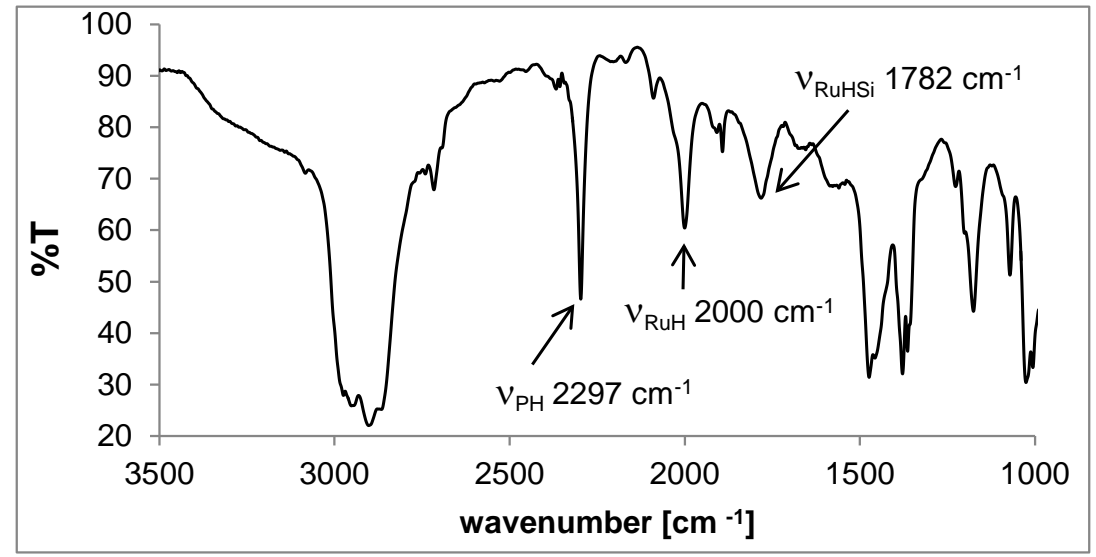

Figure S-51. IR spectrum of $\mathbf{1 0}\left(\mathrm{KBr}, \mathrm{cm}^{-1}\right)$ 
2. Crystallographic data for 2, 4, trans-5, trans-6, 8', cis-9, and 10.

Table S-4. Crystallographic Data for 2, 4, trans-5, trans-6, 8', cis-9, and 10.

\begin{tabular}{|c|c|c|c|c|}
\hline & 2 & 4 & trans -5 & trans-6 \\
\hline \multicolumn{5}{|l|}{ (a) Crystal Data } \\
\hline Empirical Formula & $\mathrm{C}_{36} \mathrm{H}_{72} \mathrm{P}_{2} \mathrm{PtRu}_{23}$ & $\mathrm{C}_{36} \mathrm{H}_{72} \mathrm{P}_{2} \mathrm{PtRu}_{23}$ & $\mathrm{C}_{38} \mathrm{H}_{68} \mathrm{O}_{2} \mathrm{P}_{2} \mathrm{PtRu}_{2}$ & $\mathrm{C}_{40} \mathrm{H}_{76} \mathrm{P}_{2} \mathrm{PtRu}_{2}$ \\
\hline Formula Weight & 964.10 & 964.10 & 1016.13 & 1016.18 \\
\hline Crystal Description & Platelet & Platelet & Platelet & Platelet \\
\hline Crystal Color & Green & Green & Orange & Orange \\
\hline Crystal size (mm) & $0.290 \times 0.244 \times 0.125$ & $0.227 \times 0.224 \times 0.185$ & $0.238 \times 0.182 \times 0.084$ & $0.190 \times 0.103 \times 0.026$ \\
\hline Crystallizing Solution & Toluene $\left(0^{\circ} \mathrm{C}\right)$ & Pentane $\left(-30^{\circ} \mathrm{C}\right)$ & Toluene $\left(-30^{\circ} \mathrm{C}\right)$ & $\operatorname{THF}\left(25^{\circ} \mathrm{C}\right)$ \\
\hline Crystal System & Triclinic & Triclinic & Triclinic & Triclinic \\
\hline Space Group & $P-1(\# 2)$ & $P-1(\# 2)$ & $P-1(\# 2)$ & $P-1(\# 2)$ \\
\hline \multirow[t]{6}{*}{ Lattice Parameters } & $a=8.5749(6) \AA$ & $a=9.8865(5) \AA$ & $a=8.7520(5) \AA$ & $a=8.6625(5) \AA$ \\
\hline & $b=10.4703(6) \AA$ & $b=11.0176(6) \AA$ & $b=10.7962(6) \AA$ & $b=10.8809(7) \AA$ \\
\hline & $c=12.9177(9) \AA$ & $c=18.7452(8) \AA$ & $c=12.7446(6) \AA$ & $c=12.8072(9) \AA$ \\
\hline & $\alpha=66.245(2)^{\circ}$ & $\alpha=79.389(2)^{\circ}$ & $\alpha=67.2630(10)^{\circ}$ & $\alpha=68.185(2)^{\circ}$ \\
\hline & $\beta=74.156(2)^{\circ}$ & $\beta=79.211(2)^{\circ}$ & $\beta=74.113(2)^{\circ}$ & $\beta=75.376(2)^{\circ}$ \\
\hline & $\gamma=68.998(2)^{\circ}$ & $\gamma=83.866(2)^{\circ}$ & $\gamma=69.112(2)^{\circ}$ & $\gamma=68.479(2)^{\circ}$ \\
\hline $\mathrm{V}\left(\AA^{3}\right)$ & 979.70(11) & $1965.89(17)$ & $1024.65(10)$ & $1033.10(11)$ \\
\hline$Z$ value & 1 & 2 & 1 & 1 \\
\hline$D_{\text {calc }}\left(\mathrm{g} / \mathrm{cm}^{3}\right)$ & 1.634 & 1.629 & 1.647 & 1.633 \\
\hline Measurement Temp & $-130^{\circ} \mathrm{C}$ & $-150^{\circ} \mathrm{C}$ & $-150^{\circ} \mathrm{C}$ & $-150^{\circ} \mathrm{C}$ \\
\hline$\mu(\operatorname{MoK} \alpha)\left(\mathrm{mm}^{-1}\right)$ & 4.426 & 4.411 & 4.240 & 4.202 \\
\hline \multicolumn{5}{|l|}{ (b) Intensity Measurements } \\
\hline Diffractometer & RAXIS-RAPID & RAXIS-RAPID & RAXIS-RAPID & RAXIS-RAPID \\
\hline Radiation & $\operatorname{MoK} \alpha$ & $\operatorname{MoK} \alpha$ & $\operatorname{MoK} \alpha$ & $\operatorname{MoK} \alpha$ \\
\hline Monochromator & Graphite & Graphite & Graphite & Graphite \\
\hline $2 \theta \max$ & $55^{\circ}$ & $55^{\circ}$ & $55^{\circ}$ & $55^{\circ}$ \\
\hline Reflections Collected & 9519 & 19560 & 10159 & 10296 \\
\hline Independent reflections & $4417\left(R_{\mathrm{int}}=0.0341\right)$ & $8956\left(R_{\mathrm{int}}=0.0496\right)$ & $4659\left(R_{\mathrm{int}}=0.0267\right)$ & $4695\left(R_{\mathrm{int}}=0.0346\right)$ \\
\hline Reflections Obsd. $(>2 \sigma)$ & 4186 & 8215 & 4393 & 4398 \\
\hline Abs. Correction type & Numerical & Numerical & Numerical & Numerical \\
\hline Abs. Transmission & 0.3601 (min.) & 0.5518 (min.), & 0.6032 (min.), & 0.6694 (min.), \\
\hline & 0.5434 (max.) & 0.7313(max.) & 0.7284(max.) & 0.8670(max.) \\
\hline \multicolumn{5}{|l|}{ (c) Refinement (Shelxl-97-2) } \\
\hline$R_{1}(I>2 \sigma(I))$ & 0.0256 & 0.0258 & 0.0285 & 0.0267 \\
\hline$w R_{2}(I>2 \sigma(I))$ & 0.0546 & 0.0545 & 0.0655 & 0.0613 \\
\hline$R_{1}$ (all data) & 0.0274 & 0.0296 & 0.0306 & 0.0291 \\
\hline$w R_{2}$ (all data) & 0.0559 & 0.0562 & 0.0670 & 0.0627 \\
\hline Data/Restraints/Parameters & 4417 / 0 / 210 & 8956 / 0 / 416 & 4659 / 0 / 220 & 4695 / 0 / 221 \\
\hline GOF & 1.130 & 1.043 & 1.090 & 1.075 \\
\hline $\begin{array}{r}\text { Largest diff. peak and hole } \\
\left(\text { (e. } \AA^{-3}\right)\end{array}$ & 1.368 and -1.886 & 1.426 and -1.224 & 2.484 and -1.276 & 1.683 and -1.329 \\
\hline
\end{tabular}


Table S-4 (continued). Crystallographic Data for 2, 4, trans-5, trans-6, 8' , cis-9, and 10.

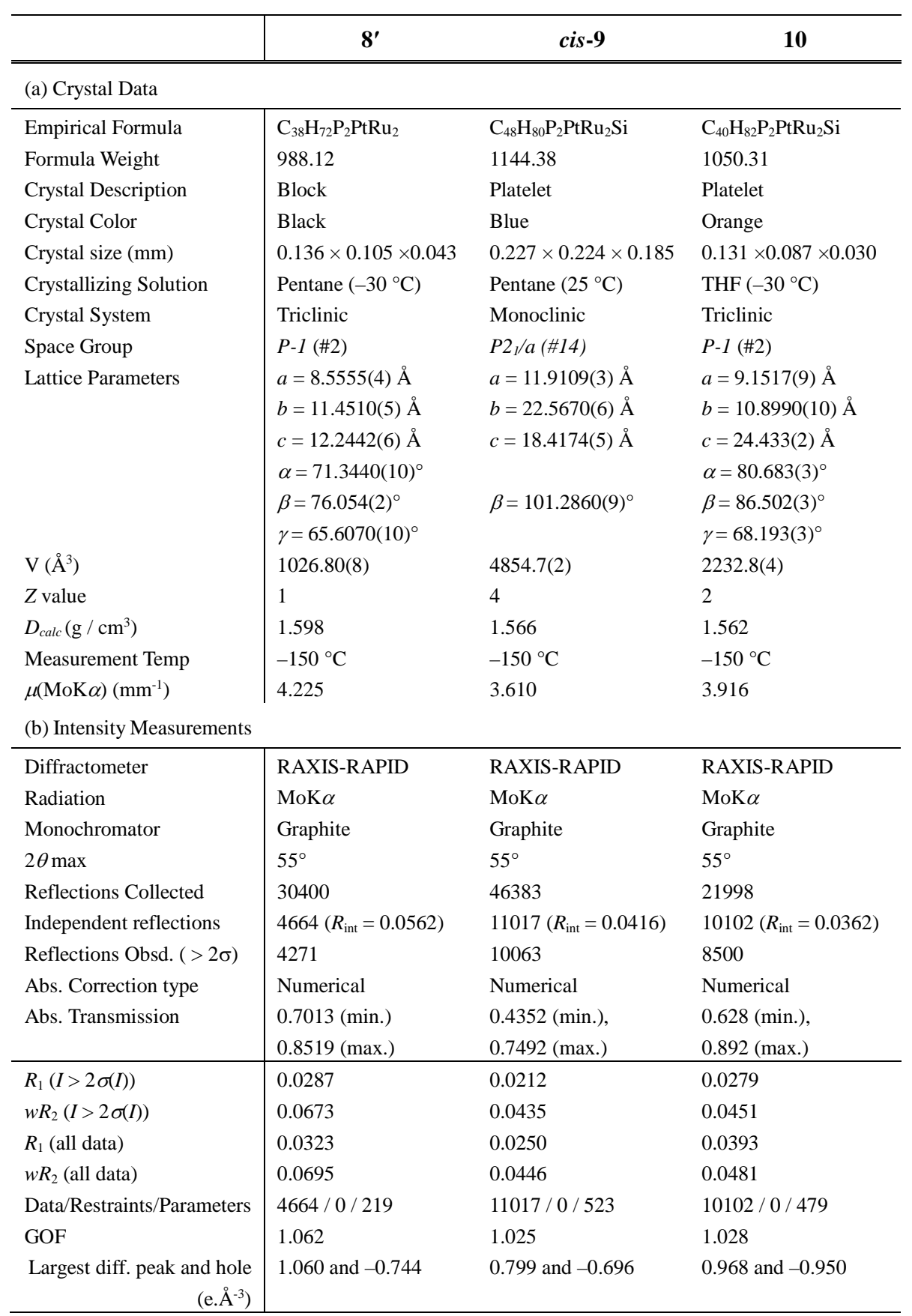




\section{Results of the DFT calculations on 2, 4, and the possible isomer of 4 (A in Scheme 4)}

a. Results of the DFT calculation of 2 .

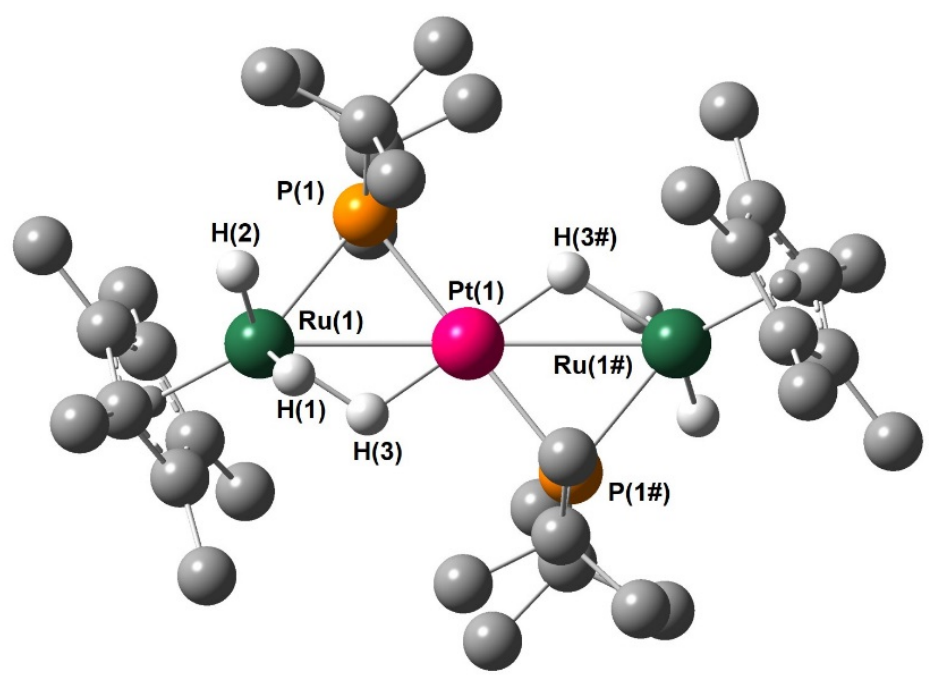

Figure S-52. Calculated structure for $\mathbf{2}$. Hydrogen atoms bonded to the carbon atoms were omitted for clarity.

Table S-5. Selected geometric parameters for the calculated structure for $\mathbf{2}$.

\begin{tabular}{|c|c|c|c|c|c|}
\hline & calcd. & \multicolumn{2}{|l|}{ cf. 2 (exp.) } & calcd. & cf. 2 (exp.) \\
\hline \multicolumn{6}{|l|}{ (a) bond lengths $(\AA)$} \\
\hline $\operatorname{Pt}(1)-\operatorname{Ru}(1)$ & 2.92451 & $2.8701(3)$ & $\mathrm{Pt}(1)-\mathrm{P}(1)$ & 2.30931 & $2.2781(7)$ \\
\hline $\mathrm{Pt}(1)-\mathrm{H}(3)$ & 1.71935 & $1.63(4)$ & $\mathrm{Ru}(1)-\mathrm{P}(1)$ & 2.34938 & $2.3279(7)$ \\
\hline $\mathrm{Ru}(1)-\mathrm{H}(1)$ & 1.58458 & $1.54(5)$ & $\mathrm{Ru}(1)-\mathrm{H}(2)$ & 1.57796 & 1.64(5), \\
\hline $\mathrm{Ru}(1)-\mathrm{H}(3)$ & 1.81726 & $1.74(5)$ & & & \\
\hline \multicolumn{6}{|l|}{ (b) bond angles (deg) } \\
\hline $\mathrm{Ru}(1)-\operatorname{Pt}(1)-\mathrm{Ru}(1 \#)$ & 180.000 & 180 & $\mathrm{Ru}(1)-\mathrm{Pt}(1)-\mathrm{P}(1)$ & 51.729 & $52.236(18)$ \\
\hline Ru(1)-Pt(1)-P(1\#) & 128.271 & $127.763(18)$ & $\mathrm{Ru}(1)-\mathrm{Pt}(1)-\mathrm{H}(3)$ & 35.309 & $32.9(15)$ \\
\hline Ru(1)-Pt(1)-H(3\#) & 144.690 & $147.1(15)$ & $\mathrm{P}(1)-\mathrm{Pt}(1)-\mathrm{P}(1 \#)$ & 179.999 & 180 \\
\hline $\mathrm{P}(1)-\mathrm{Pt}(1)-\mathrm{H}(3)$ & 86.337 & $84.4(15)$ & $\mathrm{P}(1)-\mathrm{Pt}(1)-\mathrm{H}(3 \#)$ & 93.663 & $95.6(15)$ \\
\hline $\mathrm{Pt}(1)-\mathrm{Ru}(1)-\mathrm{P}(1)$ & 50.507 & $50.683(19)$ & $\operatorname{Pt}(1)-\mathrm{Ru}(1)-\mathrm{H}(3)$ & 33.152 & $30.6(13)$ \\
\hline $\mathrm{P}(1)-\mathrm{Ru}(1)-\mathrm{H}(3)$ & 83.002 & $80.6(13)$ & $\operatorname{Pt}(1)-\mathrm{P}(1)-\mathrm{Ru}(1)$ & 77.764 & $77.08(2)$ \\
\hline
\end{tabular}


Table S-6. Coordinates of calculated structure for $\mathbf{2}$.

\begin{tabular}{|c|c|c|c|c|c|c|c|}
\hline Atom & $\mathrm{X}$ & $\mathrm{Y}$ & $\mathrm{Z}$ & Atom & $\mathrm{X}$ & $\mathrm{Y}$ & $\mathrm{Z}$ \\
\hline $\mathrm{Pt}$ & 7.92711300 & 6.99733100 & 5.84424100 & $\mathrm{H}$ & 8.54195800 & 5.96849100 & 7.07697000 \\
\hline $\mathrm{Ru}$ & 8.48569400 & 6.77185300 & 8.70604400 & $\mathrm{Ru}$ & 7.36852200 & 7.22281300 & 2.98244000 \\
\hline $\mathrm{P}$ & 7.20092200 & 8.36729300 & 7.55560100 & $\mathrm{P}$ & 8.65332200 & 5.62738500 & 4.13288300 \\
\hline $\mathrm{C}$ & 8.27274700 & 6.49470500 & 10.88036700 & $\mathrm{C}$ & 7.58147400 & 7.49991500 & 0.80811700 \\
\hline $\mathrm{C}$ & 9.52562200 & 5.94997900 & 10.41294700 & $\mathrm{C}$ & 6.32860900 & 8.04467500 & 1.27552300 \\
\hline $\mathrm{C}$ & 9.22428300 & 4.86379400 & 9.52999800 & $\mathrm{C}$ & 6.62996500 & 9.13087500 & 2.15844500 \\
\hline C & 7.78675900 & 4.70946100 & 9.50399100 & $\mathrm{C}$ & 8.06749200 & 9.28517700 & 2.18446100 \\
\hline $\mathrm{C}$ & 7.21321500 & 5.67514500 & 10.36670700 & $\mathrm{C}$ & 8.64101900 & 8.31946300 & 1.32176400 \\
\hline $\mathrm{C}$ & 8.10311400 & 7.55684500 & 11.92815100 & $\mathrm{C}$ & 7.75109500 & 6.43775700 & -0.23965100 \\
\hline $\mathrm{H}$ & 8.95229700 & 8.24624900 & 11.93706100 & $\mathrm{H}$ & 6.90189900 & 5.74836900 & -0.24856300 \\
\hline $\mathrm{H}$ & 8.02166200 & 7.10865900 & 12.92745800 & $\mathrm{H}$ & 7.83256500 & 6.88593000 & -1.23896300 \\
\hline $\mathrm{H}$ & 7.19966200 & 8.14886400 & 11.74954600 & $\mathrm{H}$ & 8.65453400 & 5.84572400 & -0.06103000 \\
\hline $\mathrm{C}$ & 10.89141700 & 6.36877900 & 10.87492000 & $\mathrm{C}$ & 4.96280700 & 7.62589400 & 0.81355000 \\
\hline $\mathrm{H}$ & 10.92332800 & 7.43867200 & 11.10016600 & $\mathrm{H}$ & 4.93087900 & 6.55600000 & 0.58831300 \\
\hline $\mathrm{H}$ & 11.64735900 & 6.17246300 & 10.10944900 & $\mathrm{H}$ & 4.20686700 & 7.82222800 & 1.57901900 \\
\hline $\mathrm{H}$ & 11.17537100 & 5.82169600 & 11.78311900 & $\mathrm{H}$ & 4.67886400 & 8.17297500 & -0.09465300 \\
\hline $\mathrm{C}$ & 10.21827500 & 3.92821800 & 8.90473400 & $\mathrm{C}$ & 5.63598100 & 10.06649300 & 2.78366000 \\
\hline $\mathrm{H}$ & 9.86789700 & 3.55948300 & 7.93591200 & $\mathrm{H}$ & 5.98634800 & 10.43526200 & 3.75247100 \\
\hline $\mathrm{H}$ & 10.39787100 & 3.05825100 & 9.55005400 & $\mathrm{H}$ & 5.45641100 & 10.93643700 & 2.13830300 \\
\hline $\mathrm{H}$ & 11.17722200 & 4.42643700 & 8.73430400 & $\mathrm{H}$ & 4.67702200 & 9.56829800 & 2.95409200 \\
\hline $\mathrm{C}$ & 7.04437600 & 3.62180900 & 8.78246500 & C & 8.80989900 & 10.37282100 & 2.90597500 \\
\hline $\mathrm{H}$ & 7.59120700 & 3.28748700 & 7.89596000 & $\mathrm{H}$ & 8.26304300 & 10.70721300 & 3.79243800 \\
\hline $\mathrm{H}$ & 6.05704600 & 3.95853400 & 8.45048000 & $\mathrm{H}$ & 9.79719300 & 10.03605600 & 3.23802600 \\
\hline $\mathrm{H}$ & 6.90308700 & 2.75125000 & 9.43631200 & $\mathrm{H}$ & 8.95127000 & 11.24334300 & 2.25209800 \\
\hline $\mathrm{C}$ & 5.79266200 & 5.72043100 & 10.85002700 & $\mathrm{C}$ & 10.06156500 & 8.27415100 & 0.83842100 \\
\hline $\mathrm{H}$ & 5.38702000 & 6.73634800 & 10.86827500 & $\mathrm{H}$ & 10.46724400 & 7.25824500 & 0.82030900 \\
\hline $\mathrm{H}$ & 5.74717800 & 5.32977700 & 11.87530900 & $\mathrm{H}$ & 10.10701200 & 8.66466100 & -0.18691800 \\
\hline $\mathrm{H}$ & 5.13017000 & 5.10415200 & 10.23626900 & $\mathrm{H}$ & 10.72404800 & 8.89054000 & 1.45207900 \\
\hline $\mathrm{C}$ & 7.85160100 & 10.15183700 & 7.60512400 & $\mathrm{C}$ & 8.00267100 & 3.84282200 & 4.08335500 \\
\hline $\mathrm{C}$ & 7.92513200 & 10.69895600 & 9.03989900 & $\mathrm{C}$ & 7.92922500 & 3.29566000 & 2.64859100 \\
\hline $\mathrm{H}$ & 8.58405200 & 10.09197900 & 9.66911000 & $\mathrm{H}$ & 7.27031600 & 3.90259600 & 2.01933000 \\
\hline $\mathrm{H}$ & 6.94218600 & 10.73788900 & 9.52106800 & $\mathrm{H}$ & 8.91219300 & 3.25674000 & 2.16746700 \\
\hline $\mathrm{H}$ & 8.32565800 & 11.72191200 & 9.02012200 & $\mathrm{H}$ & 7.52872800 & 2.27269200 & 2.66838100 \\
\hline $\mathrm{C}$ & 9.26916200 & 10.14158800 & 7.00829900 & $\mathrm{C}$ & 6.58507800 & 3.85306200 & 4.68009900 \\
\hline $\mathrm{H}$ & 9.25558400 & 9.80860300 & 5.96385200 & $\mathrm{H}$ & 6.59858700 & 4.18610000 & 5.72452900 \\
\hline $\mathrm{H}$ & 9.94389500 & 9.48104500 & 7.55928100 & $\mathrm{H}$ & 5.91036300 & 4.51356300 & 4.12904200 \\
\hline $\mathrm{H}$ & 9.68050200 & 11.15982500 & 7.04452900 & $\mathrm{H}$ & 6.17376600 & 2.83481400 & 4.64389500 \\
\hline $\mathrm{C}$ & 7.01089100 & 11.12009600 & 6.76186300 & $\mathrm{C}$ & 8.84333400 & 2.87458100 & 4.92668100 \\
\hline $\mathrm{H}$ & 6.83307400 & 10.72950200 & 5.75353800 & $\mathrm{H}$ & 9.02118100 & 3.26523700 & 5.93497900 \\
\hline $\mathrm{H}$ & 7.55015600 & 12.07194800 & 6.66506800 & $\mathrm{H}$ & 8.30401600 & 1.92276600 & 5.02354800 \\
\hline $\mathrm{H}$ & 6.04448300 & 11.34346200 & 7.22425000 & $\mathrm{H}$ & 9.80972300 & 2.65112600 & 4.46429900 \\
\hline $\mathrm{C}$ & 5.30656600 & 8.35484500 & 7.68461100 & $\mathrm{C}$ & 10.54768400 & 5.63988300 & 4.00394500 \\
\hline $\mathrm{C}$ & 4.89649600 & 6.87364100 & 7.68568300 & $\mathrm{C}$ & 10.95771500 & 7.12110000 & 4.00286800 \\
\hline $\mathrm{H}$ & 5.39949800 & 6.31104800 & 8.47201800 & $\mathrm{H}$ & 10.45479500 & 7.68365500 & 3.21645700 \\
\hline $\mathrm{H}$ & 5.14770700 & 6.40249600 & 6.72759200 & $\mathrm{H}$ & 10.70637400 & 7.59227000 & 4.96091200 \\
\hline $\mathrm{H}$ & 3.81098900 & 6.79604200 & 7.83660500 & $\mathrm{H}$ & 12.04324000 & 7.19872600 & 3.85207700 \\
\hline $\mathrm{C}$ & 4.80775100 & 9.03360100 & 8.96694000 & $\mathrm{C}$ & 11.04658100 & 4.96109600 & 2.72166100 \\
\hline $\mathrm{H}$ & 5.32920200 & 8.65766000 & 9.85546200 & $\mathrm{H}$ & 10.52515800 & 5.33699000 & 1.83310200 \\
\hline $\mathrm{H}$ & 3.73314800 & 8.84578500 & 9.09817700 & $\mathrm{H}$ & 12.12118500 & 5.14894100 & 2.59046600 \\
\hline $\mathrm{H}$ & 4.94586100 & 10.12012600 & 8.93202000 & $\mathrm{H}$ & 10.90850500 & 3.87456700 & 2.75661200 \\
\hline $\mathrm{C}$ & 4.60754300 & 8.97940100 & 6.46277900 & $\mathrm{C}$ & 11.24667600 & 5.01540700 & 5.22583600 \\
\hline $\mathrm{H}$ & 5.00680500 & 8.56794200 & 5.52881500 & $\mathrm{H}$ & 10.84728800 & 5.42683100 & 6.15976200 \\
\hline $\mathrm{H}$ & 4.68678400 & 10.06733900 & 6.42577000 & $\mathrm{H}$ & 11.16755600 & 3.92746100 & 5.26285300 \\
\hline $\mathrm{H}$ & 3.53701100 & 8.73524300 & 6.50904200 & $\mathrm{H}$ & 12.31718400 & 5.25968600 & 5.17965800 \\
\hline $\mathrm{H}$ & 9.88447800 & 7.13202300 & 8.05445500 & $\mathrm{H}$ & 5.96974200 & 6.86267000 & 3.63405600 \\
\hline \multirow[t]{2}{*}{$\mathrm{H}$} & 9.08488600 & 8.18365800 & 9.07717900 & $\mathrm{H}$ & 6.76927700 & 5.81102800 & 2.61132700 \\
\hline & & & & $\mathrm{H}$ & 7.31227400 & 8.02618500 & 4.61151400 \\
\hline
\end{tabular}


b. Results of the DFT calculation of 4 .

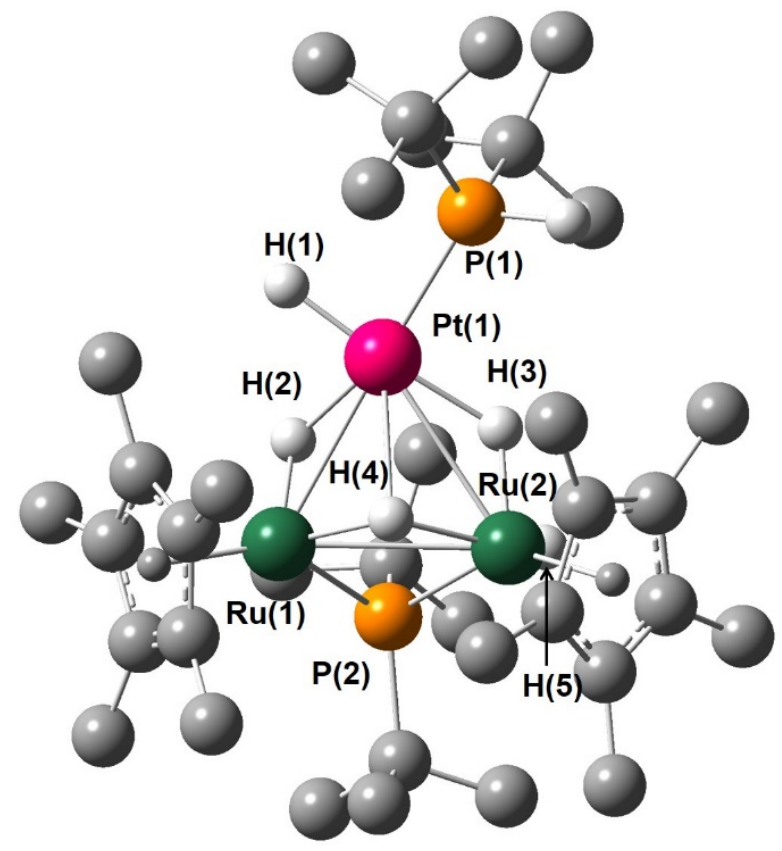

Figure S-53. Calculated structure for 4. Hydrogen atoms bonded to the carbon atoms were omitted for clarity.

Table S-7. Selected geometric parameters for the calculated structure for 4.

\begin{tabular}{|c|c|c|c|c|c|}
\hline & calcd. & \multicolumn{2}{|l|}{ cf. 2 (exp.) } & calcd. & cf. 2 (exp.) \\
\hline \multicolumn{6}{|l|}{ (a) bond lengths $(\AA)$} \\
\hline $\operatorname{Pt}(1)-\operatorname{Ru}(1)$ & 2.82402 & 2.7483(3) & $\operatorname{Pt}(1)-\operatorname{Ru}(2)$ & 3.01209 & 2.9163(3) \\
\hline $\mathrm{Ru}(1)-\mathrm{Ru}(2)$ & 3.02356 & 2.9692(3) & $\operatorname{Pt}(1)-\mathrm{P}(1)$ & 2.27454 & $2.2158(8)$ \\
\hline $\mathrm{Pt}(1)-\mathrm{H}(1)$ & 1.57816 & $1.43(4)$ & $\mathrm{Pt}(1)-\mathrm{H}(2)$ & 1.79307 & $1.90(4)$ \\
\hline $\mathrm{Pt}(1)-\mathrm{H}(3)$ & 1.83758 & $1.78(4)$ & $\mathrm{Ru}(1)-\mathrm{P}(2)$ & 2.30668 & $2.2844(7)$ \\
\hline $\mathrm{Ru}(1)-\mathrm{H}(2)$ & 1.71977 & $1.60(4)$ & $\mathrm{Ru}(1)-\mathrm{H}(4)$ & 1.76080 & $1.61(4)$ \\
\hline $\mathrm{Ru}(2)-\mathrm{P}(2)$ & 2.39511 & $2.3614(7)$ & $\mathrm{Ru}(2)-\mathrm{H}(3)$ & 1.67989 & $1.69(4)$ \\
\hline $\mathrm{Ru}(2)-\mathrm{H}(4)$ & 1.80768 & $1.87(4)$ & $\mathrm{Ru}(2)-\mathrm{H}(5)$ & 1.59682 & $1.49(3)$ \\
\hline \multicolumn{6}{|l|}{ (b) bond angles (deg) } \\
\hline $\mathrm{Ru}(1)-\mathrm{Pt}(1)-\mathrm{Ru}(2)$ & & $63.142(7)$ & $\mathrm{Ru}(1)-\mathrm{Pt}(1)-\mathrm{P}(1)$ & & $165.440(19)$ \\
\hline $\mathrm{Ru}(2)-\mathrm{Pt}(1)-\mathrm{P}(1)$ & & 114.84(2) & $\operatorname{Pt}(1)-\operatorname{Ru}(1)-\mathrm{Ru}(2)$ & & 61.193(7) \\
\hline $\mathrm{Pt}(1)-\mathrm{Ru}(1)-\mathrm{P}(2)$ & & 89.12(2) & $\mathrm{Ru}(2)-\mathrm{Ru}(1)-\mathrm{P}(2)$ & & $51.429(19)$ \\
\hline $\operatorname{Pt}(1)-R u(2)-R u(1)$ & & $55.665(7)$ & $\mathrm{Pt}(1)-\mathrm{Ru}(2)-\mathrm{P}(2)$ & & 83.737(18) \\
\hline $\mathrm{Ru}(1)-\mathrm{Ru}(2)-\mathrm{P}(2)$ & & 49.140(18) & $\mathrm{Ru}(1)-\mathrm{P}(2)-\mathrm{Ru}(2)$ & & 79.43(2) \\
\hline
\end{tabular}


Table S-8. Coordinates of calculated structure for $\mathbf{4}$.

\begin{tabular}{|c|c|c|c|c|c|c|c|}
\hline Atom & $\mathrm{X}$ & $\mathrm{Y}$ & $\mathrm{Z}$ & Atom & $\mathrm{X}$ & $\mathrm{Y}$ & $\mathrm{Z}$ \\
\hline $\mathrm{Pt}$ & 5.01383300 & 5.20412800 & 12.62116100 & $\mathrm{C}$ & 4.89853800 & 5.79425000 & 9.11696300 \\
\hline $\mathrm{Ru}$ & 5.97026500 & 7.28988700 & 14.26734900 & $\mathrm{H}$ & 5.96524800 & 5.54726300 & 9.04862000 \\
\hline $\mathrm{Ru}$ & 7.70941900 & 4.84174100 & 13.91545500 & $\mathrm{H}$ & 4.76962300 & 6.49520000 & 9.94749600 \\
\hline $\mathrm{P}$ & 4.60268100 & 3.75096400 & 10.92034100 & $\mathrm{H}$ & 4.60917600 & 6.29232900 & 8.18223200 \\
\hline $\mathrm{P}$ & 6.62918400 & 5.74809300 & 15.85147300 & $\mathrm{C}$ & 2.56062700 & 4.95061400 & 9.37851600 \\
\hline $\mathrm{C}$ & 4.78552500 & 8.84673400 & 13.22410300 & $\mathrm{H}$ & 2.36185300 & 5.57644300 & 10.25598100 \\
\hline $\mathrm{C}$ & 6.15557000 & 9.05422600 & 12.91557200 & $\mathrm{H}$ & 1.88867600 & 4.08563700 & 9.40944900 \\
\hline $\mathrm{C}$ & 6.85284600 & 9.36038800 & 14.14317900 & $\mathrm{H}$ & 2.30484100 & 5.53323400 & 8.48421500 \\
\hline $\mathrm{C}$ & 5.89305400 & 9.32701400 & 15.20159600 & $\mathrm{C}$ & 4.26845800 & 3.62209700 & 8.09248300 \\
\hline $\mathrm{C}$ & 4.61958600 & 8.96897000 & 14.65076300 & $\mathrm{H}$ & 5.31714000 & 3.30875600 & 8.02228500 \\
\hline $\mathrm{C}$ & 3.66452800 & 8.71334900 & 12.23624300 & $\mathrm{H}$ & 4.02840400 & 4.17612000 & 7.17581000 \\
\hline $\mathrm{H}$ & 2.85261200 & 8.09412200 & 12.62634500 & $\mathrm{H}$ & 3.64501100 & 2.72541100 & 8.10538100 \\
\hline $\mathrm{H}$ & 4.00123900 & 8.26075600 & 11.29932400 & $\mathrm{C}$ & 3.53737800 & 2.29004900 & 11.43571100 \\
\hline $\mathrm{H}$ & 3.25548000 & 9.70723800 & 12.00686100 & $\mathrm{C}$ & 2.29585300 & 2.78138500 & 12.19372400 \\
\hline $\mathrm{C}$ & 6.73720800 & 9.11616000 & 11.53288200 & $\mathrm{H}$ & 2.57700400 & 3.39568700 & 13.05505100 \\
\hline $\mathrm{H}$ & 7.80975400 & 8.89888300 & 11.54169900 & $\mathrm{H}$ & 1.72654600 & 1.91427600 & 12.55337700 \\
\hline $\mathrm{H}$ & 6.60763000 & 10.11550800 & 11.09504800 & $\mathrm{H}$ & 1.63106000 & 3.37717100 & 11.55911300 \\
\hline $\mathrm{H}$ & 6.25730900 & 8.39077900 & 10.86738100 & $\mathrm{C}$ & 3.11197600 & 1.37848800 & 10.27917200 \\
\hline $\mathrm{C}$ & 8.24408600 & 9.92016600 & 14.21495600 & $\mathrm{H}$ & 2.39395000 & 1.86395800 & 9.61029200 \\
\hline $\mathrm{H}$ & 8.90247600 & 9.45637900 & 13.47419800 & $\mathrm{H}$ & 2.62102500 & 0.48682100 & 10.69015200 \\
\hline $\mathrm{H}$ & 8.70111900 & 9.77851600 & 15.19822200 & $\mathrm{H}$ & 3.96851100 & 1.03957500 & 9.68456900 \\
\hline $\mathrm{H}$ & 8.23218100 & 11.00007400 & 14.01153400 & $\mathrm{C}$ & 4.41381800 & 1.47229000 & 12.40125800 \\
\hline $\mathrm{C}$ & 6.08348600 & 9.84063900 & 16.59933900 & $\mathrm{H}$ & 4.76768400 & 2.08064500 & 13.24026200 \\
\hline $\mathrm{H}$ & 5.42818300 & 9.32651500 & 17.30907500 & $\mathrm{H}$ & 5.28688700 & 1.04524700 & 11.89195200 \\
\hline $\mathrm{H}$ & 5.82867600 & 10.90875300 & 16.63286600 & $\mathrm{H}$ & 3.82350000 & 0.64042500 & 12.80653900 \\
\hline $\mathrm{H}$ & 7.11239500 & 9.74123600 & 16.95495400 & $\mathrm{C}$ & 7.87432600 & 6.21126300 & 17.23015800 \\
\hline $\mathrm{C}$ & 3.30819500 & 8.96478200 & 15.38134900 & $\mathrm{C}$ & 8.73899800 & 5.02398000 & 17.69101400 \\
\hline $\mathrm{H}$ & 2.60313900 & 8.26442400 & 14.92232800 & $\mathrm{H}$ & 8.22721400 & 4.38075000 & 18.40858300 \\
\hline $\mathrm{H}$ & 2.84543800 & 9.96183700 & 15.37447600 & $\mathrm{H}$ & 9.64549300 & 5.40050000 & 18.18570800 \\
\hline $\mathrm{H}$ & 3.43494900 & 8.66184900 & 16.42572000 & $\mathrm{H}$ & 9.04165500 & 4.40354000 & 16.84398400 \\
\hline $\mathrm{C}$ & 8.82235900 & 3.41697600 & 12.69587000 & $\mathrm{C}$ & 8.79927000 & 7.26625500 & 16.61076800 \\
\hline C & 9.50341100 & 3.52817200 & 13.95629100 & $\mathrm{H}$ & 8.24857200 & 8.18307000 & 16.40687600 \\
\hline $\mathrm{C}$ & 10.03897600 & 4.85190900 & 14.06991500 & $\mathrm{H}$ & 9.22137400 & 6.92777200 & 15.66272700 \\
\hline $\mathrm{C}$ & 9.62289600 & 5.57771600 & 12.91943600 & $\mathrm{H}$ & 9.62042800 & 7.49631600 & 17.30401300 \\
\hline $\mathrm{C}$ & 8.88360700 & 4.69870400 & 12.05327900 & $\mathrm{C}$ & 7.22525600 & 6.85966300 & 18.46388800 \\
\hline $\mathrm{C}$ & 8.29385800 & 2.13939700 & 12.11191400 & $\mathrm{H}$ & 6.58699500 & 7.70403400 & 18.18827000 \\
\hline $\mathrm{H}$ & 7.79989100 & 1.52689100 & 12.87238600 & $\mathrm{H}$ & 8.01637300 & 7.24306600 & 19.12381700 \\
\hline $\mathrm{H}$ & 9.11027900 & 1.54868500 & 11.67595600 & $\mathrm{H}$ & 6.62745800 & 6.15931300 & 19.05296200 \\
\hline $\mathrm{H}$ & 7.56383500 & 2.33574200 & 11.32196200 & $\mathrm{C}$ & 5.28667700 & 4.66706700 & 16.71164900 \\
\hline $\mathrm{C}$ & 9.82323700 & 2.37914700 & 14.86869800 & $\mathrm{C}$ & 4.54220500 & 3.75717800 & 15.72490000 \\
\hline $\mathrm{H}$ & 9.03756700 & 1.61872100 & 14.84420400 & $\mathrm{H}$ & 5.19916600 & 2.98157600 & 15.31769200 \\
\hline $\mathrm{H}$ & 9.94092700 & 2.70426900 & 15.90629700 & $\mathrm{H}$ & 4.10710800 & 4.30761500 & 14.88722100 \\
\hline $\mathrm{H}$ & 10.76372700 & 1.90385200 & 14.55974000 & $\mathrm{H}$ & 3.72529700 & 3.25847900 & 16.26524600 \\
\hline $\mathrm{C}$ & 11.10389400 & 5.28013300 & 15.03790100 & $\mathrm{C}$ & 5.82776500 & 3.72613300 & 17.79983800 \\
\hline $\mathrm{H}$ & 10.90796400 & 4.95132900 & 16.06105100 & $\mathrm{H}$ & 6.20487000 & 4.25110600 & 18.67977800 \\
\hline $\mathrm{H}$ & 11.22739900 & 6.36620200 & 15.05489900 & $\mathrm{H}$ & 6.62234000 & 3.07669900 & 17.41298800 \\
\hline $\mathrm{H}$ & 12.06471700 & 4.84647300 & 14.72920800 & $\mathrm{H}$ & 5.01121800 & 3.07684100 & 18.14299000 \\
\hline C & 10.04946700 & 6.97298400 & 12.57676000 & $\mathrm{C}$ & 4.24258600 & 5.61948000 & 17.32225300 \\
\hline $\mathrm{H}$ & 9.34607000 & 7.44100900 & 11.88303800 & $\mathrm{H}$ & 4.67519800 & 6.31979000 & 18.04350800 \\
\hline $\mathrm{H}$ & 11.03837600 & 6.96141400 & 12.09922500 & $\mathrm{H}$ & 3.47308400 & 5.03502300 & 17.84595800 \\
\hline $\mathrm{H}$ & 10.11173500 & 7.60387300 & 13.46817400 & $\mathrm{H}$ & 3.75631600 & 6.20520000 & 16.53518200 \\
\hline $\mathrm{C}$ & 8.43485000 & 5.03468100 & 10.66109800 & $\mathrm{H}$ & 5.70570500 & 3.02481000 & 10.40371700 \\
\hline $\mathrm{H}$ & 7.96509200 & 6.02290100 & 10.62108800 & $\mathrm{H}$ & 3.68890600 & 5.91503700 & 12.14182900 \\
\hline $\mathrm{H}$ & 7.70041700 & 4.30957200 & 10.29892800 & $\mathrm{H}$ & 4.66242300 & 6.18938200 & 14.07748200 \\
\hline $\mathrm{H}$ & 9.28458200 & 5.02803600 & 9.96528800 & $\mathrm{H}$ & 6.32454700 & 4.11272500 & 13.30495800 \\
\hline \multirow[t]{2}{*}{$\mathrm{C}$} & 4.03510300 & 4.53481900 & 9.30587300 & $\mathrm{H}$ & 7.03768800 & 6.36657800 & 13.21448700 \\
\hline & & & & $\mathrm{H}$ & 7.19981900 & 3.75227100 & 14.96578100 \\
\hline
\end{tabular}


c. Results of the DFT calculation of the isomer of 4 (A in Scheme 2).

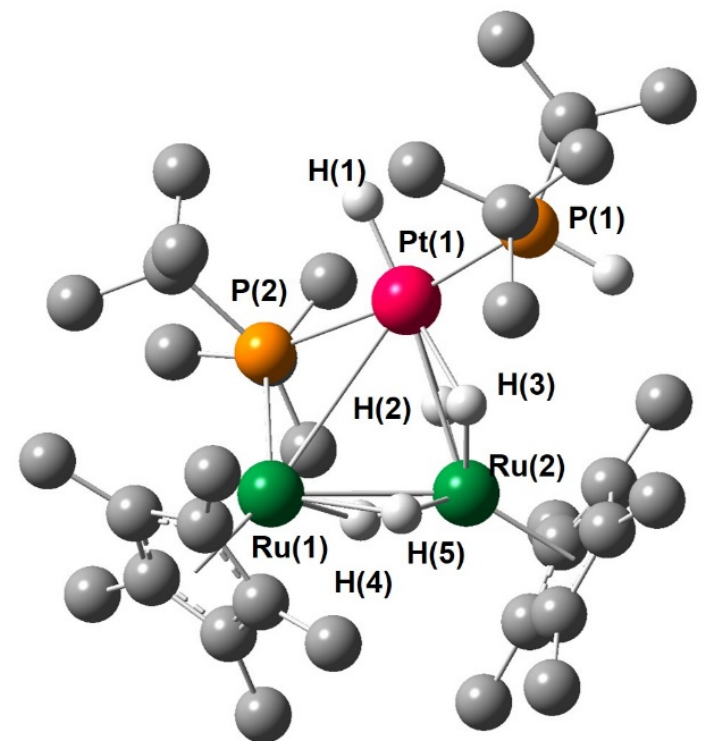

Figure S-54. Calculated structure for A. Hydrogen atoms bonded to the carbon atoms were omitted for clarity.

Table S-9. Selected geometric parameters for the calculated structure for A.

\begin{tabular}{|l|l|l|l|l|ll|}
\hline \multicolumn{9}{|l|}{} \\
\hline $\mathrm{Pt}(1)-\mathrm{Ru}(1)$ & 3.482 & $\mathrm{Pt}(1)-\mathrm{Ru}(2)$ & 2.961 & & $\mathrm{Ru}(1)-\mathrm{Ru}(2)$ & 2.938 \\
$\mathrm{Pt}(1)-\mathrm{P}(1)$ & 2.325 & $\mathrm{Pt}(1)-\mathrm{P}(2)$ & 2.366 & & $\mathrm{Pt}(1)-\mathrm{H}(1)$ & 1.581 \\
$\mathrm{Pt}(1)-\mathrm{H}(2)$ & 2.037 & $\mathrm{Pt}(1)-\mathrm{H}(3)$ & 1.929 & & $\mathrm{Ru}(1)-\mathrm{P}(2)$ & 2.441 \\
$\mathrm{Ru}(1)-\mathrm{H}(4)$ & 1.890 & $\mathrm{Ru}(1)-\mathrm{H}(5)$ & 2.027 & & $\mathrm{Ru}(2)-\mathrm{H}(2)$ & 1.632 \\
$\mathrm{Ru}(2)-\mathrm{H}(3)$ & 1.655 & & & & \\
\hline $\mathrm{Ru}(1)-\mathrm{Pt}(1)-\mathrm{Ru}(2)$ & 53.51 & $\mathrm{Ru}(1)-\mathrm{Pt}(1)-\mathrm{P}(2)$ & 44.43 & & $\mathrm{Ru}(2)-\mathrm{Pt}(1)-\mathrm{P}(1)$ & 104.40 \\
$\mathrm{P}(1)-\mathrm{Pt}(1)-\mathrm{P}(2)$ & 169.00 & $\mathrm{P}(1)-\mathrm{Pt}(1)-\mathrm{H}(1)$ & 85.16 & & $\mathrm{P}(2)-\mathrm{Pt}(1)-\mathrm{H}(1)$ & 85.65 \\
$\mathrm{Pt}(1)-\mathrm{Ru}(1)-\mathrm{Ru}(2)$ & 53.54 & $\mathrm{Pt}(1)-\mathrm{Ru}(1)-\mathrm{P}(2)$ & 42.74 & & $\mathrm{Ru}(2)-\mathrm{Ru}(1)-\mathrm{P}(2)$ & 84.48 \\
$\mathrm{Pt}(1)-\mathrm{Ru}(2)-\mathrm{Ru}(1)$ & 72.35 & $\mathrm{Pt}(1)-\mathrm{P}(2)-\mathrm{Ru}(1)$ & 92.84 & & \\
\hline
\end{tabular}


Table S-10. Coordinates of calculated structure for $\mathbf{A}$.

\begin{tabular}{|c|c|c|c|c|c|c|c|}
\hline Atom & $\mathrm{X}$ & $\mathrm{Y}$ & Z & Atom & $\mathrm{X}$ & $\mathrm{Y}$ & $\mathrm{Z}$ \\
\hline Pt & 4.64469200 & 4.43001300 & 12.91984800 & $\mathrm{C}$ & 5.07640500 & 5.15213500 & 9.20522800 \\
\hline $\mathrm{Ru}$ & 5.53146400 & 7.63775800 & 13.94381700 & $\mathrm{H}$ & 6.07277800 & 4.76887300 & 8.95220700 \\
\hline $\mathrm{Ru}$ & 7.39527500 & 5.48564300 & 13.22034200 & $\mathrm{H}$ & 5.17729000 & 5.81818300 & 10.06936700 \\
\hline $\mathrm{P}$ & 4.73305800 & 3.12412900 & 10.99836600 & $\mathrm{H}$ & 4.71995900 & 5.74468300 & 8.35250600 \\
\hline $\mathrm{P}$ & 4.12060800 & 5.82140700 & 14.76005500 & C & 2.70308000 & 4.63213700 & 9.76402400 \\
\hline $\mathrm{C}$ & 4.95636500 & 9.40885100 & 12.82657800 & $\mathrm{H}$ & 2.75707000 & 5.32551900 & 10.60917200 \\
\hline C & 6.38914000 & 9.40593700 & 12.96486200 & $\mathrm{H}$ & 1.94246300 & 3.87806700 & 9.99265500 \\
\hline $\mathrm{C}$ & 6.68216000 & 9.40734700 & 14.35954600 & $\mathrm{H}$ & 2.36666900 & 5.18869800 & 8.87939900 \\
\hline $\mathrm{C}$ & 5.43253500 & 9.43724400 & 15.08647200 & $\mathrm{C}$ & 3.99728600 & 3.12784200 & 8.22631000 \\
\hline C & 4.36686800 & 9.51150900 & 14.12365700 & $\mathrm{H}$ & 4.95211500 & 2.63430700 & 8.00972000 \\
\hline $\mathrm{C}$ & 4.21935700 & 9.47371800 & 11.52182700 & $\mathrm{H}$ & 3.74335800 & 3.75310600 & 7.36044800 \\
\hline $\mathrm{H}$ & 3.18487400 & 9.13343300 & 11.62993100 & $\mathrm{H}$ & 3.22099800 & 2.36033400 & 8.31073300 \\
\hline $\mathrm{H}$ & 4.69990000 & 8.84593800 & 10.76402000 & $\mathrm{C}$ & 4.04455600 & 1.38386300 & 11.18730900 \\
\hline $\mathrm{H}$ & 4.19620300 & 10.50357600 & 11.13978200 & $\mathrm{C}$ & 2.51116500 & 1.38546300 & 11.16334300 \\
\hline C & 7.35425500 & 9.50118800 & 11.82282400 & $\mathrm{H}$ & 2.09842400 & 2.09988200 & 11.88486400 \\
\hline $\mathrm{H}$ & 8.36982000 & 9.25018500 & 12.13545800 & $\mathrm{H}$ & 2.14496100 & 0.38654800 & 11.43295800 \\
\hline $\mathrm{H}$ & 7.36957000 & 10.52153300 & 11.41717600 & $\mathrm{H}$ & 2.11319900 & 1.62392200 & 10.17068700 \\
\hline $\mathrm{H}$ & 7.08217300 & 8.81844300 & 11.01037400 & $\mathrm{C}$ & 4.59084300 & 0.41583900 & 10.12758500 \\
\hline $\mathrm{C}$ & 8.03993600 & 9.45968700 & 14.99016400 & $\mathrm{H}$ & 4.26774900 & 0.66572200 & 9.11423600 \\
\hline $\mathrm{H}$ & 8.81367800 & 9.15047500 & 14.28237400 & $\mathrm{H}$ & 4.23279700 & -0.59832200 & 10.34742300 \\
\hline $\mathrm{H}$ & 8.10146600 & 8.79640000 & 15.85884100 & $\mathrm{H}$ & 5.68717200 & 0.38782700 & 10.13970900 \\
\hline $\mathrm{H}$ & 8.27203600 & 10.48011900 & 15.32243200 & $\mathrm{C}$ & 4.51871100 & 0.89361300 & 12.56680000 \\
\hline $\mathrm{C}$ & 5.30195400 & 9.58790300 & 16.57328000 & $\mathrm{H}$ & 4.13290400 & 1.52667700 & 13.37234000 \\
\hline $\mathrm{H}$ & 4.34379900 & 9.19793300 & 16.93153800 & $\mathrm{H}$ & 5.61358600 & 0.88779100 & 12.63802200 \\
\hline $\mathrm{H}$ & 5.37112000 & 10.64314500 & 16.87132300 & $\mathrm{H}$ & 4.16710900 & -0.13456300 & 12.72439400 \\
\hline $\mathrm{H}$ & 6.09354600 & 9.03939000 & 17.09413800 & $\mathrm{C}$ & 4.55765000 & 4.94921400 & 16.41890500 \\
\hline $\mathrm{C}$ & 2.95630300 & 9.96214900 & 14.37903000 & $\mathrm{C}$ & 4.32609000 & 3.43209000 & 16.31622400 \\
\hline $\mathrm{H}$ & 2.20344200 & 9.34382300 & 13.88366700 & $\mathrm{H}$ & 3.29862600 & 3.18457100 & 16.03188200 \\
\hline $\mathrm{H}$ & 2.84260900 & 10.98739500 & 14.00237300 & $\mathrm{H}$ & 4.53237800 & 2.96039400 & 17.28833200 \\
\hline $\mathrm{H}$ & 2.72253700 & 9.98285400 & 15.44613400 & $\mathrm{H}$ & 4.99143600 & 2.98861200 & 15.56717400 \\
\hline $\mathrm{C}$ & 8.70487500 & 3.78570100 & 12.77827400 & $\mathrm{C}$ & 6.02814500 & 5.17527400 & 16.80138400 \\
\hline $\mathrm{C}$ & 9.07167300 & 4.32156300 & 14.06195000 & $\mathrm{H}$ & 6.25181600 & 6.24146700 & 16.92469600 \\
\hline C & 9.56428900 & 5.65106200 & 13.85690200 & $\mathrm{H}$ & 6.71567700 & 4.77758500 & 16.05538600 \\
\hline $\mathrm{C}$ & 9.50354300 & 5.94231800 & 12.46113000 & $\mathrm{H}$ & 6.21973700 & 4.66792200 & 17.75797600 \\
\hline $\mathrm{C}$ & 8.95984100 & 4.79819200 & 11.79154800 & $\mathrm{C}$ & 3.73696700 & 5.49778600 & 17.59779400 \\
\hline $\mathrm{C}$ & 8.32491400 & 2.35615600 & 12.52447800 & $\mathrm{H}$ & 3.82227200 & 6.58714600 & 17.68374400 \\
\hline $\mathrm{H}$ & 7.65129600 & 1.98115400 & 13.30157300 & $\mathrm{H}$ & 4.12591000 & 5.06171000 & 18.52767600 \\
\hline $\mathrm{H}$ & 9.21755600 & 1.71672600 & 12.51054700 & $\mathrm{H}$ & 2.67875900 & 5.23461200 & 17.54141000 \\
\hline $\mathrm{H}$ & 7.81992900 & 2.23841200 & 11.56121500 & $\mathrm{C}$ & 2.23013000 & 6.13158200 & 14.78317200 \\
\hline $\mathrm{C}$ & 9.12580100 & 3.55846600 & 15.35352600 & $\mathrm{C}$ & 1.87819400 & 6.62905700 & 13.36944700 \\
\hline $\mathrm{H}$ & 8.33858500 & 2.79956800 & 15.40329500 & $\mathrm{H}$ & 1.98019700 & 5.82319500 & 12.63705500 \\
\hline $\mathrm{H}$ & 8.99809600 & 4.22092700 & 16.21538700 & $\mathrm{H}$ & 2.53370100 & 7.44520400 & 13.04984100 \\
\hline $\mathrm{H}$ & 10.09309600 & 3.04956400 & 15.46333900 & $\mathrm{H}$ & 0.83805500 & 6.98309700 & 13.34985200 \\
\hline $\mathrm{C}$ & 10.17520700 & 6.50416000 & 14.93005000 & $\mathrm{C}$ & 1.36522200 & 4.88872300 & 15.04562900 \\
\hline $\mathrm{H}$ & 9.57713200 & 6.48205500 & 15.84644600 & $\mathrm{H}$ & 1.48835000 & 4.49200400 & 16.05801400 \\
\hline $\mathrm{H}$ & 10.26552100 & 7.54732200 & 14.61761500 & $\mathrm{H}$ & 1.58469100 & 4.08520800 & 14.33532200 \\
\hline $\mathrm{H}$ & 11.18216100 & 6.14202800 & 15.17598700 & $\mathrm{H}$ & 0.30594700 & 5.16012300 & 14.93123100 \\
\hline $\mathrm{C}$ & 10.08109100 & 7.14505500 & 11.77562300 & $\mathrm{C}$ & 1.82979900 & 7.21792800 & 15.80440600 \\
\hline $\mathrm{H}$ & 9.47655100 & 7.45215100 & 10.91699900 & $\mathrm{H}$ & 1.59468200 & 6.79466500 & 16.78333100 \\
\hline $\mathrm{H}$ & 11.09319800 & 6.92377000 & 11.41100400 & $\mathrm{H}$ & 0.92982000 & 7.74517200 & 15.46061000 \\
\hline $\mathrm{H}$ & 10.15837400 & 7.99938600 & 12.45479200 & $\mathrm{H}$ & 2.61922300 & 7.95862400 & 15.94402900 \\
\hline $\mathrm{C}$ & 8.85395400 & 4.64052900 & 10.30209600 & $\mathrm{H}$ & 6.01184900 & 2.78486700 & 10.49332500 \\
\hline $\mathrm{H}$ & 8.51712400 & 5.56740900 & 9.82659300 & $\mathrm{H}$ & 3.15691900 & 3.91041200 & 13.04298100 \\
\hline $\mathrm{H}$ & 8.14023400 & 3.85450200 & 10.03553600 & $\mathrm{H}$ & 6.86260100 & 6.43477900 & 14.53706600 \\
\hline $\mathrm{H}$ & 9.82556600 & 4.37062100 & 9.86679100 & $\mathrm{H}$ & 6.22260900 & 5.17127200 & 12.09491100 \\
\hline \multirow[t]{2}{*}{$\mathrm{C}$} & 4.07744100 & 4.01223400 & 9.47590300 & $\mathrm{H}$ & 6.81738700 & 6.88064300 & 12.57238700 \\
\hline & & & & $\mathrm{H}$ & 6.36833400 & 4.48846800 & 14.00353300 \\
\hline
\end{tabular}

